Florida International University FIU Digital Commons

3-29-2013

\title{
Globalization and the Public Provision of Higher Education: Empirical Evidence from Selected Countries
}

Claudette Nyang'oro

Florida International University, cnyangoro@aol.com

DOI: $10.25148 /$ etd.FI13042508

Follow this and additional works at: https://digitalcommons.fiu.edu/etd

Part of the Higher Education Administration Commons, and the Other Education Commons

\section{Recommended Citation}

Nyang'oro, Claudette, "Globalization and the Public Provision of Higher Education: Empirical Evidence from Selected Countries" (2013). FIU Electronic Theses and Dissertations. 878.

https://digitalcommons.fiu.edu/etd/878 


\title{
FLORIDA INTERNATIONAL UNIVERSITY
}

Miami, Florida

\section{GLOBALIZATION AND THE PUBLIC PROVISION OF HIGHER EDUCATION: \\ EMPIRICAL EVIDENCE FROM SELECTED COUNTRIES}

\author{
A dissertation submitted in partial fulfillment of the \\ requirements for the degree of \\ DOCTOR OF EDUCATION \\ in \\ HIGHER EDUCATION \\ by \\ Claudette Nyang'oro
}




\section{To: Dean Delia Garcia,}

College of Education

This dissertation, written by Claudette Nyang'oro, and entitled Globalization and the Public Provision of Higher Education: Empirical Evidence from Selected Countries, having been approved in respect to style and intellectual content, is referred to you for judgment. We have read this dissertation and recommend that it be approved.

Benjamin Baez

$\begin{array}{r}\hline \text { Marvin Dawkins } \\ \hline \text { Janice Sandiford } \\ \hline \text { Kyle Perkins }\end{array}$

Date of Defense: March 29th, 2013

The dissertation of Claudette Nyang'oro is approved.

$\begin{array}{r}\begin{array}{r}\text { Dean Delia Garcia } \\ \text { College of Education }\end{array} \\ \hline \begin{array}{r}\text { Dean Lakshmi N. Reddi } \\ \text { University Graduate School }\end{array}\end{array}$

Florida International University, 2013 


\section{DEDICATION}

To Shari-Rose and Jon Jared 


\section{ACKNOWLEDGMENTS}

The completion of this dissertation would not have been realized if not for the support of several individuals who in one way or the other contributed to the final product. I would like to acknowledge the following persons. Firstly, Dr. Kingsley Banya, who served as my first supervisor and who guided me in the development of my topic and original proposal. Thanks to Dr. Roger Gonzalez, who took over the role of supervisor upon the departure of Dr. Banya. To the dissertation committee members who offered their advice and encouragement, Dr. Sandiford, Dr. Baez, Dr. Perkins, Dr. Dawkins and Dr. Clark. To Caprila Almeida of the Office of Graduate Studies at the College of Education who provided a light through the paper trail always in a cheerful manner. To Dr. Paulette Johnson of the Statistical Consulting Office who helped me navigate the data analysis process.

I would also like to that my family for their support in seeing the completion of this research. To my husband, Zak; my parents, Evelyn and Jonathan; my sisters, Marilyn, Judy, Helen and Kathleen; and my Uncle Elias, for their concern and encouragement in seeing the completion of this dissertation. As always any errors of omission and interpretation are solely the responsibility of the author. 


\title{
ABSTRACT OF THE DISSERTATION \\ GLOBALIZATION AND THE PUBLIC PROVISION OF HIGHER EDUCATION: EMPIRICAL EVIDENCE FROM SELECTED COUNTRIES
}

\author{
By \\ Claudette Nyang'oro \\ Florida International University, 2013 \\ Miami, Florida \\ Professor Roger Gonzalez, Major Professor
}

This research study was designed to examine the relationship between globalization as measured by the KOF index, its related forces (economic, political, cultural and technological) and the public provision of higher education. This study is important since globalization is increasingly being associated with changes in critical aspects of higher education. The public provision of education was measured by government expenditure and educational outcomes; that is participation, gender equity and attainment.

The study utilized a non-experimental quantitative research design. Data collected from secondary sources for 139 selected countries was analyzed. The countries were geographically distributed and included both developed and developing countries. The choice of countries for inclusion in the study was based on data availability. The data, which was sourced from international organizations such as the United Nations and the World Bank, were examined for different time periods using five year averages. The period covered was 1970 to 2009.

The relationship between globalization and the higher education variables was examined using cross sectional regression analysis while controlling for economic, 
political and demographic factors. The major findings of the study are as follows. For the two spending models, only one revealed a significant relationship between globalization and education with the $R^{2}$ s ranging from .222 to .448 over the period. This relationship was however negative indicating that as globalization increased, spending on higher education declined. However, for the education outcomes models, this relationship was not significant. For the sub-indices of globalization, only the political dimension showed significance as shown in the spending model. Political globalization was significant for six periods with $R^{2}$ s ranging from .31 to .52 .

The study concluded that the results are mixed for both the spending and outcome models. It also found no robust effects of globalization on government education provision. This finding is not surprising given the existing literature which sees mixed results on the social impact of globalization. 


\section{TABLE OF CONTENTS}

CHAPTER

PAGE

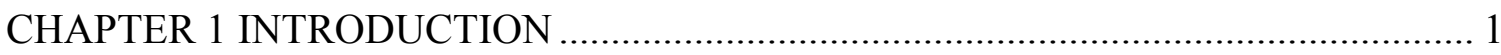

Background of the Study ……………................................................................. 1

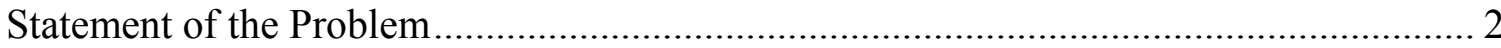

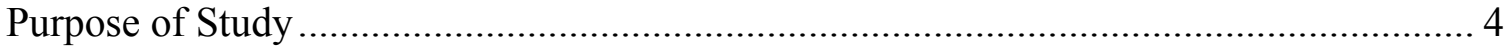

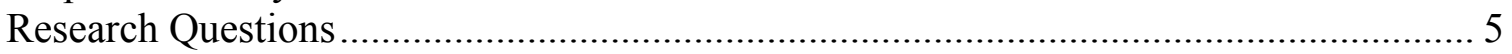

Significance of the Proposed Research...................................................................... 5

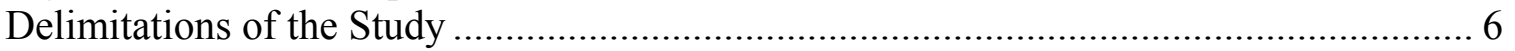

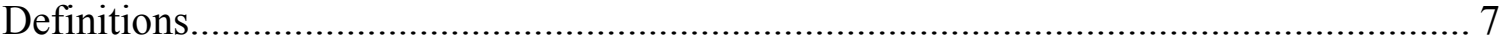

Proposed Theoretical and Analytical Framework of Analysis .......................................... 7

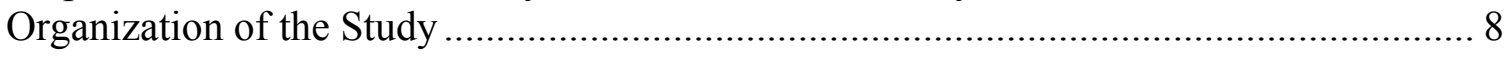

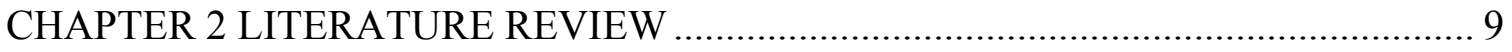

Globalization: Conceptualization, Dimensions

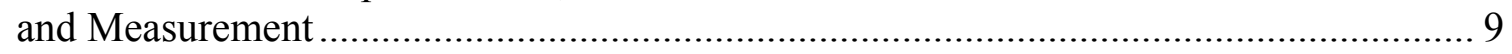

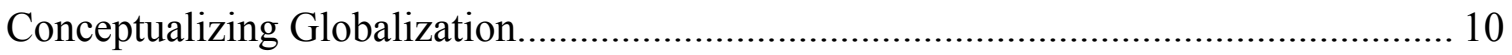

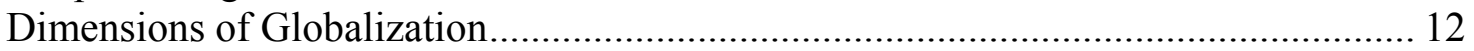

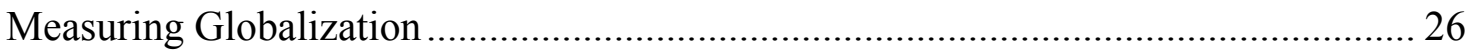

Globalization and Higher Education: Theoretical and Empirical Literature ..................... 29

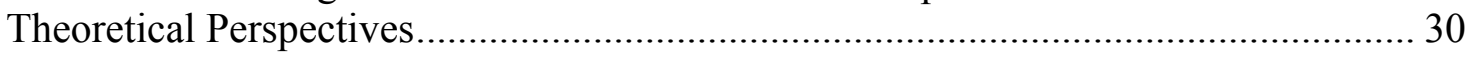

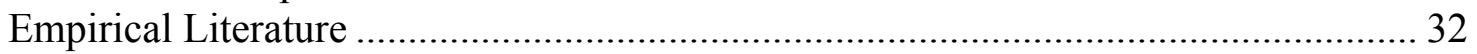

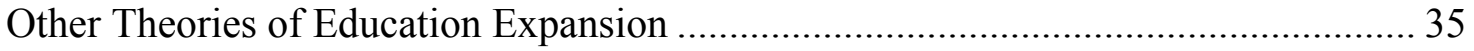

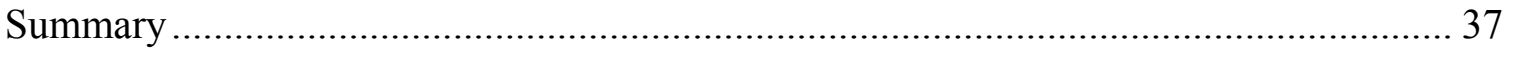

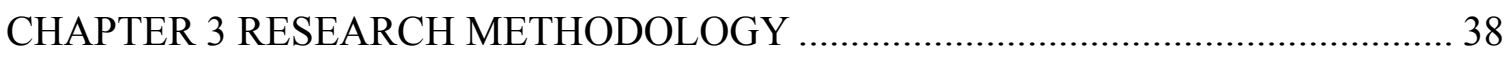

Research Questions and Hypotheses ...................................................................... 38

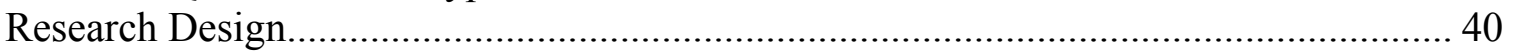

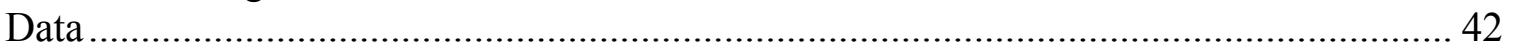

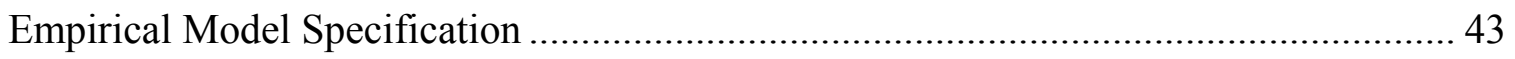

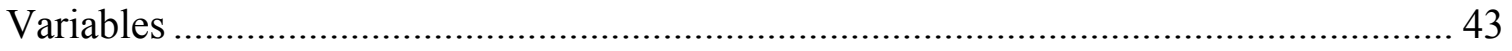

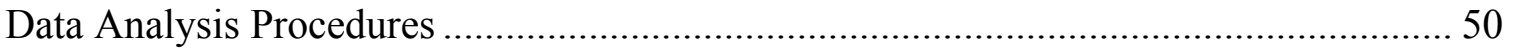

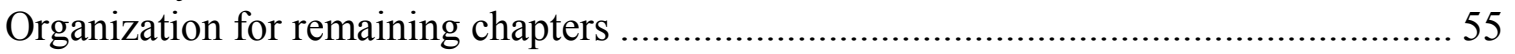

\section{CHAPTER 4 DATA ANALYSIS}

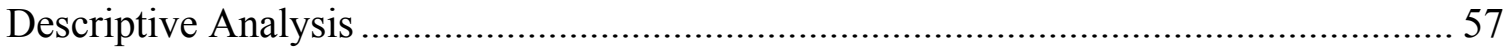

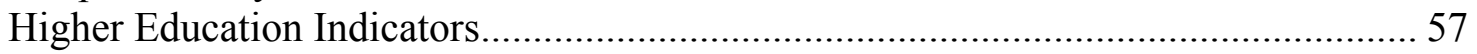

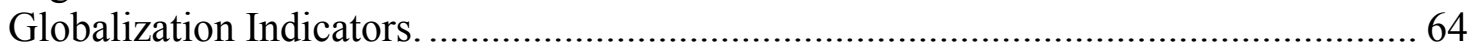

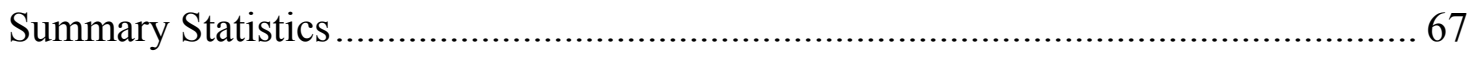

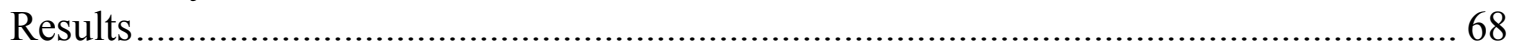

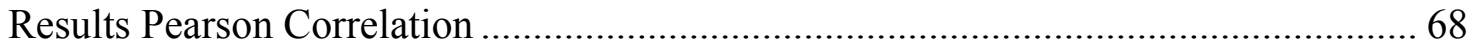




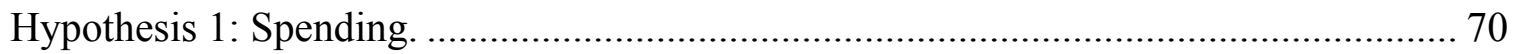

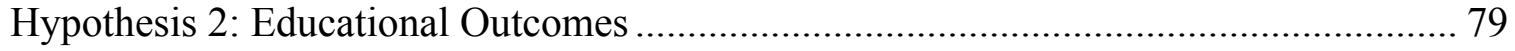

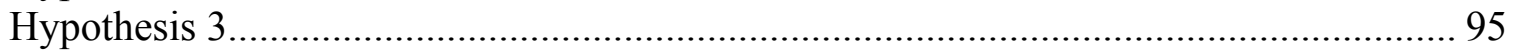

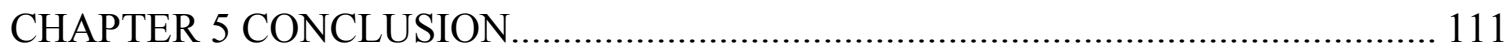

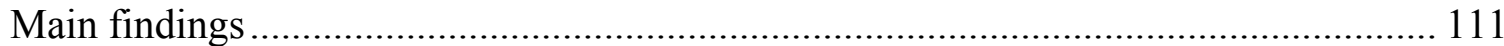

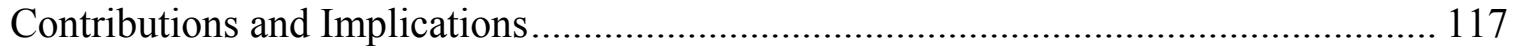

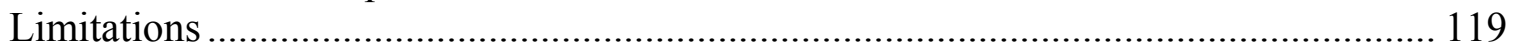

Implications and Directions for future research................................................ 120

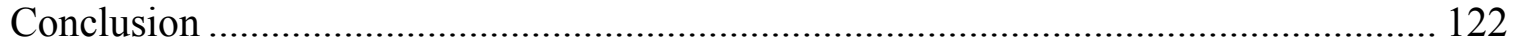

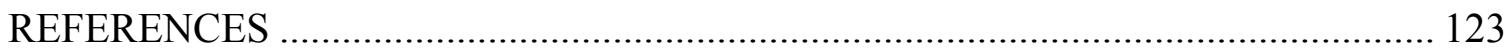

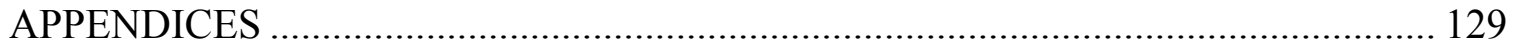




\section{LIST OF TABLES}

CHAPTER

PAGE

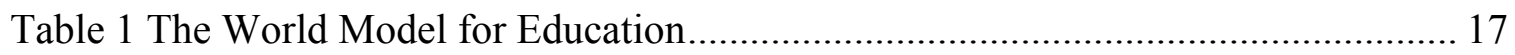

Table 2 Correlation matrices: globalization and higher education indicators .................. 69

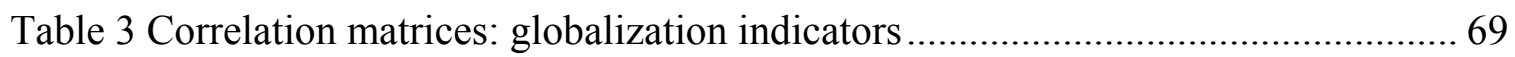

Table 4 Pearson Correlation and Bi-variate Regression Results: Higher education spending and KOF(Spending - SPENDGDPPCAP) .............................................. 71

Table 5 Pearson Correlation and Bi-variate Regression Results: Higher Education Spending and KOF (Spending - SPENDTOT) 72

Table 6 Bi-variate Regression Results: Higher Education Spending and Alternative Globalization Indicators (Spending- SPENDGDPPCAP)... 74

Table 7 Bi-variate Regression Results: Higher Education Spending and Alternative Globalization Indicators (Spending - SPENDTOR).

Table 8 Multiple Regression Results: Higher Education Spending and Globalization (KOF)(Spending - SPENDGDPPCAP).

Table 9 Multiple Regression Results: Higher Education Spending and Globalization (KOF) (Spending-SPENDTOT).

Table 10 Pearson Correlation and Bi-variate Regression Results: Higher Education Spending and KOF (Attainment - ATTAINP)

Table 11 Pearson Correlation and Bi-variate Regression Results: Higher Education Spending and KOF (Attainment- ATTAINY).

Table 12 Bi-variate Regression Results: Higher Education Attainment and Alternative Globalization Indicators (Attainment - ATTAINP) .....

Table 13 Bi-variate Regression Results: Higher Education Attainment and Alternative Globalization Indicators (Attainment - ATTAINY).

Table 14 Pearson Correlation and Bi-variate Regression Results: Higher Education

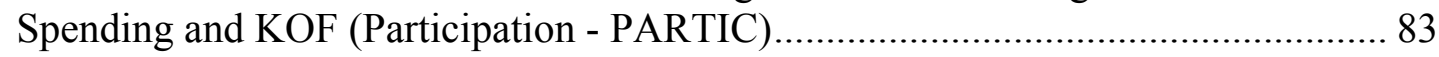

Table 15 Bi-variate Regression Results: Higher Education Attainment and Alternative Globalization Indicators (Participation - PARTIC). 
Table 16 Pearson Correlation and Bi-variate Regression Results: Higher Education Spending and KOF (Gender Equity - GENEQUC) ............................................... 85

Table 17 Pearson Correlation and Bi-variate Regression Results: Higher Education Gender Equity and KOF (Gender Equiaty - GENEQUGER) .............................. 86

Table 18 Bi-variate Regression Results: Higher Education Attainment and Alternative Globalization Indicators (Gender equity - GENEQUC)..................................... 87

Table 19 Bi-variate Regression Results: Higher Education Gender Equity and Alternative Globalization Indicators (Gender Equity -GENEQUGER) ................................. 87

Table 20 Multiple Regresssion Results: Higher Education Attainment (ATTAINP) and

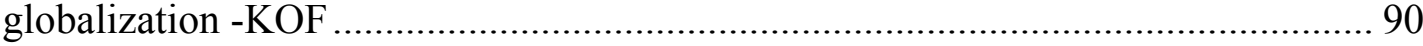

Table 21 Multiple Regression Results: Higher Education Attainment (ATTAINY) and

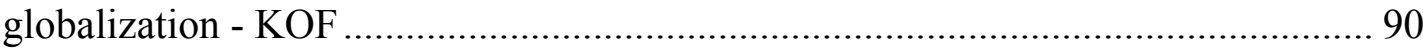

Table 22 Multiple Regression Results: Higher Education Particpation (PARTIC) and globalization - KOF

Table 23 Multiple Regression Results: Higher Education Equity (GENEQUC) and

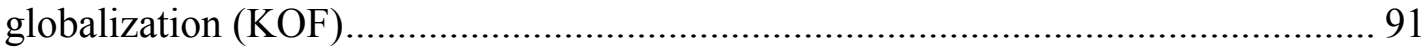

Table 24 Multiple Regression Results: Higher Education Equity (GENEQUGER) and

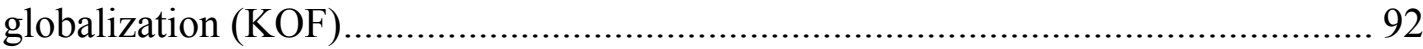

Table 25 Regression Results: Dimensions of Globalization and Spending on Higher

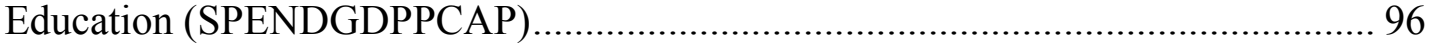

Table 26 Regression Results: Dimensions of Globalization, spending on higher education (SPENDGDPPCAP) and control variables

Table 27 Regression Results: Dimensions of globalization and spending on higher education (SPENDTOT). 98

Table 28 Regression Results: Dimensions of globalization, spending on higher education (SPENDTOT) and control variables.... 99

Table 29 Regression Results: Dimensions of Globalization and attainment in higher education (ATTAINP). 100

Table 30 Regression Results: Dimensions of Globalization, attainment in higher educlation (ATTAINP) and control variables 
Table 31 Regression Results: Dimensions of Globalization and attainment in Higher Education (ATTAINY)

Table 32 Regression Results: Dimensions of Globalization, attainment in higher education (ATTAINY) and control variables

Table 33 Regression Results: Dimensions of globalization and participation in Higher

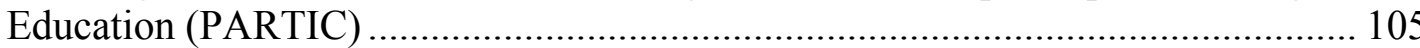

Table 34 Regression Results: Dimensions of Globalization, participation in higher Education (PARTIC) and Control Variables 106

Table 35 Regression Reuslt: Dimensions of Globalization and Gender Equity in Higher Education (GENEQUC)

Table 36 Regression Results: Dimensions of Globalization, gender equity in Higher Education (GENEQUC) and control Variables.................................................... 108

Table 37 Regression Results: Dimensions of Globalization and Gender Equity in Higher Education (GENEQUGER)

Table 38 Regression Results: Dimensions of Globalization, gender equity in higher education (GENEQUGER) and control variables ............................................ 110

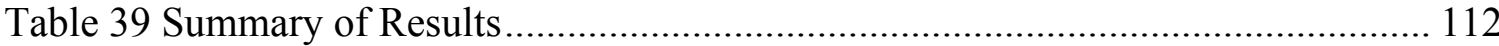




\section{LIST OF FIGURES}

FIGURE

PAGE

Figure 1. Time trend of higher education variable: SPENDGDPCAP. This figure shows the average development of higher education spending per student as a $\%$ of GDP per capita over the period for selected countries.

Figure 2. Time trend of higher education variable: SPENDTOT. This figure shows the average development of higher education expenditure as a percentage of total government spending over the period for selected countries.

Figure 3. Time trend of gender equity variable: GENEQUGER. This figure shows the average development of the ratio of females to males enrolled in higher education over the period for selected countries.

Figure 4.Time trend of gender equity variable: GENEQUC. This figure shows the average development over the period for selected countries.

Figure 5. Time trend of educational attainment variables for selected countries:

ATTAINP. This figure shows the average development in percentage of population 15 years and over attaining tertiary education over the period for selected countries.

Figure 6. Time trend of educational attainment variables for selected countries:

ATTAINY. This figure shows the average development in average years of tertiary education of the population education over the period for selected countries.

Figure 7. Time trend of participation variable for selected countries: PARTIC. This figure shows the average development in the gross enrollment ratio in higher education for selected countries over the period.

Figure 8. Time trend of the KOF globalization index and its dimensions for countries for which data are available in a given year. This figure show average development over the period. 65

Figure 9. Time trend of the TRADE globalization index for countries for which data are available in a given year. This figure show average development over the period... 66 
Figure 10. Time trend of the FDI globalization index for countries for which data are available in a given year. This figure show average development over the period... 66

Figure 11. Average development of globalization measures: FDI, TRADE, KOF $(1970=$ 100). 67 


\section{CHAPTER 1}

\section{INTRODUCTION}

Over the past two decades or so, many countries of the world, both developed and developing, have experienced major changes in their systems of higher education. These changes include, among others, a growing number of private providers (both local and international) who provide online programs in addition to traditional classroom settings and the changing role of government in the provision of higher education (Howe, 2005). Apart from local and regional influences, arguably, one of the major processes that have led to these changes is the highly contested process of globalization. Focusing on the macro level, this proposed research study entails an empirical examination of the relationship between globalization and the public provision of higher education in selected countries of the world. This is an empirical as opposed to non-empirical research study since it is based on objective evidence (quantitative data), not on subjective arguments.

\section{Background of the Study}

In the literature, globalization has been associated with far reaching effects on higher education. Welch (2001) for example notes that, "globalization processes are having substantial effects on education; indeed ... it is becoming increasingly difficult to understand education without reference to such processes. One arena where such effects are increasingly evident is that of higher education" (p. 478). The effects on higher education that have been associated with globalization however differ by a country's level of development. For small developing countries, for example it is clearly much more considerable since globalization has the potential to negatively affect the 
development of their already limited higher education systems. Within this context, Altbach (2004) argues that "any discussion of globalisation cannot avoid the deep inequalities that are part of the world system of higher education. Globalisation has added a new dimension to existing disparities in higher education" (p. 8).

A number of factors such as changes in public funding and a concomitant diversification in the source of university funding and a greater emphasis on accountability have been associated with globalization's effect on education. There has also been an increase in the number of foreign providers and a related thrust towards quality assurance (Al-Omari \& Obeidat, 2006; Howe, 2005; Mohamedbhai, 2002; Roberts, 2001).

\section{Statement of the Problem}

Globalization is increasingly being associated with changes in critical aspects of higher education including areas of provision, access and funding. However, there has been no consensus on what globalization is and how it affects education and higher education in particular (Deem, 2001; Fitzsimons, 2000; Forest, 2004; Mok, 2000). For the purposes of this paper, the definition adopted will be a combination of that provided by Altbach (2004) and Beerkens (2004). Altbach (2004) defines higher education globalization as "the broad economic, technological and scientific trends that directly affect higher education and are largely inevitable. Politics and culture are also a part of the new global realities" (p. 5). Adopting a definition that reflects Held et al.'s (1999) view of globalization, Beerkens (2004) defines globalization in higher education as, 
a process in which basic social arrangements within and around the university become disembedded from their national context due to the intensification of transnational flows of people, information and resources (p. 24).

Combining these two definitions, globalization, for the purposes of this paper, will be defined as a process involving the broad economic, political, technological and cultural trends that some have theorized directly affect higher education due to the intensification of flows of people, information and resources across national boundaries. This definition was chosen because it is presented within the context of higher education, is simply stated and captures the essence of the multifaceted role of globalization. The KOF index which captures the multidimensional nature of globalization is the measure of globalization used in this research. These dimensions of globalization and the measurement of globalization are discussed in Chapter 2 within the context of higher education.

Empirical research in this area is also limited (Enders, 2004; Vidovich, 2002; Yang, 2003). Research has tended to focus mainly on country groupings such as the Organisation for Economic Co-operation and Development (OECD), Latin America and Asia. Relatively little research has been done that compares the relationship for all countries. The absence of such research is critical since most studies adopt differing methodologies that makes comparison of globalization's relationship to higher education a difficult undertaking. Further, the relationship between globalization and higher education is likely to be different for developed as opposed to developing countries. This investigation of the relationship between globalization and higher education that focuses on the developed as well as developing countries is being undertaken to contribute to the 
relatively scarce empirical literature on this important topic, recognizing that the unique characteristics of both country groupings necessitate attention to this under-researched aspect of the study of globalization (Tikly, 2001).

Quantitative research of the relationship between globalization and education is also limited. While there have been a number of studies on the relationship between globalization on social spending (Avelino, Brown \& Hunter, 2005; Huber, Mustillo \& Stephens, 2004; Kaufman \& Segura-Ubiergo, 2001), there has been little focus on education and in particular, higher education. Studies of globalization's impact on education have also been largely restricted to spending. The outcomes of education in particular participation, attainment, and gender equity have largely been ignored in the literature.

The literature on globalization in higher education also tends to focus on educational globalization. Educational globalization examines the effect of globalization on educational practices, the marketing of educational services, the use of global informational technology such as e-learning and the organizational structure of educational institutions (Spring, 2009; Vaira, 2004). This is, however, only one facet of globalization's relationship with higher education. In order to assess globalization's “true relationship to educational change" (Carnoy, 1999, p. 15) this research focuses on how the process of globalization is related to the overall delivery of education.

\section{Purpose of Study}

The research study is designed to examine the relationship between globalization and the public provision of education, more specifically, on higher education. The main 
research problem that this study will address is to what extent the process of globalization is related to the provision of public higher education.

\section{Research Questions}

The central question guiding this study is: What is the relationship between the process of globalization and its related forces (economic, political, cultural and technological) and the public provision of higher education? To answer this central question, the study will focus on the following sub-research questions:

1. What is the relationship between globalization and public spending on higher education?

2. What is the relationship between globalization and other selected higher education outcomes (participation, attainment and gender equity)?

3. Which dimensions of globalization (economic, political, cultural, technological) account for unique variance when controlling for the other dimensions in the public provision of higher education?

\section{Significance of the Proposed Research}

My study of the relationship between globalization and the public provision of education in selected countries of the world will seek to contribute to the limited literature in this area by providing what, to my knowledge, is the first piece of statistical analysis on the topic that focuses not only on education but higher education in both developed and developing countries. This study is important as it will contribute to our general understanding of the relationship between globalization and higher education at the international level. It also has implications for future policy at the regional, national and perhaps even at the institutional level. The study will also address several limitations 
in the current research in the area by focusing on higher education in particular and on what dimensions (political, cultural, technological or economic) of globalization are most critical.

Empirical studies on the relationship between globalization and higher education has been inconclusive and several limitations of the current literature have been recognized. These include the importance of choosing an empirical methodology and data that are capable of providing robust evidence. This study will seek to make a contribution to the field by focusing on how the robustness of the results would be affected not only by the choice of globalization indicators but also by the different dimensions of globalization. The other major limitation in the literature that this research seeks to address is the choice of the dependent variable. As such, this research focuses not only on spending at the level of higher education but also on higher education outcomes such as gender equity, educational attainment and participation. The analytical framework that will be used in the study derives from the work of Levin (2001) and Tikly (2001) who focus on the forces of globalization and Chen's (2007) study of globalization and government provision of education in East Asia. Chen's study is largely based on Kaufman and Segura-Ubiergo (2001) research on globalization and social spending in Latin America.

\section{Delimitations of the Study}

This study is delimited to an analysis of secondary data collected from regional and international sources. This study is also delimited to the use of quantitative methods. While this approach has the advantage of providing statistical analysis which allows the 
testing of rival theories, the underlying causal mechanisms that link globalization to its effects on government provision of higher education cannot be effectively examined.

\section{Definitions}

The terms that are relevant to this study are defined below. Other terms which require definitions are explained as they are introduced.

Developed country. While there is no agreement on this term, it generally refers to a country that has a high level of economic growth and security. Examples include Canada, the United States and Germany.

Developing country. Countries in this group do not enjoy the same level of economic growth and security as that of developed countries. Examples include Haiti, Sierra Leone and Nepal.

Higher education. In the broadest sense, higher education refers to all post-secondary, post compulsory or tertiary education and as such includes further education, technical education and adult education. A more specific definition of higher education, however defines the concept more narrowly as education that leads to the award of a degree or diploma or similar designation. The criteria for entry are usually more rigorous than for other forms of post-secondary education. This study will apply the more specific definition of higher education.

\section{Proposed Theoretical and Analytical Framework of Analysis}

The theoretical and analytical framework proposed below seeks to link theoretical assumptions about globalization and higher education, to the empirical study of the impact of globalization on the public provision of higher education. 
The framework of analysis draws on globalization theory that views globalization as multidimensional. Thus while its economic dimension dominates literature on the subject, it is recognized that all of the other dimensions (cultural, political, technological) are intricately associated to some degree. The determinants of higher education expansion are also an important aspect of the analysis. The expansion of higher education is determined by a number of socio-economic and political factors such as economic development, population, and the political status of the country.

The public provision of higher education and its relation to globalization has largely been analyzed in the literature within the context of social spending (welfare state). Two major competing theories have emerged from these studies. They are the efficiency and the compensation hypothesis. However, these theories need to be placed within the context of globalization theory as well as theories concerning the expansion of education.

\section{Organization of the Study}

The remaining chapters of this proposal are the literature review, research methodology and results and conclusions. The literature review (Chapter 2) deals specifically with the concept of globalization and its dimensions (economic, political, cultural, and technological). Theories on globalization and government provision of higher education and their empirical application will also be examined. The research methodologies that will be adopted in the study are described in Chapter 3. This chapter's contents will detail the unit of analysis and research design that will be adopted as well as the data collection and analysis procedures. The results and conclusions will be explained in Chapters 4 and 5. 


\section{CHAPTER 2}

\section{LITERATURE REVIEW}

How has globalization affected the public provision of higher education? This literature review examines this question by focusing firstly on the definition, dimensions and measurement of globalization; followed by an examination of pertinent theoretical and empirical studies of its impact on higher education.

This chapter is divided into three main areas. The first major aspect presents a conceptualization of globalization and its dimensions (economic, political, social/cultural and technological) within the context of higher education. An analytical overview of the two contending hypotheses as well as other theories regarding the effect of globalization on the public provision of education as well as factors affecting the expansion of higher education will then be presented. An analytical framework for the study is also presented.

\section{Globalization: Conceptualization, Dimensions and Measurement}

Understanding the nature and process of globalization is a critical component of this research given the difficulty in defining the term. Gibbons (2002) for example notes that research on globalization and higher education is a difficult task to address "because globalisation is so complex a phenomenon that it is difficult to enter into its various processes and extract those which are likely to have the greatest impact on higher education" (p. 1). The complex nature of globalization is reflected in the interdisciplinary approach taken by many researchers in the field of higher education (McBurnie, 2001). 


\section{Conceptualizing Globalization}

While the use of the term 'globalization' gained currency in the 1990s, there is a lack of agreement of what constitutes globalization. Within the context of globalization and education, Tikly (2001) posits that:

A problem with many accounts of globalization and education is that they lack the precise definition of the term globalization. The lack of a precise definition is unfortunate given the slippery nature of the term and makes it difficult to assess the usefulness of the concept. (p. 152)

A sampling of definitions in the literature gives some insight into the problem of defining globalization. These definitions range in degree of complexity from the simplest to the highly complex and in focus from the singular to the multifaceted. Jones (1998) for example focusing on the economic dimension of globalization describes globalization simply as "economic integration, achieved in particular through the establishment of a global market place marked by free trade and regulation" (p. 143). This focus on the economic emphasizes the position of many researchers that globalization is primarily an economic phenomenon. This view is however being increasingly challenged by the recognition that other factors are perhaps of equal importance. Held, McGrew, Goldblatt, and Perraton's (1999) definition on the other hand is much more detailed and incorporates a greater range of factors in addition to the economic. They define globalization as "a process (or set of processes) which embodies a transformation in the spatial organization of social relations and transactions - assessed in terms of the extensity, intensity, velocity and impact - generating transcontinental or interregional flows and networks of activity, interaction and the exercise of power" (p. 16). This 
definition, with its focus on the globalization's geographical implications for social relations as well as political issues, provides a much more comprehensive view of the concept. This definition, incorporating as it does a wide range of dimensions, arguably captures the essence of what globalization entails.

Within the context of higher education, very little emphasis has been placed on precisely defining globalization in the literature (Lub, 2007; Tikly, 2001). One writer who has attempted such a definition is Altbach (2004), who defines higher education globalization as "the broad economic, technological and scientific trends that directly affect higher education and are largely inevitable. Politics and culture are also a part of the new global realities" (p. 5). Adopting a definition that reflects Held et al.'s (1999) view of globalization, another researcher (Beerkens, 2004) defines globalization in higher education as,

a process in which basic social arrangements within and around the university become disembedded from their national context due to the intensification of transnational flows of people, information and resources. (p. 24)

The sampling of the definitions presented gives some indication of the difficulty in defining globalization. From these few definitions several issues are evident. They include the fact that globalization is a very complex and complicated process, that it involves flows across national boundaries of capital, human and other resources and that it is not just an economic phenomenon but it has other dimensions which include, among others, the political, cultural, social, technological and scientific. What is clear is that while there are significant differences in the literature on what globalization is, partly due 
to differences in theoretical, ideological and disciplinary perspectives, there is growing consensus of globalization as a multifaceted ideological construct.

Whatever the understanding of globalization, it is generally accepted in the literature that globalization today has a number of unique features that clearly distinguishes it from previous forms of "globalization". Bourne (2004) identifies five features of present day globalization. These include (a) the rapid growth in world trade, (b) the expansion of the voluntary migration for work and pleasure, (c) greater complexities and openness in the financial markets, (d) the "rapid transference and adoption of institutional design and policies from some countries to others" (p. 68) and (e) the emergence of international regulatory standards. The emergence of this new phase of globalization has been attributed to a number of factors including the development of information and communications technology which has made intra country transactions less costly.

\section{Dimensions of Globalization}

Deriving from definition of globalization stated earlier (Chapter 1); this study will adopt a multi-dimensional (multidisciplinary) approach to the assessment of the impact of globalization on higher education. This approach has been adopted by a number of educational researchers including Levin (2001), McBurnie (2001), and Myers (2007). The main dimensions highlighted in the literature are the economic, the cultural, the technological and the political (Held, 2002; Waters, 1995; Zolo, 2007). These dimensions are discussed individually but it is recognized that none presents a complete picture of globalization and they are in fact all interrelated. 
Economic globalization. According to Levin (2001), the present form of globalization is largely understood as an economic theory. This conclusion is supported by other writers like McBurnie (2001), who argue that "the economic dimension is often held to be the key driver of globalization" (p. 13).

Robert Reich (as cited in Green, 1997), one of the leading proponents of the theory of economic globalization argues that technological advances have made concept of the national economy irrelevant. The development of a global market that has resulted from technological advances has made the movement of goods, capital, and other resources cheaper and faster than any time in history. This global market is facilitated by the growth of the transnational corporations which he characterized as having the ability to "relocate their operations without respect to national boundaries as economic advantage dictates, typically having multiple national bases and international workforces" (Green, p. 152). These transnational organizations not only operate in several national locations but produce goods and services that have no single national origin since the inputs may be sourced from a variety of countries. According to Reich (as cited in Green, 1997), the national economy will effectively disappear as the transnational become the dominant business enterprise usurping the role of the national corporations. With no control over these transnationals, governments will be forced to focus on what will then be the nation's primary assets, its human capital to generate national wealth.

The economic theory associated with the present globalization is neo-liberalism which is a theory advocating free competition and a self-regulatory market. This theory argues for limits on governments' involvement in the economy and promotes among other things the commodification of public goods. Policies advocated under this theory 
include economic liberalization, deregulation, privatization, finance capital investment, and labor flexibilization and export. International organizations such as the World Trade Organization and the International Monetary Fund as well as transnational corporations are often viewed as the major instruments of neoliberalism as their policies and practices tend to serve liberal capitalism (Lindio-McGovern, 2007).

Levin (2003) defines economic globalization in higher education as "the dominance of the market in organizational and social behavior and the interventionary role of the state through education, training and labor market practices" (p. 62).

Economic globalization is evident in higher education through the growing international trade in education and through the view that the economy of today is a knowledge economy demanding a work force whose credentials are acceptable worldwide. In this sense, education becomes a commodity to be traded as well an intellectual property (McBurnie, 2001).

The focus of much of the literature on economic globalization in higher education however has been on the practices of privatization, commodification and marketization of higher education (Clark, 1998; Levin, 2001; Myers, 2007; Slaughter \& Rhoades, 2004; Torres \& Schugurensky, 2002; Yoder, 2006). This study focuses not on the behavioral responses of institutions but on the impact of the global economy as it affects government revenues that in turn affect colleges through government funding alterations and policy initiatives.

Political dimension. There are two main approaches to political globalization (Bisley, 2007). The first approach views globalization as a political process, as a way of understanding and thinking about what is happening in the world. The second major 
approach and the approach which much of the literature on higher education focuses and by extension this paper, is on the role of the state, issues of national sovereignty and autonomy as well as political ideologies. Higher education is viewed as one of the major institutions that support the nation-state. There are two opposing views of the impact of globalization on the state, those who argue that the nation state is declining and being effectively replaced by a global polity and those who posit that the nation state is not in decline, but rather that its role has changed.

According to the declinist view of the state (Held, McGrew, Goldblatt \& Perraton, 1999), globalization has limited the state's ability to direct its own economic future and there is evidence that the powers of the state have been severely curtailed. Several factors in support of this view have been identified (Green, 1997). They include:

1. Lack of autonomy over defense and international relations. Increasingly for example regional and international agreements determine the state's ability to engage in defense activities. In terms of international relations the focus is increasingly towards international diplomacy where attempts at settling differences between countries emphasize negotiation before military confrontation.

2. Internally, the state is also at a cross roads and is losing both control and authority. Factors contributing to this loss of control include their inability to meet the demands for social services because of mounting cost of providing such services and their inability to provide adequate security services as reflected in an increased dependence on private security services. 
3. The growing number of regional and global organizations for example the European Union (EU), the North American Free Trade Association (NAFTA), United Nations (UN) and the International Monetary Fund (IMF) and the World Bank have effectively wrested sovereignty and autonomy away from states. The result of this as related to the regional and global organization and their impact on education can be seen in the world model of education supported by these agencies. The principal components of the model (since the 1980s) are presented in Table 1.

In this declinist view of the state, political globalization implies the erosion of these intangible bonds between state and people and the demotion of the state from a gemeinschaft [community] of communal solidarity to a mere gesellschaft [society] of pragmatic convenience. It also implies the promotion of some global community from gesellschaft to gemeinschaft (Mott, 2004, p. 113).

Political globalization is thus viewed as a growth in the role of a global polity and a decline in the role of the state. Mott (2004) further posits that "political globalization is the expansion of the exclusive perspectives of domestic and interstate politics to inclusive global politics. (It) appreciates global values and concerns, deflates commitments to narrow perspectives and local interests,....it involves not only the geographical expansion of political ideas into foreign polities but also the expansion of political activity from narrow perspectives to broader ones" (p. 114). 
Table 1

The World Model for Education.

\begin{tabular}{|c|c|}
\hline Items & Characteristics \\
\hline View of education & $\begin{array}{l}\text { Education is good for all. Consensus perspective. Education } \\
\text { contributes to development, economic growth, democracy, rational } \\
\text { human beings. Lifelong education socialization has become } \\
\text { education and learning that is monitored by the state }\end{array}$ \\
\hline Educational System & $\begin{array}{l}\text { Seven to nine year, compulsory. At least three years of secondary } \\
\text { education preferable }\end{array}$ \\
\hline Curriculum & $\begin{array}{l}\text { A national core curriculum; other parts flexible and adapted to } \\
\text { local conditions. Education for global competitiveness, education } \\
\text { for equality, education for empowerment, democracy, human } \\
\text { rights and citizenship, education and sexual education }\end{array}$ \\
\hline Financing & $\begin{array}{l}\text { Basic subsidies from the central state but major share from local } \\
\text { and medium levels. Private financing of education. }\end{array}$ \\
\hline Organization & $\begin{array}{l}\text { National skeleton, national framework. Decentralized bodies for } \\
\text { making of decisions within this framework. Local participation } \\
\text { community participation }\end{array}$ \\
\hline Regulation, control & $\begin{array}{l}\text { Surveillance and retroactive assessment by the state; choice } \\
\text { exerted by parents and pupils. }\end{array}$ \\
\hline Goals & $\begin{array}{l}\text { Effectiveness and efficiency rationale production of multi-skilled } \\
\text { people but at the same time instilling morals. }\end{array}$ \\
\hline
\end{tabular}

The argument that the state is in decline stems from the idea that economic globalization is undermining the power and efficacy of the state "reducing states to little more than pawns in the game of global capitalism" (Bisley, 2007, p. 56). As a result, "states have virtually no control over their economies and must follow the dictates and interests of global economic force (while) the power and pervasiveness of international organizations suck political authority and regulatory power away from the state" (Bisley, 2007, p. 56).

Bisley (2007) however counters this declinist interpretation of the impact of globalization on the state arguing rather that the role that the state has played has changed. His criticisms of this view focuses on the conceptual problems such as the 
extent to which globalization has in fact occurred and the analysis of the role of the state. Perhaps more importantly he argues that there has been little empirical evidence to support the claim that the state is in decline. Rather, he argues "globalization is not destroying the state. It is not doing so because its extent is overstated and the capacity of the state to respond to changing circumstances has been a requirement from its emergence in the seventeenth century" (Bisley, p. 80).

Schotle (2000) supports this view in recognizing that there have been changes in the state such as the end of sovereignty, reorientation to serve supraterritorial as well as territorial interests, downward pressures on public sector welfare guarantees, redefinition of the use of warfare and increased reliance on multilateral regulatory arrangements. $\mathrm{He}$ however argues that while the character of the state has changed the state itself has not been undermined.

Opello and Rosow (2004) writing on nation-states and the global order from a historical perspective argue that post-colonial states have conditional sovereignty. They note that the very "act of colonialism established (territorial) boundaries and created state institutions (colonial structure of civil services, military, church, corporations, and landowner organizations) that constrained and conditioned the sovereignty of postcolonial states at the outset of independence" (Opello \& Rosow, p. 221). These boundaries were set by Europe and accepted as such. Post-colonial states while independent in name however continue to be subject to interventions including military that ensure that "they developed and maintained a particular form of sovereignty that followed the prevailing norms of the European created system" (Opello \& Rosow, p. 
230). Arguably therefore, the role of the state in post-colonial countries within the context of modern day globalization has not changed.

The impact of politics in globalization in higher education is largely played out through governance, policy and the implementation of policy (Levin, 2001; McBurnie, 2001). Policy in $\mathrm{t}(\mathrm{e}$ context of education can perhaps best be described as the attempt by government to direct the activities of educational institutions so that these are compatible with that of government's objectives and as such serves as a regulator. The behavior of the state with respect to higher education can be examined from several perspectives the interventionary state where government is actively involved in institutional activities and actions, the facilitatory state and the evaluative state where the state develops specific targets for the education sector. In some instances the state can be viewed as shielding these institutions from globalization while on the other hand encouraging globalization as such the role of the government tends to be dualistic in nature.

Cultural dimension. Cultural globalization is described as the most direct way in which we experience globalization. Hopper (2007) defines it in very general terms as a catch all term or concept to describe international, transnational, regional, local and global developments that has a cultural dimension. There are a number of debates regarding cultural globalization ranging from the existence of a global culture to the development of hybrid cultures. Pieterse (as cited in Green, 1997), for example, argues that the impact of globalization on culture is one of uniformity and standardization. This is in contrast to another writer, Robertson (as cited in Green, 1997) who views the globalization impact as one of "glocalization" where there is an integration of the global and the local. 
Culture is a concept whose precise definition is highly elusive as it is contested (Kuh \& Whitt, 2000; Tomlinson, 1991). Within the context of higher education defining ant measuring the impact of globalization on culture in higher education is made even more complicated due to the existence of numerous subcultures (Flint, 2000). Kuh and Whitt while recognizing the inherent difficulty in defining culture, however, define culture in higher education as follows:

the collective, mutually shaping patterns of norms, values, practices, beliefs, and assumptions that guide the behavior of individuals and groups in an institute of higher education and provide a frame of reference within which to interpret the meaning of events and actions on and off campus. (p. 162)

Studies of culture in higher education tend to focus on change, effective schools and alternative schools (Flint, 2000). Little attention has been focused on the impact of cultural globalization on higher education and how to measure its impact. Researchers who have sought to assess the impact of cultural globalization on higher education include Levin (2001) and Myers (2007). Levin (2001) recognizing that economics is not the only driving force of globalization and that economics is closely intertwined with culture identified three cultural aspects of globalization in the context of higher education. These were the dominant ideology associated with globalization, the interaction with people from other cultures and the world as a single space. Cultural globalization needs to be referenced to the factors that have influenced the development of the society's culture and its impact on education.

Technological dimension. Technological globalization can be described as the "enabling infrastructure that reframes time and space and facilitates the economic, political and 
cultural" dimensions of globalization (McBurnie, 2001, p.15). It comprises the storage, processing and near-instantaneous transmission of information via the integration of information and communications technology. The enabling infrastructure of globalization include computer mediation technologies such as the internet, intranet, electronic mail, the World Wide Web, and other information technologies such as voice mail, facsimile and video transmission.

According to McBurnie (2001), the visible evidence of technological globalization in higher education includes:

1. the ability to have courses and other materials on-line;

2. transnational education delivery;

3. the development of virtual universities; and

4. alternative pedagogical style.

While McBurnie's focus is on the area of instruction and learning, other researchers (Levin, 2001; Myers, 2007) note that technology also has an impact on the management of academic institutions as well. From an administrative standpoint, technological globalization automated a number of processes such as enrollment and student records and changed the methods of communication among faculty, staff and administrators.

Issues raised in the context of technological globalization in higher education include the problems of regulation and quality assurance with the need for academic and professional qualifications to be portable across national borders and the need to ensure quality. Technological globalization is closely linked to economic globalization since it allows for among other things the reduction in the cost of education and promotes the 
commodification of education. Cultural globalization is also influenced by technology since it allows cultural images and facts to rapidly cross national and cultural boundaries.

Technological globalization can be viewed as both a threat and an opportunity to higher education. Altbach (2006), for example, argues that technological trends such as the Internet "have the potential for creating severe problems for academic institutions and systems in smaller or poorer nations" (p. 24). While Friedman on the other hand, views technology as giving "power for individuals to collaborate and compete globally" (Myers, p. 38).

Postcolonial perspective on globalization. Within the context of developing countries, postcolonial theory emphasizes the impact of developed countries on their higher education systems and on the need for a multidimensional approach to understanding the impact of globalization. Postcolonial theory can be traced back to literary studies in particular the work of Said (Kapoor, 2002; Rizvi, Lingard, \& Lavia, 2006). The theory however has since emerged as alternative to dependency theory. According to Spring (2008), educational researchers who adopt a postcolonial framework view globalization as "an effort to impose particular economic and political agendas on the global society that benefit wealthy and rich nations at the expense of the world's poor" (p. 334). According to this perspective, the worldwide spread of Western type schooling system is a direct result of European imperialism. While colonialism has long since disappeared modern manifestations include Non-governmental Organizations (NGOs), multinational corporations and trade agreements such as World Trade Organization's General Agreement on Trade in Services (WTO/GATS). The main aspects of this new form of colonialism include promotion of market economies, human capital education and 
neoliberal school reforms. Education then becomes viewed as a purely economic investment with the goal being to produce better workers to serve the multinational corporations.

Postcolonial analysis also views the existence of the prevailing global knowledge as being legitimized by the political and economic power of the new imperialists. This analysis supports the existence of multiple sources of knowledge and the fact that these sources of knowledge that do not emanate from the colonial power are not considered on the same level. Further, the global school model is viewed as human exploitation and needs to be replaced by a model that would empower the masses (Spring, 2008).

Educational researchers that have adopted the postcolonial perspective in respect to the globalization of education include Tikly (1999, 2001), Crossley and Tikly (2004), Hickling-Hudson (2004, 2006), and Rizvi (2005, 2006, 2007). Rizvi (2007) for example argues in support of this approach because it shows "how contemporary social, political, economic and cultural practices continue to be located within the processes of cultural domination through the imposition of imperial structures of power" (p. 257). Focus is not only the economic globalization, but also on cultural globalization essential to production and maintenance of colonial relations. Three major points are highlighted by Rizvi (2007). These include the fact that (a) the cultural practices are as critical as the economic in analyzing globalization, (b) that the forces affecting education need to be viewed from a historical perspective and (c) that the relationship between the global and the local is complex and multidimensional.

Tikly's (2001) rationale for the adoption of a postcolonial perspective for analyzing the impact of globalization on education first recognizes that globalization 
theories have been applied in a wide range of scenarios in education literature. He also notes that much of the literature on globalization and education have focused on the developed and the newly industrialized countries. Given this scenario, Tikly not only questions the relevance of these theoretical relationships in the postcolonial context but emphasizes the need to examine more closely the globalization process itself. He poses a very pertinent question, which is how useful are those globalization theories to postcolonial countries. Tikly also recognizes that though some commonality exists among postcolonial countries important differences are evident in terms of their response to globalization.

The postcolonial perspective attempts to retell the globalization process with the postcolonial at the center rather than at the periphery. It examines the continuing impact on education systems of European colonization in the post-colonial context and focuses on issues of race, culture, language as well as other forms of social stratification including class and gender. The perspective also analyzes the resistance to Western global hegemony within education.

Tikly's (2001) framework for conceptualizing the effects of globalization on education policy in postcolonial societies adopts the transformalist perspective of globalization as outlined by Held et al (1999). In presenting this perspective within the context of education, Tikly highlights the main arguments of the transformalist as one where "globalisation works both on and through education policy, i.e. that not only is education affected by globalization but it has also become a principle mechanism by which global forces affect the daily lives of national populations" (p.155). He argues that the advantages of this approach are that it allows for a complex and contingent 
examination of the relationship between education and globalization, focuses on the role of state in mediating the influence of global forces and allows for the incorporation of issues relating to culture, language and identity, issues that are critical to postcolonial perspective.

Two limitations of this approach were however identified. These relate to the fact that the examination of issues of race, culture, class and gender are not meaningfully addressed and also that the impact and relevance of prior forms of European colonization have not been considered. Prior forms of European colonization are a critical element of the postcolonial perspective for three major reasons. Firstly, colonialism resulted in the spread of a common structure of schooling and to the spread of a form of curriculum based on an episteme (ground base of knowledge). The impact has been that it is the basis on which postcolonial reform efforts have had to build. Colonial forms of schooling and the pedagogies and forms of knowledge have proved to be remarkably resistant to change. Secondly, it has contributed to marginalization because schooling was not universal and was highly selective and elitist although it permitted the globalization of English thereby creating a market for Anglo-American cultural forms. Finally, it provided a focal point for the development of local resistance to globalization. Tikly's (2001) framework recognizes that while the literature regarding globalization tends to emphasize the economic aspect of its impact, the post-colonial framework seeks to achieve a greater balance by focusing on the other dimensions of globalization in addition to the economic.

Criticisms of the use of postcolonial perspective range from the conservatives to the Marxist end of the spectrum. Conservatives argue that it undermines Western culture 
and represents a "rampant relativism that has abandoned the Western project of reason, truth and progress. While Marxists on the other hand, see the theory as supportive of global capitalism since it lacks the mechanism to critique global capitalism and its analysis is grounded in neocolonial route.

\section{Measuring Globalization}

Empirical studies of globalization in higher education have tended to be qualitative rather than quantitative in nature (Held et al., 1999; Yoder, 2006). There are only a limited number of researchers who have attempted to quantitatively measure the impact of globalization and education. An example of quantitative research on globalization and education is the work of teVelde's (2005). TeVelde's (2005) research (which derives from the field of economics) measured globalization's impact on education in terms of three globalization processes - trade and foreign direct investment in the education sector, and migration.

Given the limited adoption of quantitative measures of globalization in the education field, the literature on quantitative measures of globalization at the macro (country) level will be examined to determine their applicability to the research study. These country level measures can be divided into two broad categories - statistical indicators (Held et al., 1999, OECD, 2005,) and composite indices (AT Kearney Foreign Policy Globalization Index, Konjunkturforschungsstelle Swiss Institute for Business Cycle Research (KOF index), CSGR Globalization Index, MGI, G-Index and the TransEurope Global Index). The use of statistical indicators such as that of Held et al. (1999) involved the identification of a range of indicators of globalization in several main areas. In the case of Held et al. (1999) these included a number of indicators in the 
following categories - economic, politico-legal, sociocultural, environmental and the military. This approach has limited applicability to the present study because it lacks statistical rigor.

The development of composite indices has emerged as the logical next step to indicators. They involve the identification of indicators representing the various dimensions of globalization and the consolidation of these indicators into a global index. Two of the early works on which most composite indices have been developed are the GIndex and Kearney. The G index was developed in 2001 and focused on the economic globalization in 185 countries. The applicability of this index is limited because it adopts a very narrow definition of globalization and only partial country data are available. The Kearney/Foreign Policy globalization index perhaps the most referenced index also developed in 2001 is based on 12 variables and four categories - economic integration, personal contact, technological connectivity and political engagement. The index has however been criticized because it does not include important dimensions of globalization and the lack of statistical rigor in determining weights (Dreher, 2006; Dreher, Gaston \& Martens, 2008).

Building on the Kearny Index, the Centre for the Study of Globalisation and Regionalisation Globalization index (CSGR) was developed in 2005. The index is based on three dimensions of globalization - economic, social and political and 16 variables. The goal of the index was to provide comparison over time and to have greater applicability to statistical analysis in light of the innovations adopted in analyzing the data sets. This index while further broadening the definition of globalization has limited coverage for developing countries. Another index that builds on Kearney's index is the 
Konjunkturforschungsstelle Swiss Institute for Business Cycle Research (KOF index) which like the CSGR index focuses on three dimensions of globalization - economic, social and political. Similarly, like the CSGR, using objective statistical methods, this index uses 23 variables combined into three sub-indexes and these sub-indexes are aggregated into a single index. The KOF index is the only globalization index that is regularly updated and includes many countries from the developing world. The MGI (Maastricht Globalization Index) is also another example of a composite index which is similar to the KOF index with some important differences. Developed by Martens and Zywietz (2006), this index attempts to improve on earlier indices (Kearney and G-Index). An important measure included in this index is an environmental indicator. This index is however not regularly updated.

The GlobalIndex (Raab et al., 2008) "builds on previous work of Dreher (2006), Lockwood and Redoano (2005), the OECD (2005) and Kearney/Foreign Policy Magazine (2001) but extends this work by additional dimensions and indicators that represent central facets of a sociological concept of globalization" (p. 597). The dimensions included in this multidimensional globalization measure are the economic, (socio) technological, political and cultural. The index expanded on prior quantitative measures of globalization by focusing on expanding the dimensions and their respective indicators. The economic dimension for example extended the analysis beyond that of traditional trade flows to consider trade barriers and agreements. The cultural dimension was also developed by expanding it beyond the consumption styles of everyday life to include "global" norms and values such as human rights and gender equality while the technological dimension focused on the inclusion of (socio) technological 
interconnectedness that includes global exchanges of individuals in addition to global exchanges of information. On the basis of these four dimensions and the related indicators, the authors constructed an overall globalization index for 97 countries over the period 1970 to 2002 .

While this globalization measure is an improvement over previous measure particularly in broadening the definition of globalization, its coverage is limited. The data also have not been updated since 2002 .

The goals of the composite index are generally the same, reverse-engineer globalization and break it down into parts and then combine the data from the different dimensions into one index. Questions have however been raised about whether globalization can be quantified and whether one index adequately describes globalization. Further, many countries are excluded from the majority of these indices due to lack of data which is in part related to their size and the degree to which they are integrated with the regional and global community.

Following the definition of globalization presented in Chapter 1, the measure of globalization adopted will be a composite index (KOF) that measures the economic, political and social dimensions of globalization. With this index technological globalization is incorporated with social globalization.

\section{Globalization and Higher Education: Theoretical and Empirical Literature}

The public provision of higher education and its relation to globalization has largely been analyzed in the literature within the context of social spending (the expansion of the welfare state). The welfare state is defined as "a repertoire of state-led policies aimed at securing a minimum of welfare to its citizens... and providing an 
adequate accumulation of human capital through public investments in health and education" (Segura-Ubiergo, 2007, p. 1). Of the four major theoretical perspectives regarding the expansion of the welfare state that have been identified in the literature, the "logic of industrialism" theory, economic openness theory, class analytical tradition and power resource theory, only the economic openness theory focuses on globalization.

\section{Theoretical Perspectives}

The economic openness theory emphasizes the relationship between economic openness or globalization and the welfare state. Two major perspectives have emerged from this theory, the efficiency hypothesis and the compensation hypothesis.

Efficiency hypothesis. According to the efficiency hypothesis, globalization has a negative impact on levels of social spending. Social spending requires resources that may be gained through taxes on business such as payroll taxes or by deficit spending. Taxes on businesses increase the cost of production, reduce profits and reduce the competitiveness of export and domestic products subject to import competition. Increases in government spending is said to result in increased interest rate which crowd out private investment, increase the real effective exchange rate and inflation creating a macroeconomic environment that is unattractive to global investors.

There are a number of economic incentives for government to reduce social spending. In order to maintain their competitiveness in the face of increasing exposure to international competition, business groups pressure governments to reduce taxes as well as social spending. In developing countries, the pressure is likely to be more severe because trade tends to be highly volatile and the availability of capital is limited. Labor's capacity to resist the reduction in social spending is expected to decline. This is 
particularly so in developing countries where capital is highly mobile and collective action on education is problematic.

Two effects on government resources can be identified. The first sees a shift in spending towards privately productive public inputs such as education, training and research and development. Secondly, due to the international mobility of capital and income, tax revenues decline resulting in a reduction in total government expenditure. Saahdong (2010) however notes that it may increase the tax base. While education is not affected in the same way as other social spending components as it is not typically financed by business taxes, it is likely to be vulnerable to fiscal constraints anticipated. Compensation hypothesis. While the efficiency hypothesis argues that there is a negative relation between globalization and social spending, the opposite is true for the compensation hypothesis. Globalization results in greater social inequity and more economic insecurity and there is a strong political incentive for government to increase social spending as governments face pressure to compensate the losers in the globalization through spending on social programs. This may take the form of unemployment protection, training, and welfare transfers to social sectors or regions affected. In the context of education, governments face pressure from business and workers for an educated workforce to make them more attractive for foreign firms to invest.

Increased social spending is also rationalized from an economic perspective as it can be used to enhance the skill and productivity of the labor force which would improve the competitiveness of the economy as a whole. Formal education has proved important in improving the human capital long argued in economic literature as important for 
economic growth. This is also of interest to foreign investors who expect higher returns from workers with better education and skills. The more open the economy are subject to larger and more frequent external shocks so that citizens demand government provide more social insurance.

\section{Empirical Literature}

The conclusion of the literature on the dominance of the efficiency versus compensatory hypothesis has best been described as inconclusive with differing studies finding support for both. The study of social spending in 14 Latin American countries conducted by Kaufman and Segura-Ubiergo (2001) represents groundbreaking effort in this area. The research covers the period 1973 to 1997 using dynamic time-series crosssectional (TSCS) models. The study did not use an education measure per se but rather a human capital measure that combined education and health spending measured in three different ways: as a share of Gross Domestic Product (GDP), public expenditure and per capita. Globalization was measured as trade openness and capital liberalization. The results show no significant impact on human capital spending for the trade openness measure of globalization while the capital liberalization measure was positive however the findings were not robust. A similar study of 17 Latin American countries by Brown and Hunter (2004) over the period 1980 to 1997 corroborated the result showing that globalization as measured by trade openness has a null,-effect on education spending. Brown and Hunter utilized the TSCS method but disaggregated human capital into education measured as total education spending per capita.

Other studies on Latin America however have been mixed. Takahashi (2004) adopted the same methodology and definitions of Kaufman and Segura-Ubiergo (2001) 
to examine the effect of globalization on social spending in 13 Latin American countries from 1980 to 1997. The results showed that trade openness had a negative effect on human capital spending, measured as a share of GDP and positive for capital account liberalization. The findings however are not robust to model specifications. Avelino, Brown and Hunter (2004), in a similar study of 19 Latin American countries for the period 1980 to 1999 , found that while trade openness is positively correlated with education, financial openness is not significant. This finding is similar to Huber, Mustillo and Stephens (2004) whose model includes four measures of globalization - trade openness, foreign direct investment, central government deficit and International Monetary Fund (IMF) repurchase obligations. Using health and education spending as the dependent variable the results show that trade openness has a significant positive effect. Government deficit was also significant. Foreign Direct Investment (FDI) and IMF indicators were however null.

Two studies that have examined this issue for the Asian region have also produced conflicting results. Shapoatov's (2009) study used 14 East Asian countries over the period 1990-2003. Using trade openness as the globalization measure, the results showed that globalization has a significant positive impact on education measured as expenditure as a percentage of GDP. In a much more comprehensive study that included eight East Asia countries over the period 1971 to 2003, Chen (2007) concluded that there was no robust relationship between globalization and education variables.

Other quantitative studies using developed countries (mainly countries of the Organisation for Economic Co-operation and Development (OECD)) and those that include both developing and developed countries have also produced conflicting results. 
Saahdong's (2010) study of four Nordic countries for example over the 1990-2007 period found that trade as a measure of globalization has a negative impact on education while KOF and FDI had no significant impact. Rudra and Haggard's (2005) study of 57 Less Developed countries using TSCS data over the period 1975 to 1997 examines the determinants of government social spending including spending on education. This study uses two measures of globalization, trade and capital flows and two measures of education, spending and enrollment. The results showed that for the pooled sample the only significant result was education spending and trade and this showed a negative relationship. This finding is contrast to that of Nooruddin and Simmons (2009) whose study of developing countries over the period 1977 to 1997 found that education measured as the share of government total spending on education and globalization measured as imports as a share of GDP is positive and significant using the level but nonsignificant to the change variable.

One of the major criticisms of the empirical studies of the impact of globalization on social spending analyzed above is that of data limitations (Chen, 2007; Rudra, 2004; Rudra \& Haggard, 2005). More specifically, the use of aggregate data on education spending does not indicate how resources are allocated among the primary, secondary and tertiary levels of education. This has implications for the interpretation of results since primary education for example is generally associated with more redistributive spending. A related criticism regarding data is that the use spending measures which it is argued does not effectively capture government commitment to education. In response to this criticism alternative outcome variables have been proposed. Rudra and Haggard (2005) included enrollment ratios as an educational outcome. This approach has been 
adopted by Chen (2007) who expanded the outcome variable to include attainment and gender equity. This research study will continue in this trend by the use of disaggregated data and educational outcome measures.

\section{Other Theories of Education Expansion}

While there are a number of theories that seek to explain educational expansion, in the sphere of higher education the emphasis has been on the functionalist, human capital, world system/institutional and conflict theories.

Functionalist theory. The main proposal of this theory is that national economic development is the driver for higher education expansion (Schofer \& Meyer, 2005). The demand for greater investment in higher education is both collective and individual. Increased national development provides the means through which this increased demand can be met. The theory has also been expanded to the global level where expansion of higher education in the core countries becomes a critical component of control of the periphery countries. There has been little support however both empirically and theoretically for this theory. The institutional and conflict theories have emerged as alternatives to functionalism.

Human capital. Human capital theory, which emphasizes the changing structure of the job market and the changing patterns of the needs for specific jobs, was developed in the context of modernization theories. This theory perceives a linear, market-related relationship between the need for trained human resources and the expansion of education. Education is considered as an investment that will pay off later in the form of better paying and/or more prestigious jobs. As returns on educational investment increase, so will the number of people seeking more education (See Becker, 1964; Blaug, 
1970; Freeman, 1976; Mincer, 1958; Schultz, 1961 as cited in Tian, 1996). This theory has been challenged by the conflict theory and world system theory with empirical data indicating that supply of higher educated persons has exceeded the demand.

World system theory/Institutional theory. Research guided by world system theory, however, rejects human capital theory (See Meyer et al. 1977; Ramirez \& Rubinson 1979; Ramirez \& Boli-Bennett 1982 as cited in Tian, 1996). World system theory holds that in modern societies, the state is the major institution responsible for nation building and social development. The actual implementation of those goals, however, is dependent on individual efforts. It is suggested that citizenship is the key to link the individual with the state. Citizenship entails that individuals are contributors to national development as well as legitimate consumers enjoying all benefits provided by the state. School education is essential to teaching skills necessary for the citizens to engage in nation building and individual development. The state as an institution is the major actor in the development of the educational system. Educational expansion is therefore a product of the joint effort from the state and individuals to produce the citizen. Although world system theory hints at a possible role of individuals in educational expansion, its emphasis is on the state and the role of the state in educational expansion.

The institutional theory (Schofer \& Meyer, 2005) concentrates on the changes in societal models that have engendered the expansion of higher education. At the global level these changes include democratization and the expansion of human rights, scientization, national development and planning and global structuration. The expansion of higher education at the national level proceeds more rapidly for countries strongly linked to these world models. 
Conflict theory. The main argument of this theory is that educational expansion is a result of competition among ethnic groups for status and power (See Bourdieu \& Passeron, 1977; Boudon, 1974; Collins, 1971, 1979 as cited in Schofer, 2005; and Tian, 1996). With education increasingly becoming an important element of social status, groups will seek more and more education resulting in inflation of credentials. Thus expansion in higher education is not a reflection of functional requirements but the competition among groups for status and prestige. Competitive pressures are also affected by the level of organizational decentralization. Schofer and Meyer (2005) hypothesize that "under conditions of high institutionalization of higher education, expansion will be rapid in decentralized systems, but may be controlled in centralized ones (p. 901).

\section{Summary}

In reviewing the literature regarding globalization in higher education, it was recognized that the findings regarding the impact of globalization on education were inconclusive. Furthermore, to my knowledge while empirical studies have been conducted separately for developed and developing countries, no statistical analysis has been conducted on the impact of globalization on the public provision of higher education from a "world" perspective. The main purpose of this study is to address this gap in the literature. The research methodology that will be used in the study, the data collection and data analysis process are presented in Chapter 3. 


\section{CHAPTER 3}

\section{RESEARCH METHODOLOGY}

The research methods that were applied in completing this study of the relationship between globalization and higher education are discussed in this chapter. The following objectives are undertaken: identification of the research questions and hypotheses that will form the basis of the study; and discussion of the research design that will be adopted and the related procedures for data analysis. The research design presented below is based on the analytical and theoretical framework outlined in Chapter 2.

\section{Research Questions and Hypotheses}

The central question guiding this study was: What is the relationship between the process of globalization, its related forces (economic, political, cultural and technological) and the public provision of higher education? To answer this central question, the study will focus on the following sub-research questions:

1. What is the relationship between globalization and public spending on higher education?

2. What is the relationship between globalization and other selected higher education outcomes (participation, attainment and gender equity)?

3. Which dimensions of globalization (economic, political, cultural, technological) account for unique variance when controlling for the other dimensions in the public provision of higher education?

For question 1, the relationship between globalization and government spending on higher education, I hypothesize a positive relationship. The rationale for this predicted 
relationship derives from the fact that higher education of the population has long been recognized as critical for the continued growth and development of economies. It is therefore reasonable to expect that governments will continue to place emphasis on higher education in the face of increasing integration into the global economy. Hypothesis 1: The greater the level of globalization as measured by the KOF globalization index, the more a government spends on higher education.

Regarding the relationship between globalization on educational outcomes, I hypothesize a positive relationship between globalization and educational attainment, participation, gender equity in higher education. This is because students and parents have incentives to participate and perform better in education so they could be rewarded by the global economy, which requires increasingly higher skills. Also, public policy measures such as improved access to funding for education as well as measures that provide incentives for private provision of higher education can improve access and quality.

Hypothesis 2: The greater the level of globalization as measured by the KOF globalization index, the better the level of higher education outcomes as measured by educational attainment, participation and gender equity.

I hypothesize a general positive relation between economic globalization and the provision of public higher education. Globalization has a number of dimensions (economic, technological, cultural, political). However, while they are interdependent, it is generally recognized that economic globalization is one of the leading factors influencing globalization in education. 
Hypothesis 3: The public provision of higher education will have a greater association with economic globalization as measured by the KOF economic globalization index, compared to the KOF political, cultural and technological globalization indices.

\section{Research Design}

This research study will utilize a non-experimental quantitative research design to analyze the relationship between globalization and the public provision of higher education. A non-experimental quantitative design is defined as "research in which the independent variable is not manipulated and there is no random assignment to groups" (Johnson \& Christensen, 2004, p.328). There are two approaches to this design, the correlational or causal and the causal-comparative or criterion group (Cohen, Manion, \& Morrison, 2003; Johnson \& Christensen, 2004). The correlational method was chosen for this study because, in contrast to the causal-comparative method, it allows relationships among variables to be examined. As such, this method corresponds to the study goals to discover the degree of relationships between globalization and spending on higher education and other selected higher education outcomes.

The use of the non-experimental quantitative method has a number of advantages and disadvantages. Advantages include (a) that is it useful when the experimental approach is not possible for ethical or practical reasons, (b) that it yields more information regarding the nature of the observations and thus serves as a valuable exploratory tool, and (c) that it has high external validity (Cohen et al., 2003).

Disadvantages of the method largely focus on the lack of internal validity because of (a) lack of control of the independent variables and the inability to randomize subjects and (b) lack of certainty regarding causation. Spector (1981) however notes that this emphasis 
on the difficulty of proving causation may be overstated somewhat as "many experimental designs are so fraught with confounding variables that casual inferences cannot be made with any reasonable confidence, and there are non-experimental, observational designs that can establish causal chains of events" (p. 24).

Quantitative studies of the impact of globalization on public spending are often characterized by macro analysis of a large number of cases using time-series crosssection (TSCS) or panel data. This methodology has a number of advantages and disadvantages.

Advantages of using TSCS data (Podesta, 2002; Worrall \& Pratt, 2004) include the fact that it increases the sample size and thus the degrees of freedom and it also allows researchers to control for unobserved time-stable features of each unit of analysis (individual heterogeneity). Researchers have also argued that TSCS data because they are longitudinal are an excellent design for causal analysis. Other advantages that this design offers over other cross-sectional approaches are that it addresses the problems of estimation bias and multicollinearity as well as in improving model identification and discriminating between hypotheses.

However, the use of pooled data poses a number of problems. Researchers (Podesta, 2002; Worrall \& Pratt, 2004) have identified several such problems including that of serial autocorrelation, heterogeneity, heteroskedasticity, unit-specific trends, nonstationarity, spatial correlation, and contemporaneous correlation. There are however a number of methods that have been devised to control for these problems (Beck \& Katz, 1995, 1996). While this approach (TSCS) has a number of advantages, its applicability to 
this study is very limited because of missing data which would limit the cases primarily to that of developed countries and the time period from the 1980s.

A cross-sectional design across countries will therefore be adopted since this study intends to study a greater number of countries over a longer time period (from the 1970s). While this method is less sophisticated than TSCS, by using averages for different time periods, the historical dynamics between globalization and education can be ascertained.

\section{Data}

The principal data sets chosen for this study are based on internationally standardized data collected and processed by agencies such as the United Nations and the World Bank. The variables and their respective sources are described later in this chapter. These data sets will be cross referenced to maximize the size of the data set. The choice of data set was based on the importance of comparisons across countries and over time. The major problem faced with collecting global data will be that developing or underdeveloped regions lack comprehensive reporting on many factors. Based on data availability, a decision will be made to either eliminate countries or variables lacking sufficient data. The period chosen ranges from 1970 to 2009. The choice of this period was based on two major factors. They are the availability of data and the possibility that the time period allows for tracing the relationship between globalization and higher education over time. 


\section{Empirical Model Specification}

To test the implications of the hypotheses regarding the public provision of education, several variants of the general formulation of a multiple linear regression model will be estimated. The model is as follows:

$$
Y_{t}=a+\beta_{1} G_{t 1}+\beta_{2} X_{t 2}+\mu
$$

where Y represents the dependent variable (the public provision of education); $\mathrm{G}$ and $\mathrm{X}$ represent the explanatory variables ( $\mathrm{G}$ is the globalization indicator, $\mathrm{X}$ is a vector of control variables); a is the intercept; and $\mu$ is the error term (Meyers, Gamst \& Guarino, 2006). The strength of the relationship between the explanatory variables and the dependent variable is measured by the beta coefficients ( ). The subscript $t$ refers to the number of observations which varies from 1 to $\mathrm{T}$. The regression equation will be estimated using the ordinary least square (OLS) standard regression method. With this method, all the explanatory variables are entered into the equation simultaneously.

\section{Variables}

The model uses annual data from 1970 to 2009 to examine the relationship between globalization and the public provision of higher education. The description and source for these variables are as follows (See Appendix A).

\section{Dependent Variables: Higher Education Indicators}

Spending on education. Public spending on higher education is a direct measure of the priority placed on higher education by government. Governmental funding of education has been measured in three major ways in the literature (Ansell, 2008; Baskaran \& Hessami, 2010; Chen, 2007; Kaufman \& Segura-Ubiergo, 2001). They include (a) the use of spending on education as a percent of GDP which measures the 
priority of education in the national budget, (b) spending on education per capita which measures educational resources available to the population and (c) education spending as a percent of total government spending which measures the allocative priority given to education within the national economy as a whole.

For this study the measure of higher education funding adopted will be higher education spending per student as a percentage of GDP per capita, which measures the resources available to students in higher education (SPENDGDPCAP). These data are available on the UNESCO database.

Other measures of higher education spending will be used in sensitivity analysis. These are:

1. spending on higher education as a percentage of total government education spending to measure the priority attached to higher education by the government (SPENDTOT). This data are available from the UNESCO database (Educational expenditure on tertiary education as percentage of total education expenditure); and

2. higher education spending as percentage of GDP, which measure the allocative priority of higher education within the national economy as a whole (SPENDGDP). This data are available from the UNESCO database (Total expenditure on educational institutions and administration as a \% of GDP. Public sources. Tertiary). This variable was however excluded due to limited data availability.

Educational outcomes. The measures of educational outcome adopted for this study are attainment, participation and gender equity. These indicators are as follows: 
Participation. (PARTIC) Participation is an indicator of how well citizens are able to participate in the education system of their countries determined in part by government's provision of education and household's participation behavior. It is measured as gross enrollment ratio defined as the number of students of a certain age group enrolled in higher education as a percentage of the country's population of the same age. It has, however, been noted that the net enrollment ratio presents a more accurate picture of participation since it excludes children enrolled at a certain level but above official school age. However, data on net enrollment is limited. Data for gross enrollment ratio was obtained from UNESCO and is available annually from 1970 to 2010 .

Educational attainment. (ATTAIN) Educational attainment reflects the efficiency and quality of the education system and gives a different view of accessibility compared to the participation rate since it focuses on completion. It is measured as the percentage of the population of a particular age group that has attained higher education. For this study, attainment is measured using two variables, the average years of tertiary schooling of the population over 15 years (ATTAINY) and the percentage of the population 15 years and over attaining education at the tertiary level (ATTAINP). Data are available at 5 year intervals beginning in 1950 and was sourced from Barro and Lee (2010). Barro and Lee use estimation procedures based on benchmark data available from the UNESCO, Eurostat and other sources to determine educational attainment data.

Gender equity. (GENEQU) Gender equity is an indicator of equitability of access to education based on sex. Higher education gender equity (Gender Parity Index) is measured in two ways in the literature, in terms of enrollment and progression 
(completion). A ratio of one indicates gender equity (less than one, a disparity in favor of men and a ratio of greater than one, a disparity in favor of women).

For this study, gender equity based on enrollment is measured as the ratio of women to men enrolled in higher education using data on gross enrollment ratio (GER) in higher education (Female GER/Male GER). This index (Gender Parity Index) has been published by UNESCO starting in 1970 .

The second measure of gender equity, progression, arguably gives greater insight into the gender equity of the education system as it focuses on completion of higher education rather than simple enrollment. It is measured as the ratio of women to men completing higher education. This variable will be constructed using tertiary completion data (Female completion rate/Male completion rate) available at 5 year intervals beginning in 1950 from Barro and Lee (2010) - percentage of the population 15 years and older for females and total population completing tertiary education.

\section{Explanatory Variables}

The explanatory variables are grouped into two categories. They are the globalization indicators and the control variables. The control variables include economic, demographic and political indicators.

\section{Globalization Indicators}

The common practice in the literature on globalization is to measure globalization as financial and trade openness. However, recent empirical literature has focused on a broader measure of globalization given the multidimensional nature of the construct (Baskaran \& Hessami, 2010; Dreher, Sturm \& Ursprung, 2008; Potrafke, 2009). As discussed in Chapter 2, there have been a number of attempts at a more comprehensive 
measure of globalization. KOF index of globalization (KOF) will be used for this study because of the advantages discussed earlier (Dreher, Gaston \& Martens, 2008) and because the index is available from 1970 to 2009 . The KOF index is based on three subindexes which capture globalization along three main dimensions - economic, political and social. Each of these three dimensions has further sub-indexes. (See Appendix B for the variables that comprise the KOF index and their corresponding weights.)

Tests for robustness of the results will be conducted using trade (TRADE) and foreign direct investment (FDI) measures of globalization that have traditionally been adopted in the literature (Dreher et al, 2008). Openness to trade will be measured as the total of imports and exports as a percentage of GDP and will be calculated based on purchasing power parity. Financial openness will be measured as inflows of FDI as a share of GDP. Gross FDI overall net impact (sum of absolute value of inflow and outflow stocks of FDI as a share of GDP) is not used for this study because of data limitations. Data was sourced from the IMF. the World Bank and the KOF Swiss Economic Institute.

\section{Control Variables}

A general problem in empirical research when there is no accepted theoretical model is the appropriate choice of covariates (Dreher, Sturm, \& Ursprung, 2008). In addition to the key variables of interest, I also include several control variables traditionally used in social spending literature (political, economic, demographic) that are likely to be related to changes in the government's provision of education. The specific controls included for each model will depend on the dependent variable. The final choice of the control variables to include will be based on the theoretical framework adopted for 
this study, data availability and the empirical tests to determine the contribution of the variables to the total variance of the model.

Economic controls. Economic factors are among the most important controls on the public provision of education. Economic controls will be included in the baseline model based on variables traditionally included in the literature.

Real GDP per capita (GDPPC). GDP per capita is total gross domestic product of a country divided by the total population (constant US dollars). This variable captures how a country's income level is related to the structure of education expenditures (Baskaran \& Hessami, (2010).). This data are available from Penn World Tables.

Total education expenditures (TOTEDEXP). This variable is calculated as total education expenditure per student as percent of GDP per capita. The rationale for including this variable is that since the focus of the research is on how higher education has changed with globalization, total education expenditures needs to be controlled (Baskaran \& Hessami, 2010). This variable is published by UNESCO Institute for Statistics.

Urbanization (URBAN) measures the percentage of the population that lives in areas defined as urban. Educational outcomes such as participation and enrollment tend to be higher in urban areas because of greater accessibility (Chen, 2007). This indicator is available from the World Development Indicators.

Economic growth (GROWTH) is the annual percentage growth rate of GDP. Economic growth accounts for the fact that government spending is influenced by business cycles arguably countercyclical in developed countries because of built in stabilizers such as unemployment insurance. In developing countries, business cycles are hypothesized to be 
procyclical because of the absence of such stabilizers. This indicator is available from Penn World Tables.

Ratio of capital stock to GDP (CAPSTOCK). This measures the skill intensity of a country. The skill requirement of a country may affect government's investment in higher education. The higher the skill intensity, the higher the percentage of population participation and attainment of higher education will be. This is measured as gross capital formation divided by GDP and is available from the World Development Indicators.

Demographic controls. The size and structure of the population is an important influence on education provisions since changes in spending for example may simply be a reflection of changes in school age population (increasing and decreasing as school age population increases and decreases respectively) and therefore should be controlled for.

The demographic variable adopted for this study is the population share of the age groups relevant to higher education levels (POPSHARE) to capture demographic pressures on the provision of education (Baskaran \& Hessami, 2010).), and lagged secondary gross enrollment rates (SGERL) and lagged percentage of population with secondary education attained (SAL) to control for the population available at the tertiary level. These variables were obtained from the Penn tables' database and UNESCO. I expect a positive relationship between the size of the population and the public provision of education.

Political controls. Political controls are a critical aspect of the impact of globalization on higher education since education is directly affected by government's spending and other policies which affect access. The political control variable used in this study is democracy. 
Democracy/Popularly based government. (DEMOCRACY) Whether the high or middle income groups control political decision making affects the provision of higher education. Following Ansell (2008), a polity index derived from Gurr's Polity IV data are used to measure democracy. The index ranges from -10 (the most autocratic state) to +10 (the most democratic state) by 1-point increments. The score is comprised of a variety of scores of political competitiveness and restrictions on executive participation and recruitment. Using Gurr's Polity IV data, democracy is measured by subtracting the autocratic (AUTOC) score from democratic (DEMOC) score.

\section{Data Analysis Procedures}

Data analysis for this study was conducted using the SPSS statistical software. Both descriptive data analysis and regression analysis were used and are described in this section. For the description analysis of the data, measures of central tendency (mean), dispersion (range), spread (standard deviation) and dependence (correlation) for the globalization indicators and measures of higher education are presented. This analysis will be done for the period 1970 to 2009 . The relationship between globalization and higher education will be analyzed within the context of the theoretical and analytical framework presented earlier.

For the regression analysis, the relationship between globalization and higher education will first be examined for all countries in the data set using the model specified earlier. T/he data set will then be split according the level of development (developed and developing) and by geographical region and the regression repeated for each group. The hypotheses will also be examined for different time period using five year averages. 
The values obtained from the SPSS output were tested for statistical significance using the traditional alpha level of .05 for Type 1 error rate. Type 1 error occurs when a true null hypothesis is rejected, also known as a false positive. Another possible error that must be controlled for is the Type II error which occurs when a false null hypothesis is not rejected. Increasing statistical power, defined as 1- beta, reduces the possibility of a Type II error occurring.

Statistical power is based on three factors: the alpha level, the sample size and the effect size (Meyers, Gamst \& Guarino, 2006). The alpha level or Type 1 error rate is inversely related to statistical power. Power, however is positively related to sample size and effect size. The effect size is a measure of the strength of a relationship and is categorized as small, medium and large. The larger the effect size the greater the statistical power. The recommended minimal standard for power is .80 (Lipsey, 1990). An a priori power analysis will be conducted to determine the minimum sample size required to get a significant result. All tests conducted throughout the study will be onetailed and will be considered significant at $<.05$.

The data analysis will begin with checking the descriptive statistics (mean, variance, standard deviation, maximum and minimum) of the variables. Statistical analyses using correlation and regression analyses will then be conducted to estimate the relationship between globalization and the public provision of higher education. Pearson correlation tests will be conducted to determine the degree to which the variables are related. The results will be shown in tabular and graphical form. The relationship between education and globalization will then be examined by means of regression 
analysis (Ordinary Least Squares) for all the countries in the data set for different time periods.

Using regression analysis, the relationship between globalization and spending on higher education will be estimated using higher education expenditure per student as a percentage of GDP per capita (SPENDGDPCAP) as the dependent variable. Sensitivity analysis will be conducted using the other two measures of spending on higher education (SPENTOT, SPENDGDP) traditionally used in the literature. The measure of globalization will be the KOF index. Sensitivity analysis will also be conducted using the other three measures of globalization traditionally used in the literature.

Previous studies of government social spending and globalization have focused on a wide range of control variables and, with some exception, notably per capita GDP, there is no general agreement with respect to the variables that should be included in the baseline model. Further, only a limited number of studies focus on education and higher education in particular. Variables traditionally considered fall into three categories economic indicators such as per capita GDP, demographic indicators such as population size and political indicators such as democracy. Based on the theoretical framework presented in Chapter 2 and variables traditionally adopted by empirical studies that focus on higher education (Baskaran \& Hessami, 2010; Chen, 2007), the explanatory variables proposed for inclusion in the baseline model are real GDP per capita, democracy, population size, education expenditure per student as percentage of GDP per capita, government expenditures as share of GDP, business cycle, government revenue and the ratio of capital stock to GDP. The final choice of the control variables to include in the 
model will be based on data availability, their significance and problems of multicollinearity.

The relationship between of globalization and educational outcomes (attainment, gender equity, participation) in higher education will then be examined. Following Chen (2007), the baseline model for the selected outcomes of higher education will include controls for educational spending (EDSPEND), urbanization (URBAN) as well as controls for the population available to be educated at the tertiary level (SGERL and SAL for the attainment and participation models). Other controls include economic (GDP per capita, capital stock as a percentage of GDP), political (democracy), and globalization (KOF). The final model that will be estimated will be determined based on data availability and goodness of fit. Sensitivity analysis will also be conducted using alternative measures of globalization (Trade, FDI, Capital account restrictions), demographic (POPSHARE), political (Ideology, Electoral cycle) and economic.

The effect of the forces of globalization (economic, political, social) on higher education spending and the selected higher education outcomes will be estimated by extending the respective baseline models to include the three forces of globalization. The analysis will be replicated by replacing the aggregate globalization index (KOF) with the sub-indices for the three dimensions of globalization (ECONG, POLG, SOCG). To account for possible correlation among the sub-indices, the analysis will also be replicated by including each sub-index separately. Sensitivity analysis based on changes in the economic, demographic and political controls will also be conducted.

The interpretation of the regression analysis will be based on four criteria. These criteria are the R-square value, the F-value and the statistical significance and sign of the 
beta coefficients (Ramanathan, 1992). These will be used to determine the final model. The R-square (explained variance) will be used to indicate what percentage of the variability of the dependent variable (public provision of higher education) can be accounted for by the independent variables (globalization and the control variables). The ANOVA will be used to determine whether the model is statistically significant that is whether the $\mathrm{F}$ value has an associated probability of .05 or less. The t-statistic and associated sign of each independent variable will also be examined to determine whether the beta coefficient is statistically significant. The sign of the beta coefficients (positive or negative) will also be interpreted in terms of the stated hypotheses.

Once the final models has been estimated (based on statistical significance and theory) the adequacy of the regressions' assumptions of normality and Gauss-Markov assumptions (linearity, independence, heteroscedasticity) will be checked (Ramanathan, 1992). Normality will be checked using the normal quantile plot. If the assumption of normality is violated due to the violation of the linearity assumption or because the distributions of the variables are not normal, a nonlinear transformation of the variables will be conducted. If it is due to one or two very large errors consideration will be given to removing these variables. Independence will be determined using the Durbin-Watson statistic. If there is positive serial correlation, the addition of lags to the dependent and/or independent variable will be considered. If there is negative correlation consideration will be given to whether some variables have been over differenced. Linearity will be checked for by examining nonlinear trends in the residuals. If the linearity condition is violated, a nonlinear transformation will be applied to the dependent/and or independent variables. Heteroscedasticity will be determined by visual inspection of the residual scatter plot. 
This violation may be addressed through logging or may be fixed as a byproduct of fixing linearity and/or independence assumptions.

\section{Tests for Robustness}

In light of the criticism of the influence of model specification on the findings in the literature, the robustness of the model will be tested to examine its validity using the following methods:

1. Varying the specification of the globalization variable. Alternative measures of globalization that will be included are trade, FDI and capital account restrictions. These measures have been defined earlier in the chapter.

2. Varying the controls entered into the model. Alternative demographic, political and economic measures as defined earlier in the chapter will be used.

3. Varying the period, country grouping.

A finding is considered robust if it is insensitive to all these changes in the model.

\section{Organization for remaining chapters}

In the following chapters (4 and 5) I will analyze the data and on the basis of this analysis present my findings and recommendations for future research. 


\section{CHAPTER 4}

\section{DATA ANALYSIS}

Research on the relationship between globalization and higher education is limited in the literature. Moreover, the empirical evidence linking these two variables (globalization and higher education) has been highly inconclusive. The purpose of this study is to address the following research question: What is the relationship between the process of globalization and its related forces (economic, political, cultural and technological) and the public provision of higher education?

This study focuses on two main limitations identified in the literature. They are questions regarding the measurement of globalization including the multidimensional nature of the variable and the use of alternative measures of higher education apart from spending such as attainment, participation and equity.

I approach this chapter by first focusing on the descriptive analysis of the key variables, globalization and higher education, for all the countries selected for this study. See Appendix C for the list of countries included in the study. Correlation analysis was also conducted as a second step in order to obtain the crude associations between the indicators used. For this Pearson's correlation analyses was applied.

Next, a simple linear regression analysis was performed to gain an insight in the possible associations between globalization as measured by the KOF index and higher education indicators, as well as the strength of these associations for each of the globalization dimensions. This was done using two basic models, spending and educational outcomes. The spending model examined the relationship between spending on higher education and globalization over the period 1970 to 2009 using cross sectional 
analysis. The educational outcomes model examined the relationship between attainment, gender equity and participation in higher education and globalization over the same period. Subsequently, multiple linear regression analysis was performed, in order to a assess if and to what extent globalization as measured by the KOF index can explain a proportion of the variance in the dependent variables (spending, attainment, equity, participation) while controlling for selected economic, political and demographic factors.

\section{Descriptive Analysis}

This section presents the descriptive analysis for higher education, globalization and the controlling economic, political and demographic factors. The variables will be described and analyzed by trend over time period (1970 to 2009) for all the countries included in the study.

\section{Higher Education Indicators}

Measures of higher education for this study are in two categories - spending and educational outcomes. Three measures of higher education expenditure have been identified in the literature. They are spending per student as a percentage of GDP per capita, spending as a percentage of total government expenditure and spending as a percentage of GDP. Spending as a percentage of GDP has been excluded from this study because of data limitations mainly because of the change in method of calculation in the 1990s which makes the earlier data incomparable. The educational outcome measures of higher education are attainment, gender equity and participation. These measures are included in recognition of the fact that spending alone may not adequately capture the state of a country's higher education. 
Expenditure. Public spending on higher education is a direct measure of the priority placed on higher education by government. The two measures adopted by this study are spending on education per capita (SPENDGDPPCAP) which measures the educational resources available to the population and education spending as a percent of total government spending (SPENDTOT) which measures the allocative priority given to education within the national economy as a whole. Figures 1 and 2 shows the trend over time of spending on higher education. An interesting and unexpected trend appears to be the decline in spending on higher education per student as a percentage of GDP per capita for the entire period under review. However, for the alternative spending indicator, spending as a percentage of total government expenditure (SPENDTOT), the trend is positive, effectively with the 2009 figure increasing by almost twice over that of 1970. It is important to note however that both indicators appear to be relatively constant in the mid 2000 to 2009 period. 


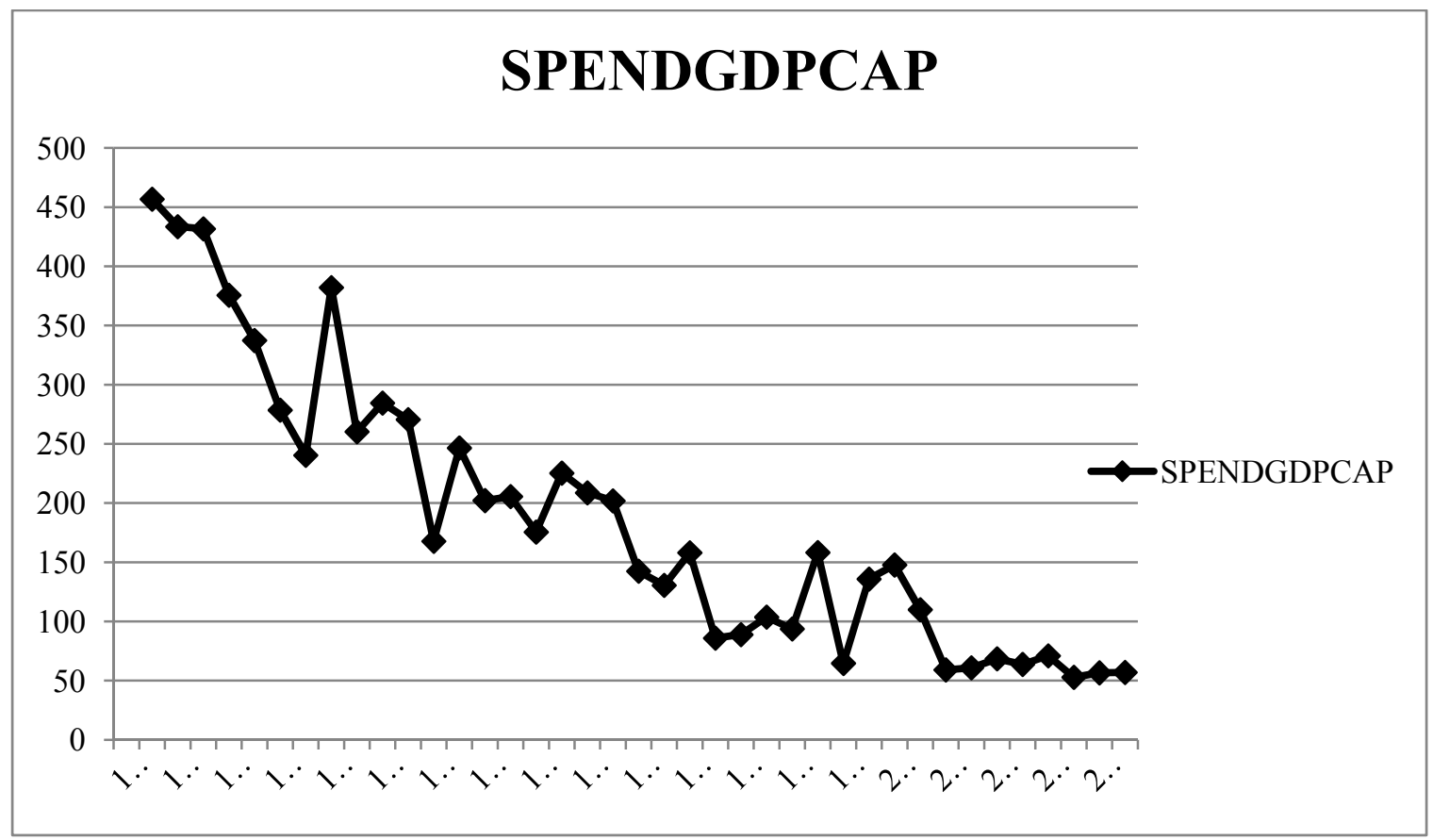

Figure 1. Time trend of higher education variable: SPENDGDPCAP. This figure shows the average development of higher education spending per student as a \% of GDP per capita over the period for selected countries.

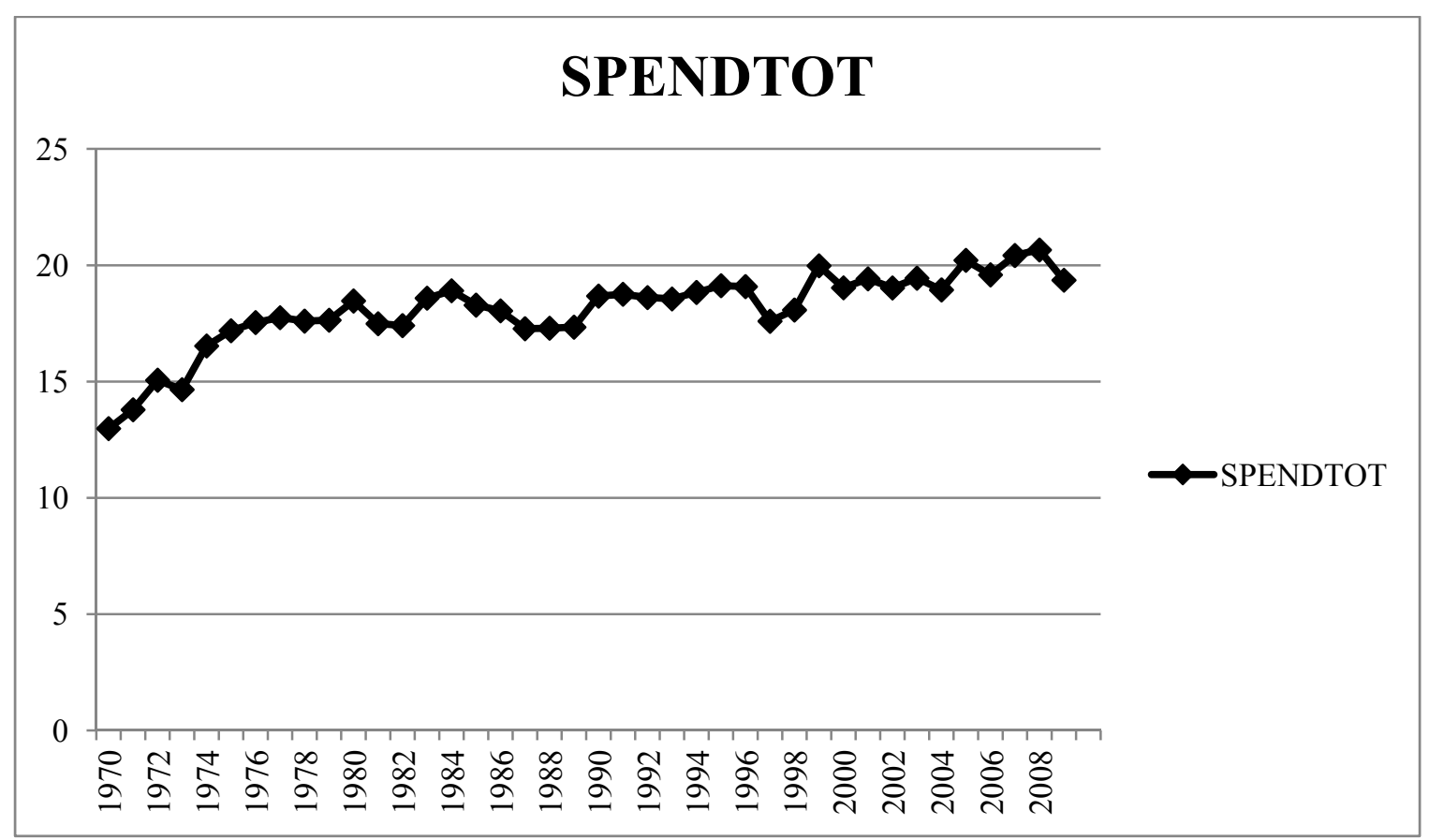

Figure 2. Time trend of higher education variable: SPENDTOT. This figure shows the average development of higher education expenditure as a percentage of total government spending over the period for selected countries. 
Equity. Gender equity in higher education is used as an indicator of equitability of educational access based on sex. Two measures of gender equity have been adopted for this study, gender equity based on enrollment figures (GENEQUGER) and completion rate (GENEQUC). Both measures of equity show steadily increasing equity in higher education with the disparity generally in favor of men for most of the period under review. The trend of increasing equity in the gender in higher education is shown in Figures 3 and 4. It should be noted that in the case of the enrollment measure in the mid 2000 the disparity favored women.

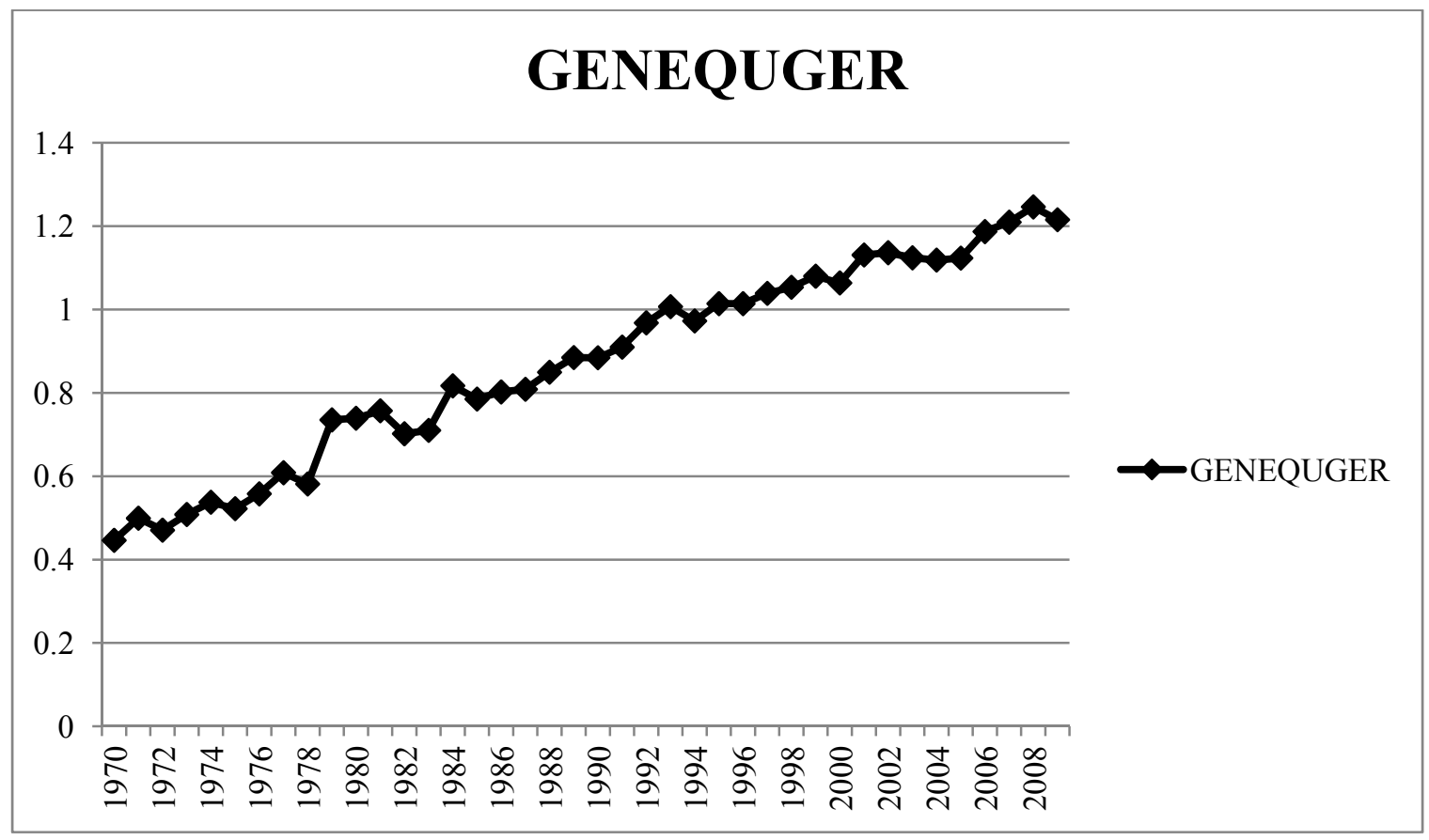

Figure 3. Time trend of gender equity variable: GENEQUGER. This figure shows the average development of the ratio of females to males enrolled in higher education over the period for selected countries. 


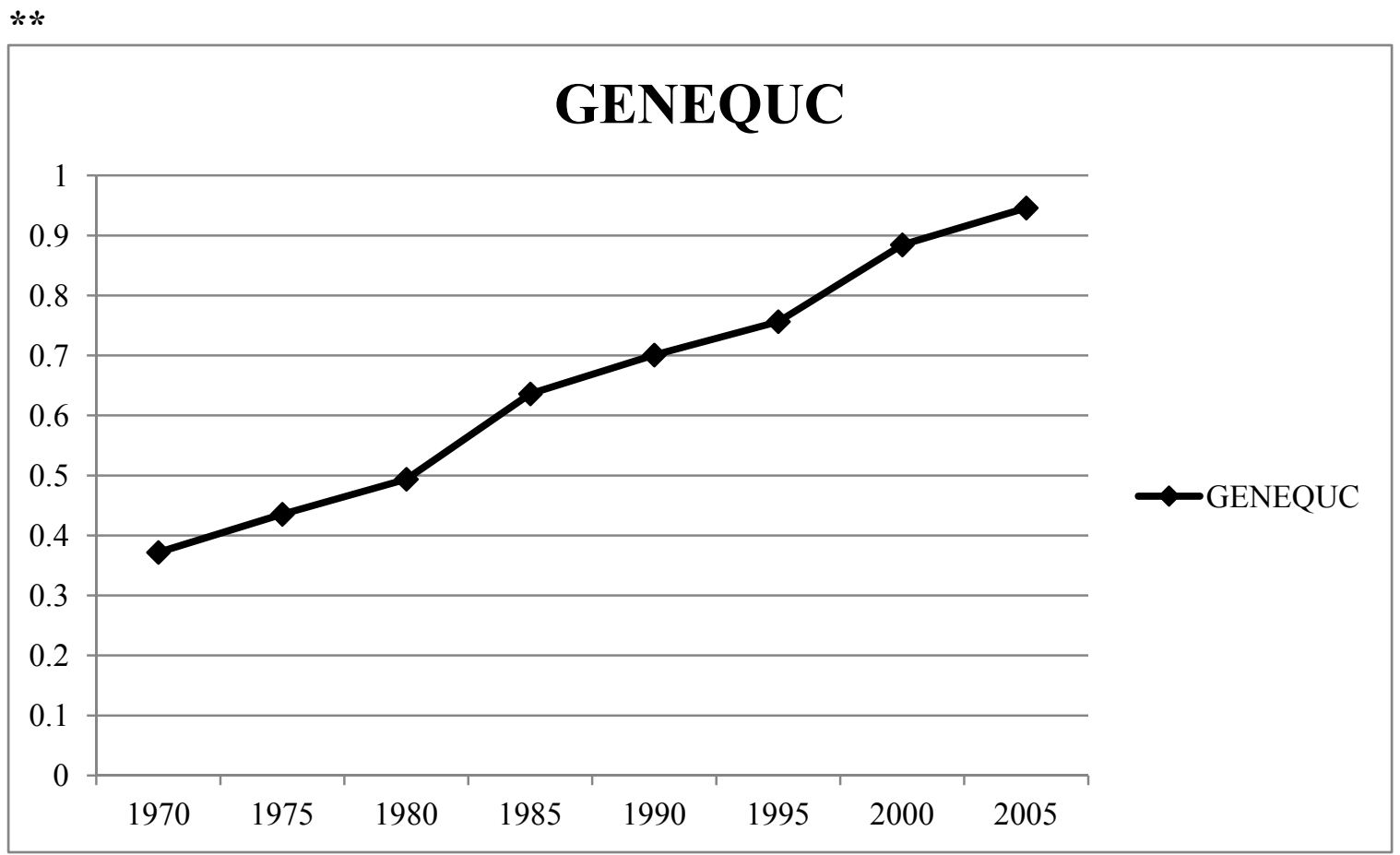

Figure 4.Time trend of gender equity variable: GENEQUC. This figure shows the average development over the period for selected countries.

Attainment. The Education Attainment variable attempts to capture the efficiency and quality of education using two measures, the percentage of the population 15 years and older that have attained higher education (ATTAINP) and the average years of higher education for the same demographic (ATTAINY). This data areavailable at five year intervals (1970 to 2005). Figure 5 shows the average for the countries in the study for this period. 


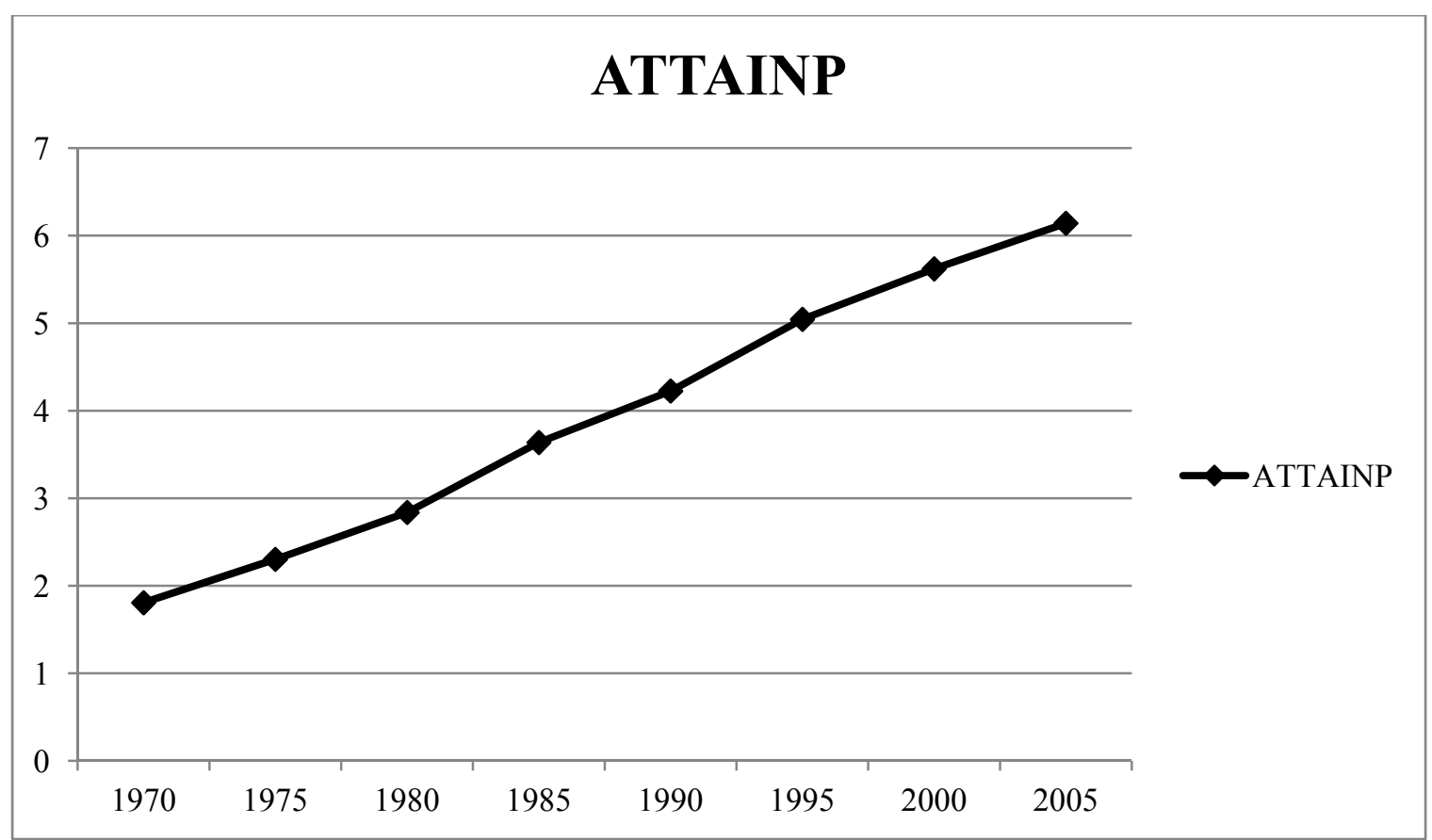

Figure 5. Time trend of educational attainment variables for selected countries: ATTAINP. This figure shows the average development in percentage of population 15 years and over attaining tertiary education over the period for selected countries.

The trend for both these statistics is positive with ATTAINP showing a threefold increase over the period indicating that the percentage of the population attaining higher education increased from an average of about $2 \%$ to $6 \%$. As expected the variation among the countries fluctuated ranging from an increase from 3.6\% for Japan in 1970 to $20.6 \%$ in 2005 , to a decrease for Zimbabwe from 1.1 to 0.4 over the same period. ATTAINY also increased by a similar threefold increase overall with the number of years of schooling increasing from 0.1 years to 0.3 years. 


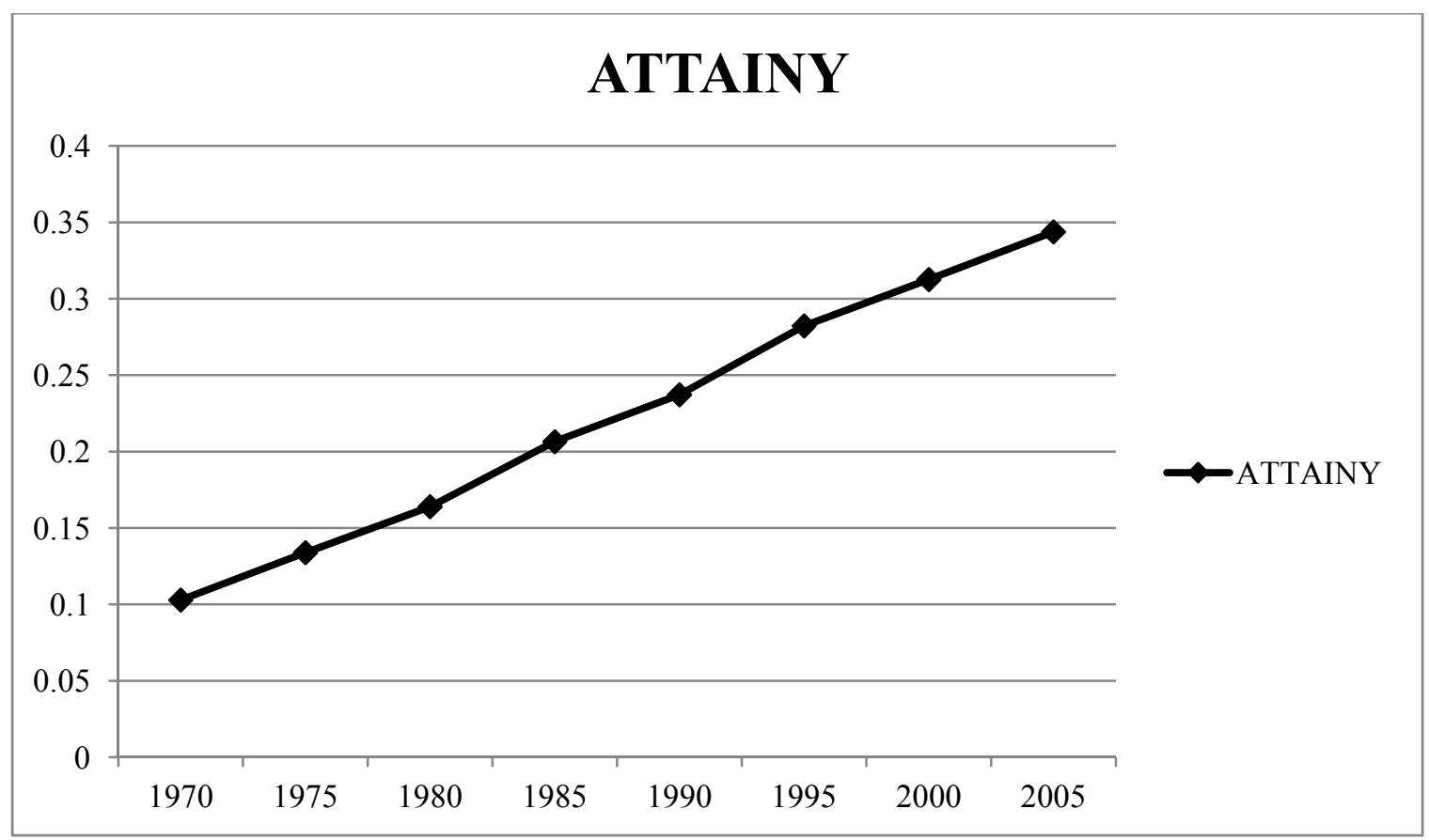

Figure 6. Time trend of educational attainment variables for selected countries:

ATTAINY. This figure shows the average development in average years of tertiary education of the population education over the period for selected countries.

Participation. The participation variable provides an indicator of how well people are able to participate in the education provided in their respective countries. For this study it is measured as the higher education gross enrollment ratio. The gross enrollment ratio is calculated based on the number of students in the higher education age group who are enrolled as a percentage of the country's population of the same age.

The trend for participation in higher education is a positive one increasing from an average of $7 \%$ in the 1970 s to about $40 \%$ in 2009 , an increase of over $500 \%$ as illustrated in the Figure 7. However, it does appear that there has been some slow down in participation starting in the 1990 s. 


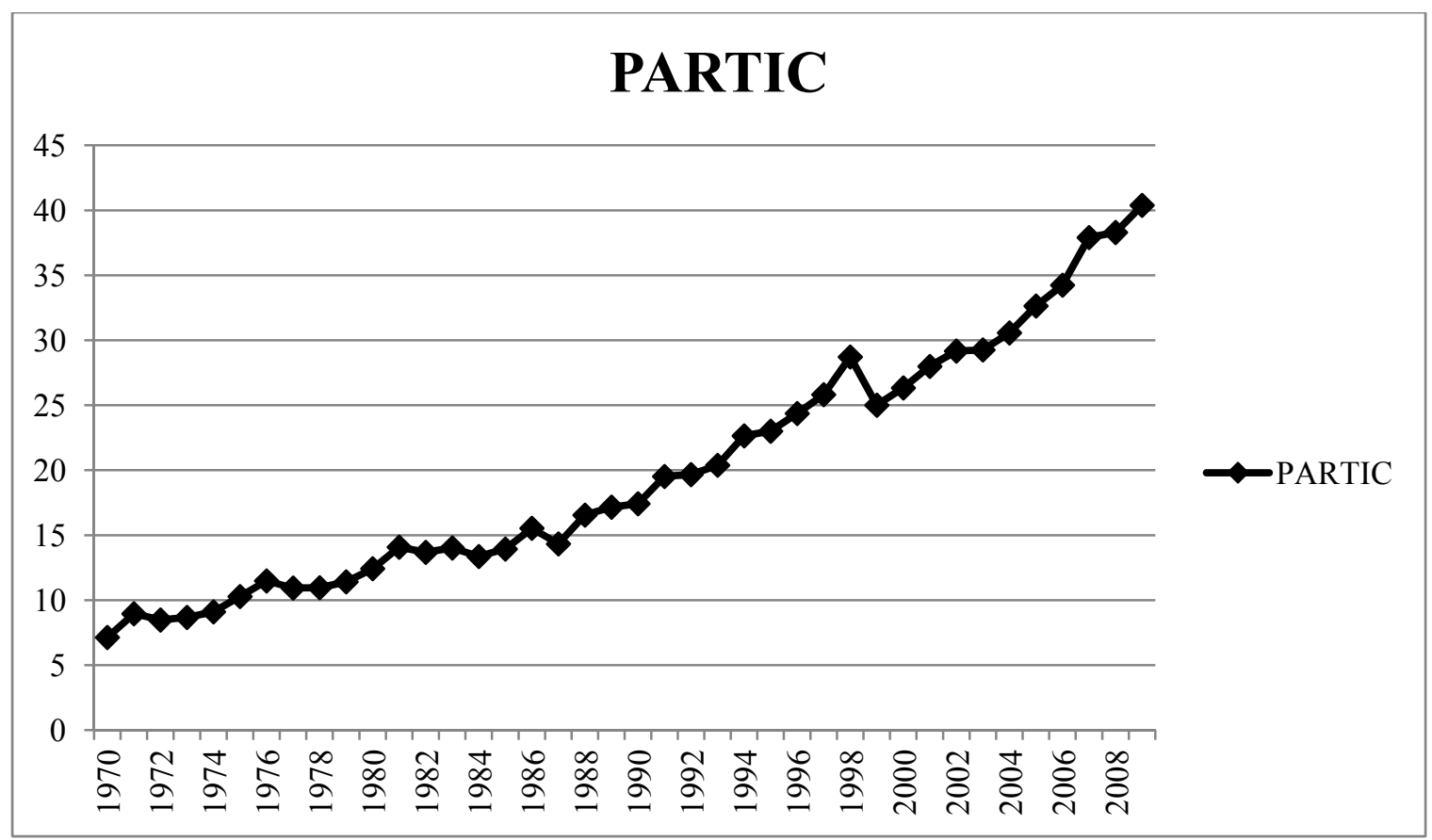

Figure 7. Time trend of participation variable for selected countries: PARTIC. This figure shows the average development in the gross enrollment ratio in higher education for selected countries over the period.

\section{Globalization Indicators.}

For the purpose of this paper, globalization is measured using the KOF Index of globalization. The choice of this index is a reflection of the multidimensional nature of globalization, a broad concept that cannot be captured by a single measure. The KOF index captures the economic, political, cultural and technological dimensions of globalization. The technological and cultural indices are sub-indices of KOF's social dimension (b. ii) Data on Information Flows and (b. iii) Data on Cultural Proximity respectively. The variables that comprise the index and their respective weights are shown in Appendix B. The study also uses two proxies of globalization suggested in the literature, trade as measured by the sum of imports and exports as a share of GDP (TRADE) and inflows of foreign direct investment as a share of GDP (FDI). 
Trends in globalization over the 1970 to 2009 period. This section examines the trends in globalization over the period 1970 to 2009 for the three globalization indicators adopted in the study (KOF, trade and foreign direct investment).

KOF and its dimensions. Since the 1970s there has been a progressive upward trend in the KOF Globalization Index and its dimensions - economic, political, technological and cultural but the cultural dimension lags behind the other three. There is a distinctive heightening in all the dimensions in the 1990s after the end of the Cold War. Another distinctive phase identified beginning the early 2000 which coincides with the bursting of the Information Technology bubble in 2000-1, the terrorist attack of 9-11 and the global economic and financial crisis which began in 2007. This phase has seen a slowdown in the pace of globalization and for the economic globalization index a decline.

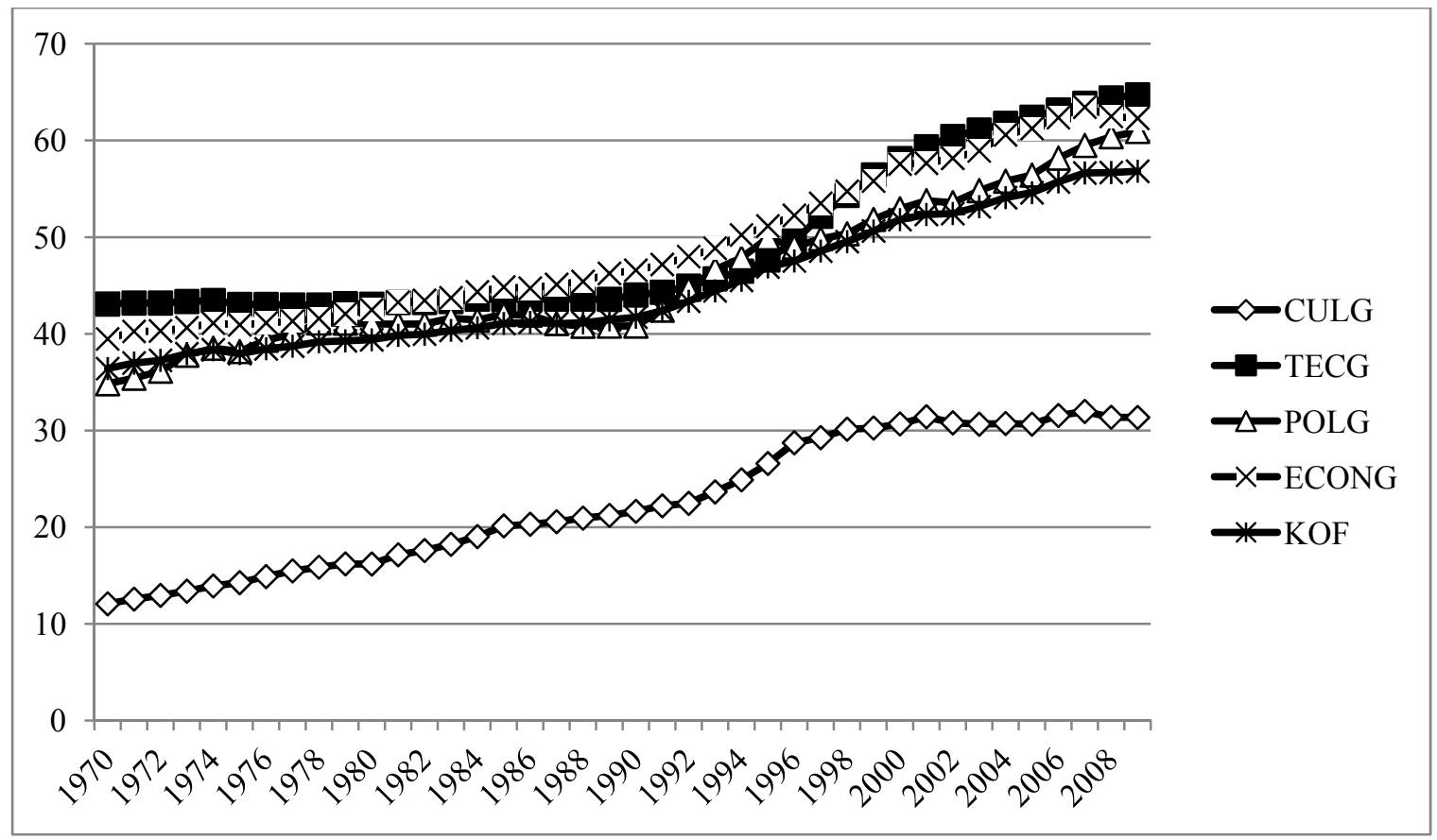

Figure 8. Time trend of the KOF globalization index and its dimensions for countries for which data are available in a given year. This figure show average development over the period.

\section{Trade.}




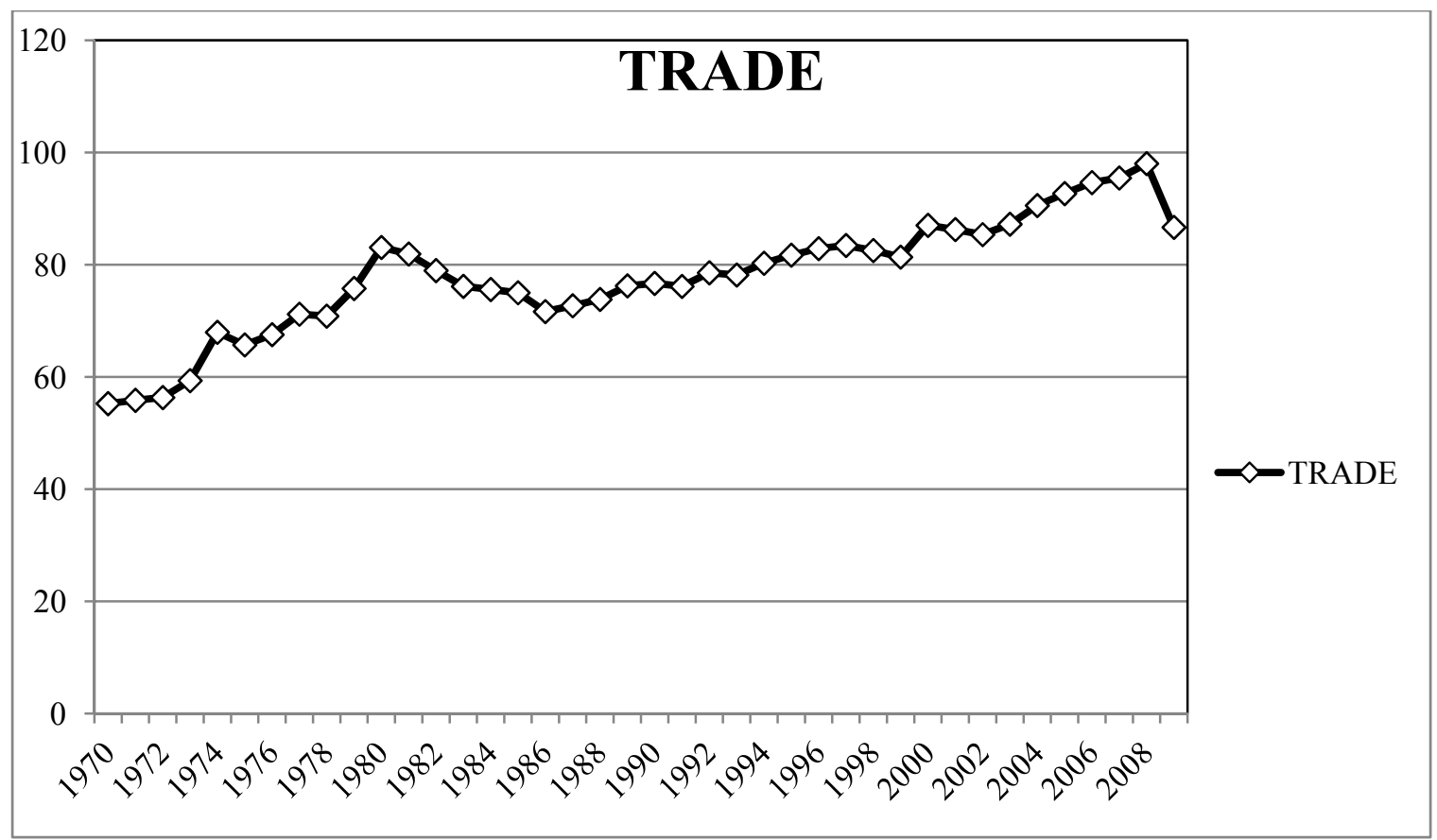

Figure 9. Time trend of the TRADE globalization index for countries for which data are available in a given year. This figure show average development over the period.

\section{Foreign Direct Investment (FDI).}

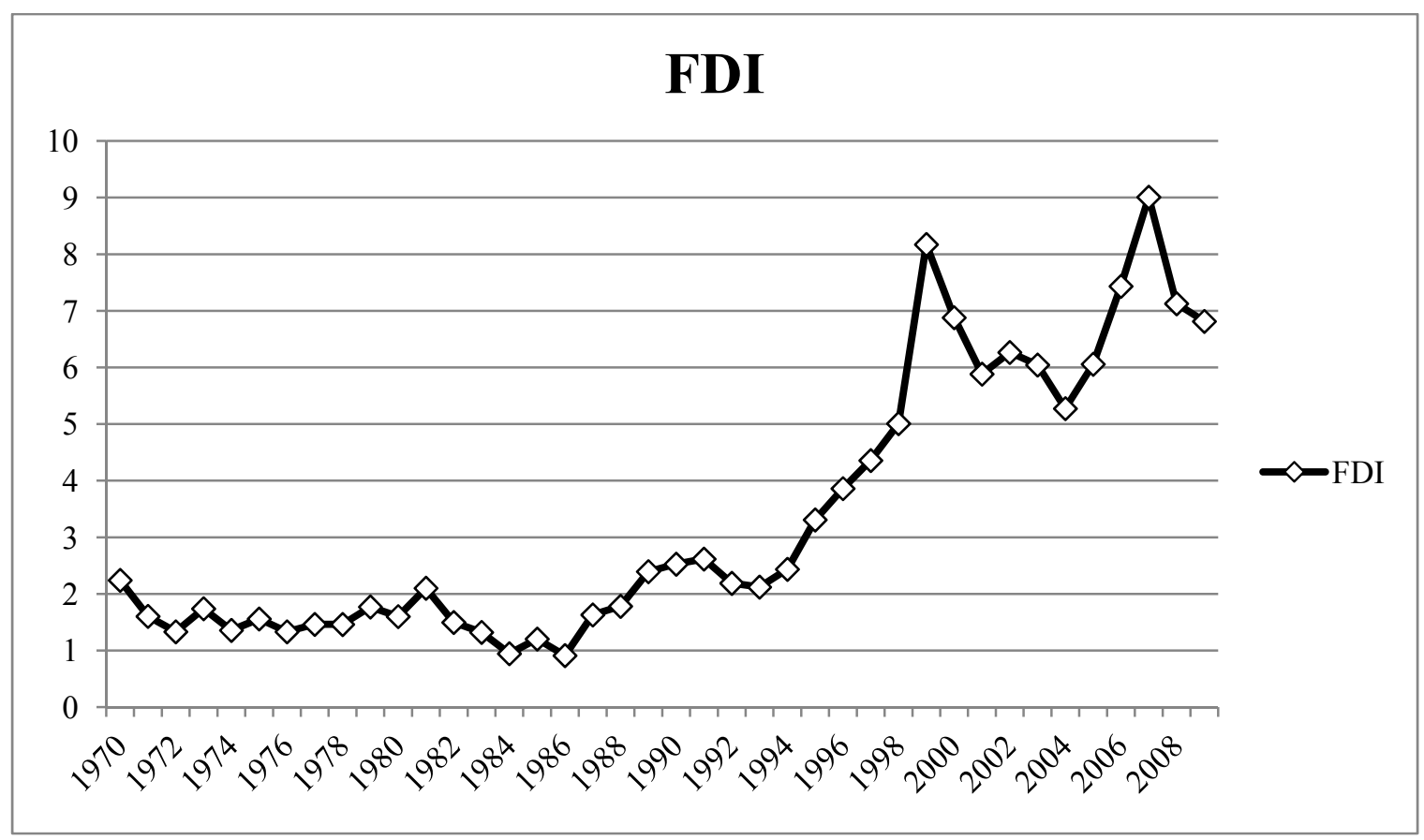

Figure 10. Time trend of the FDI globalization index for countries for which data are available in a given year. This figure show average development over the period. 
The averages of the three measures of globalization used in this study, the KOF globalization index and the traditional measures of globalization (TRADE, FDI), are shown in Figure 11. The diagram shows that globalization has been increasing over the 1970 to 2009 period with the trade and KOF index showing similar increases. The FDI variable however which showed little growth in the 1970s and actually declined in the 1980s, has showed noticeable increases since the early 1990s.

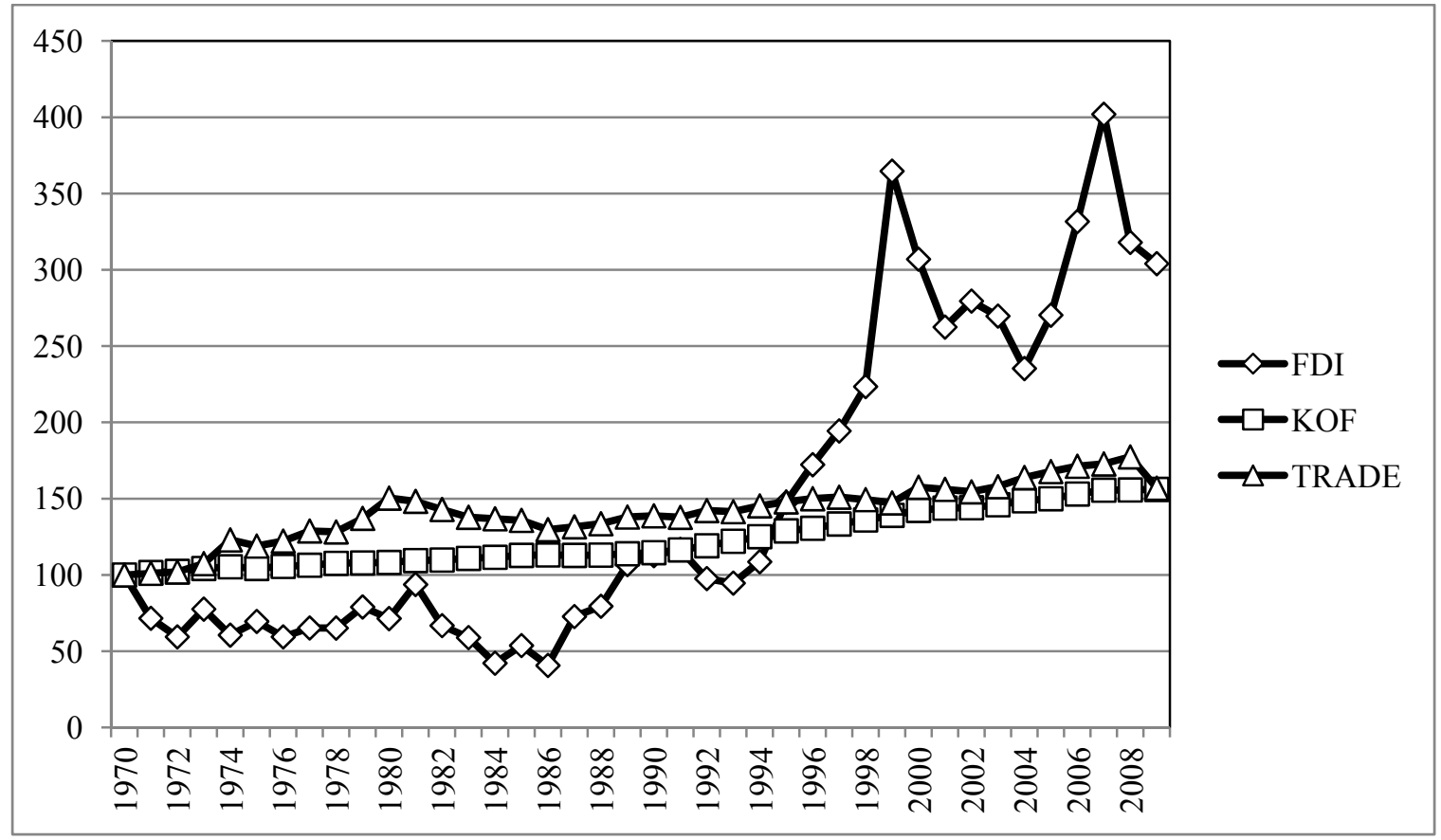

Figure 11. Average development of globalization measures: FDI, TRADE, KOF $(1970=$ 100).

\section{Summary Statistics}

Descriptive statistics (mean, range, standard deviation) for the variables used in the study are presented in Appendix D for each of the five year periods from 1970 to 2009 for all the countries included in this research study. The variables, their descriptions and sources are presented in Appendix A. 


\section{Results}

\section{Results Pearson Correlation}

To give an indication of the crude associations between KOF and its dimensions with the higher education indicators, the Pearson's correlations are given in Table 2 (for the period 1970 to 2009 ). 
Table 2

Correlation matrices: globalization and higher education indicators.

\begin{tabular}{|l|l|l|l|l|}
\hline Indicators & SPENDTOT & SPENDGDPPC & PARTIC & GENEQUGER \\
\hline KOF & .748 & -.823 & .984 & .935 \\
\hline \multicolumn{5}{|c|}{ KOF Dimensions } \\
\hline Economic & .745 & -.834 & .985 & .942 \\
\hline Political & .785 & -.828 & .981 & .933 \\
\hline Cultural & .785 & -.895 & .955 & .974 \\
\hline Technological & .634 & -.704 & .937 & .837 \\
\hline
\end{tabular}

Note: $N=40$. GENEQUC, ATTAINY and ATTAINP were not included because data are available only every five years.

The results show that the globalization indicator (KOF) has a statistically significant positive correlation (at $\alpha=0.05$ ) with all the selected higher education indicators $(.748, .984, .935$ respectively) with the exception of spending per student as a percentage of GDP per capita (SPENDGDPPC). Taking a closer look at the individual dimensions of KOF, the results reveal that the dimensions also have significant positive correlation (at $\alpha=0.05$ ) with the higher education indicators again with the exception of SPENDGDPPC. The correlations between the higher education indicators and the economic, political and cultural dimensions are particularly strong. It should however be noted that the sample size is only forty.

To give an indication of the crude associations between $\mathrm{KOF}$ and the other globalization indicators, the Pearson's correlations are given in Table 3.

Table 3.

Correlation matrices: globalization indicators

\begin{tabular}{|l|l|l|l|}
\hline Globalization & Trade & FDI & KOF \\
\hline Trade & 1 & .755 & .871 \\
\hline FDI & .755 & 1 & .935 \\
\hline KOF & .871 & .935 & 1 \\
\hline
\end{tabular}

Note: $\mathrm{N}=40$. 
The results show that the globalization indicator (KOF) has a statistically significant positive correlation (at $\alpha=0.05$ ) with all the selected proxies of globalization. The absolute degree of correlation varies between 75 and $93 \%$ perhaps an indicator of the difficulties associated with measuring a concept like globalization.

\section{Hypothesis 1: Spending on higher education and globalization}

\section{Results simple linear regression}

To address hypothesis 1 , bi-variate regression analyses using educational spending as the dependent variable and globalization as the explanatory variable (measured by the KOF index) were carried out. Two measures of educational spending were adopted, spending per student per capita (SPENDGDPCAP) and government spending on higher education (SPENDTOT)). This procedure was repeated for each time period. Tables 4 and 5 show the results for each time period.

From 1970 on I observed a moderate and significant negative relationship between KOF and SPENGDPCAP. The $R^{2}$ s are moderate to large ranging from .16 to .26. To give an indication of the crude associations between the globalization index (KOF) and SPENDGDPPCAP, the Pearson's correlations are shown in column 2 of

Table 4 . The results show that the KOF index has a strong statistically significant but negative relationship with SPENDGDPCAP. 
Table 4

Pearson Correlation and Bi-variate Regression Results: Higher education spending and KOF (Spending - SPENDGDPPCAP)

Table 4 Pearson Correlation and Bi-variate Regression Results: Higher education spending and KOF(Spending

\begin{tabular}{|l|l|l|l|l|}
\hline Period & $\mathrm{R}$ & $\mathrm{B} \mathrm{KOF}$ & $R^{2}$ & $N$ \\
\hline $1970-1974$ & $-.47^{* *}$ & $-25.42^{* *}$ & $.22^{* *}$ & 48 \\
\hline $1975-1979$ & $-.51^{* *}$ & $-21.69^{* *}$ & $.26^{* *}$ & 64 \\
\hline $1980-1984$ & $-.50^{* *}$ & $-14.18^{* *}$ & $.25^{* *}$ & 72 \\
\hline $1985-1989$ & $-.42 * *$ & $-8.97^{* *}$ & $.18^{* *}$ & 73 \\
\hline $1990-1994$ & $-.50^{* *}$ & $-7.31^{* *}$ & $.25^{* *}$ & 67 \\
\hline $1995-1999$ & $-.41^{* *}$ & $-7.06^{* *}$ & $.17^{* *}$ & 77 \\
\hline $2000-2004$ & $-.40^{* *}$ & $-6.56^{* *}$ & $.16^{* *}$ & 80 \\
\hline $2005-2009$ & $-.39 * *$ & $-3.76^{* *}$ & $.16^{* *}$ & 84 \\
\hline
\end{tabular}

Notes: ${ }^{*} p<.05 .{ }^{* *} p<.01 . R-$ correlation coefficient. Unstandardized coefficients. Dependent variable: SPENDGDPCAP - spending on higher education per student as a percentage of GDP per capita.

Globalization variable - KOF (index of globalization).

Table 5 shows that the relationship between KOF and SPENTOT has been relatively weak over the period. The coefficients are non-significantnon-significant throughout. The $R^{2}$ ranges from .00 to .04 revealing an explained variance that is rather low. KOF enters positively in the equation with the exception of the mid 1970s to early 1980s. To give an indication of the crude associations between the globalization index (KOF) and SPENDTOT, the Pearson's correlations are shown in column 2 in Table 5. The table shows that SPENDTOT has a weak correlation with globalization and it is not statistically significant. The sign however is mostly positive. 
Table 5

Pearson Correlation and Bi-variate Regression Results: Higher education spending and KOF (Spending - SPENDTOT)

Table 5 Pearson Correlation and Bi-variate Regression Results: Higher Education Spending and KOH

\begin{tabular}{|l|l|l|l|l|}
\hline Period & $\mathrm{R}$ & $\mathrm{B}$ KOF & $R^{2}$ & $N$ \\
\hline $1970-1974$ & .00 & .00 & .00 & 73 \\
\hline $1975-1979$ & -.16 & -.08 & .02 & 80 \\
\hline $1980-1984$ & -.15 & -.08 & .02 & 81 \\
\hline $1985-1989$ & .02 & .01 & .00 & 79 \\
\hline $1990-1994$ & .14 & .06 & .02 & 87 \\
\hline $1995-1999$ & .16 & .07 & .03 & 91 \\
\hline $2000-2004$ & .15 & .07 & .02 & 71 \\
\hline $2005-2009$ & .19 & .09 & .04 & 72 \\
\hline
\end{tabular}

Notes: ${ }^{*} p<.05 .{ }^{* *} p<.01 . R$ - correlation coefficient. Unstandardized coefficients. Dependent variable: SPENDTOT - spending on higher education as a percentage of total government education spending. Globalization variable - KOF (index of globalization).

The models show that the education spending variables are capturing different aspects of education spending. For SPENDGDPPCAP, an increase in the globalization index (KOF) by one point would decrease spending per student per capita by between .39 and .50 percentage points over the period. On the other hand, globalization has no significant impact on the SPENDTOT model.

\section{Robustness - Alternative Measures of Globalization}

In a test for the robustness of the results, I also computed the coefficients for two alternative measures of globalization used in the literature, foreign direct investment (FDI) and trade (TRADE). The results are presented in Tables 6 and 7. The results for the SPENDGDPCAP variable and its relationship to FDI and TRADE are similar to those for KOF in that the coefficient is largely negative over the period. They were however not largely significant and had a lower variance (.00 to 02$)$. For the other spending variable, SPENDTOT, the results were not stable with the coefficient for the FDI variable being negative as opposed to positive in the KOF analysis. However, only two periods (1990- 
1994, 2000-2004) were significant with an $R^{2}$ of .05and .06, respectively. For the TRADE variable however the result was largely positive in keeping with the earlier finding with the KOF variable. This variable was however not significant for the entire period. For both alternative measures of globalization, the variance was low over the period, .00 to .06 for FDI and .00 to .03 for TRADE.

The results of the test for robustness reveal that the results are not stable. The globalization coefficient for the SPENDGDPPCAP model is no longer significant although the sign remained negative. For the SPENDTOT model there was a change in sign for the FDI measure of globalization however the globalization variable remained non-significantnon-significant. 
Table 6

Bi-variate Regression Results: Higher education spending and alternative globalization indicators (Spending - SPENDGDPPCAP)

Table 6 Bi-variate Regression Results: Higher Education Spending and Alternative Globalization Indicators

\begin{tabular}{|l|l|l|l|l|l|l|}
\hline Period & $B$ FDI & $R^{2}$ & $N$ & $\begin{array}{l}B \\
\text { TRADE }\end{array}$ & $R^{2}$ & $N$ \\
\hline $1970-1974$ & -3.68 & .00 & 33 & .13 & .00 & 48 \\
\hline $1975-1979$ & -3.76 & .00 & 61 & -1.76 & .02 & 65 \\
\hline $1980-1984$ & -12.64 & .01 & 68 & -1.05 & .01 & 74 \\
\hline $1985-1989$ & -5.58 & .01 & 70 & -.44 & .00 & 74 \\
\hline $1990-1994$ & -16.85 & .01 & 65 & $-7.43^{* *}$ & $.24 * *$ & 67 \\
\hline $1995-1999$ & 12.41 & .02 & 76 & -.60 & .01 & 77 \\
\hline $2000-2004$ & -5.14 & .00 & 82 & .00 & -.28 & 80 \\
\hline $2005-2009$ & -2.6 & .01 & 84 & .19 & .00 & 84 \\
\hline
\end{tabular}

Notes: $* p<.05 .{ }^{* *} p<.01$. Unstandardized coefficients. Dependent variable: SPENDGDPCAP - spending on higher education per student as a percentage of GDP per capita. Globalization variables: FDI - foreign direct investment, TRADE -trade in goods.

Table 7

Bi-variate Regression Results: Higher education spending and alternative globalization indicators (Spending - SPENDTOT)

Table 7 Bi-variate Regression Results: Higher Education Spending and Alternative Globalization Indicators

\begin{tabular}{|l|l|l|l|l|l|l|}
\hline Period & $B$ FDI & $R^{2}$ & $N$ & $\begin{array}{l}B \\
\text { TRADE }\end{array}$ & $R^{2}$ & $N$ \\
\hline $1970-1974$ & -.18 & .00 & 46 & -.03 & .01 & 64 \\
\hline $1975-1979$ & -.27 & .02 & 73 & -.03 & .02 & 75 \\
\hline $1980-1984$ & -.40 & .01 & 77 & .00 & .00 & 80 \\
\hline $1985-1989$ & -.13 & .00 & 77 & .01 & .00 & 78 \\
\hline $1990-1994$ & $-.63^{*}$ & $.05^{*}$ & 84 & .06 & .02 & 89 \\
\hline $1995-1999$ & -.18 & .01 & 89 & .02 & .01 & 89 \\
\hline $2000-2004$ & $.55^{*}$ & $.06^{*}$ & 72 & .03 & .03 & 70 \\
\hline $2005-2009$ & -.03 & .01 & 73 & .00 & .00 & 72 \\
\hline
\end{tabular}

Notes: ${ }^{*} p<.05 .{ }^{* *} p<.01$. Unstandardized coefficients. Dependent variable: SPENDTOT - spending on higher education as a percentage of total government education spending. Globalization variables: FDI foreign direct investment, TRADE - trade in goods.

\section{Multiple Regression Analysis}

In the subsequent step, various control variables (political, demographic,

economic) are introduced while keeping the principal explanatory variable, globalization, in the equation. The results are shown in Tables 8 and 9. The choice of the variables was 
based on the literature review as discussed in Chapter 2. The following control variables were adopted for the study.

GDP per capita (GDPPCAP) is an indicator of the level of economic

development. It is included to account for the possible effects a country's income level is related to educational expenditure.

Economic growth (GROWTH) is an indicator of economic volatility and is included to account for its effect on government spending and by extension government spending on higher education.

Capital stock (CAPSTOCK) is included as a control in the model as it has been shown in some studies that government's investment in education may depend on the skill requirement of the economy.

Democracy (DEMOCRACY) is included to control for the impact of systematic partisan biases in education expenditure.

Population variables to control for higher education population to capture demographic pressures on education spending are also included. These variables are POPSHARE which measures the percentage of population in the higher education age group and PARTIC which measures the gross enrollment rates in higher education.

\section{Explanatory power of the models}

The spending models (SPENDTOT and SPENDGDPCAP) could explain on average between $16 \%$ to $35 \%$ variation of the respective indicators. This is a reasonable fit. The fit for the SPENDGDPCAP model was significant while for the SPENDTOT model it was not. The $R^{2}$ for SPENDGDPCAP ranges from a low of .22 to a high of .45 while that of SPENDTOT is lower ranging from a low .05 to a high of .31 over the 
period. Overall, the $R^{2} \mathrm{~s}$ are higher in comparison to the results for the simple linear regression model. This indicates that the models for education expenditure have been improved with the addition of the controlling variables.

Table 8

Multiple Regression Results: Higher education spending and globalization (KOF) (Spending-SPENDGDPPCAP)

Table 8 Multiple Regression Results: Higher Education Spending and Globalization (KOF)(Spending -

\begin{tabular}{|l|l|l|l|l|l|l|l|l|}
\hline Variable & $1970-$ & $1975-$ & $1980-$ & $1985-$ & $1990-$ & $1995-$ & $2000-$ & $2005-$ \\
& 74 & 79 & 84 & 89 & 94 & 99 & 04 & 09 \\
\hline KOF & .00 & -.12 & -.14 & -.09 & -.39 & $-.51^{*}$ & $-.48^{*}$ & $-.53^{*}$ \\
\hline GDPPCAP & .82 & .20 & .01 & -.10 & .06 & .11 & .09 & .20 \\
\hline CAPSTOCK & -.40 & -.05 & -.08 & .03 & .05 & -.03 & .05 & -.07 \\
\hline GROWTH & .18 & -.05 & .03 & .11 & -.05 & .17 & -.13 & -.18 \\
\hline DEMOCRACY & -.14 & -.16 & .03 & -.17 & -.25 & .17 & .05 & .21 \\
\hline POPSHARE & .05 & -.14 & -.25 & $-.33^{*}$ & -.26 & -.34 & -.28 & .13 \\
\hline PARTIC & $-.91^{*}$ & $-.62^{*}$ & $-.57^{* *}$ & $-.39^{*}$ & -.21 & -.41 & -.33 & -.23 \\
\hline$R^{2}$ & $.45^{*}$ & $.40^{* *}$ & $.39^{* *}$ & $.40^{* *}$ & $.36^{* *}$ & $.31^{* *}$ & $.22^{*}$ & $.27 * *$ \\
\hline$N$ & 36 & 51 & 63 & 63 & 60 & 69 & 72 & 76 \\
\hline
\end{tabular}

Notes: ${ }^{*} p<.05$. ${ }^{* *} p<.01$. Standardized coefficients. Dependent variable: SPENDGDPPCAP - spending on higher education per student as a percentage of GDP per capita. Globalization variable - KOF (index of globalization). Control variables: GDP per capita (GDPPCAP), capital intensity (CAPSTOCK), economic growth (GROWTH), politics (DEMOCRACY), population share in higher education (POPSHARE), gross enrolment in higher education (PARTIC). 
Table 9

Multiple Regression Results: Higher education spending and globalization (KOF) (Spending- SPENDTOT)

Table 9 Multiple Regression Results: Higher Education Spending and Globalization (KOF) (Spending-

\begin{tabular}{|l|l|l|l|l|l|l|l|l|}
\hline Variable & $1970-$ & $1975-$ & $1980-$ & $1985-$ & $1990-$ & $1995-$ & $2000-$ & $2005-$ \\
& 74 & 79 & 84 & 89 & 94 & 99 & 04 & 09 \\
\hline KOF & .02 & -.10 & -.20 & .12 & .17 & .06 & -.20 & .50 \\
\hline GDPPCAP & $-.76^{*}$ & -.15 & .18 & .15 & .25 & $.62^{*}$ & .46 & -.16 \\
\hline CAPSTOCK & -.21 & -.02 & -.09 & -.08 & -.05 & $-.32^{*}$ & $-.36^{*}$ & -.23 \\
\hline GROWTH & $.38^{*}$ & .26 & .21 & .08 & -.05 & .06 & .17 & -.07 \\
\hline DEMOCRACY & $.87^{* *}$ & .08 & -.05 & -.30 & -.33 & .01 & .17 & -.08 \\
\hline POPSHARE & -.13 & .04 & .27 & .18 & .23 & .26 & .22 & -.03 \\
\hline PARTIC & .35 & .16 & .08 & .07 & .17 & -.26 & .14 & -.03 \\
\hline$R^{2}$ & $.31^{*}$ & .09 & .12 & .05 & .12 & .18 & .20 & .22 \\
\hline$N$ & 46 & 52 & 56 & 59 & 66 & 66 & 54 & 54 \\
\hline
\end{tabular}

Notes: ${ }^{*} p<.05 .{ }^{* *} p<.01$. Standardized coefficients. Dependent variable: SPENDTOT - spending on higher education as a percentage of total government education spending. Globalization variable - KOF (index of globalization). Control variables: GDP per capita (GDPPCAP), capital intensity (CAPSTOCK), economic growth (GROWTH), politics (DEMOCRACY), population share in higher education (POPSHARE), gross enrolment in higher education (PARTIC).

\section{Globalization}

The impact of globalization as measured by the KOF index is not significant for all the periods for the SPENDTOT specification of the spending model. This is in keeping with the findings for the simple linear model. However, for the SPENDGDPCAP model it is only significant for the last three periods compared to the simple linear model when it was significant for the entire period. This is an indication that the controlling variables play an important role in the relationship. A one point increase in globalization would decrease spending per student per capita by between .48 and .53 percentage points. Again, similar to the simple linear regression, both specifications maintain their sign with SPENDTOT largely positive and SPENDGDPCAP largely negative.

\section{Control variables}

For the SPENDGDPPCAP specification of the spending model, GDPPCAP, 
is not significant. However, for the SPENDTOT model it is significant for two periods with a negative sign for the 1970-1974 period and positive for the 1995-1999 period. Thus for a one point increase in the globalization index, government expenditure could decline by .76 percentage points or increase by .62 percentage points. CAPSTOCK, which measures the capital intensity of a country is however largely negative and nonsignificant in the SPENDGDPPCAP specification. For SPENDTOT, capital intensity is negative and significant for two periods, 1995 to 2004. A one point increase in capital intensity would decrease government spending on higher education between .32 and .36 percentage points.

Volatility in the economy as measured by GROWTH is largely non-significant in both models however the direction of impact varies. For the SPENDTOT specification, growth is largely positive indicating that education spending is not directly affected by the variability in the economy. However, in terms of spending per student as a percentage of GDP per capita, the finding shows a mixed result with both positive and negative findings.

Democracy which measures the impact of political factors on education spending is largely non-significant for both specifications of the spending model. The results are also mixed for both specifications with both positive and negative associations over the period.

The results with respect to the population variables are also mixed for both specifications of the model. For POPSHARE which measures the population in the higher education age group, the results are non-significant for both spending models. However, in the case of SPENDGDPCAP, impact is largely negative while for 
SPENDTOT, it is the opposite. The enrollment ratio (PARTIC) for higher education was significant in the 1970 to 1989 period for SPENDGDPCAP with a point increase in participation resulting a decrease in spending per student per capita by between .21 and .91 percentage points. For the alternative spending model, SPENTOT, it is nonsignificant for the entire period. The results are also mixed with respect to sign with PARTIC having a largely negative impact for SPENDGDPCAP and positive for SPENDTOT.

\section{Robustness - Alternative Measures of Globalization}

In a test for the robustness of the results, I also computed the coefficients for two alternative measures of globalization used in the literature, foreign direct investment (FDI) and trade (TRADE). The results are presented in Appendix E, Tables 1 to 4. The results for the SPENDGDPCAP variable and its relationship to FDI and TRADE are similar in that the globalization coefficient is significant for only one period, 1975-79 and 1970-74 respectively. They were however positive and had a higher variance, .45 and.52 respectively. For the other spending variable, SPENDTOT, both alternative variables were not significant for the entire period. The results of the test for robustness reveal that the results are not stable for the SPENDGDPPCAP model while for the SPENDTOT model there was a change.

\section{Hypothesis 2: Educational Outcomes}

\section{Results simple linear regression models}

Bi-variate regression analyses with educational outcomes (as measured by attainment, gender equity and participation) as the dependent variable and globalization 
as the explanatory variable (measured by the KOF index) was carried out. This procedure was repeated for each time period. See Tables 10 through 19.

To give an indication of the crude associations between the globalization index, KOF, with the higher education outcome indicators, the Pearson's correlations are given in column 2 of Tables 10,11,14,16 and 18, The results show that the KOF index has a strong statistically significant positive correlation with PARTIC, ATTAINY and ATTAINP. However, for the equity measures, GENEQUC and GENEQUGER, it has a weak correlation and it is not statistically significant.

\section{Attainment}

Tables 10 and 11 show the regression results for each time period for the two measures of higher educational attainment, ATTAINP and ATTAINY and globalization as measured by the KOF index. To give an indication of the crude associations between the globalization index (KOF) and attainment (ATTAINP and ATTAINY) the Pearson's

correlations are shown in column 2 . The table shows that attainment has a strong, positive and significant correlation with globalization.

From 1970 on I observed a relatively strong and significant relationship between globalization and attainment. The results for the educational attainment models are similar and could explain about $37 \%$ to $48 \%$ variation which is a reasonable fit. KOF enters positively so that a one point increase in the globalization index would increase ATTAINP by .09 to .24 percentage points and ATTAINY by an average of .01 percentage points. 
Table 10

Pearson Correlation and Bi-variate Regression Results: Higher education spending and KOF (Attainment - ATTAINP)

Table 10 Pearson Correlation and Bi-variate Regression Results: Higher Education Spending and KOH

\begin{tabular}{|l|l|l|l|l|}
\hline Period & $R$ & $B \mathrm{KOF}$ & $R^{2}$ & $N$ \\
\hline $1970-1974$ & $.61^{* *}$ & $.09^{* *}$ & $.37 * *$ & 107 \\
\hline $1975-1979$ & $.66^{* *}$ & $.11^{* *}$ & $.43^{* *}$ & 110 \\
\hline $1980-1984$ & $.63^{* *}$ & $.12^{* *}$ & $.40^{* *}$ & 113 \\
\hline $1985-1989$ & $.63^{* *}$ & $.14^{* *}$ & $.40^{* *}$ & 113 \\
\hline $1990-1994$ & $.63^{* *}$ & $.15^{* *}$ & $.39 * *$ & 115 \\
\hline $1995-1999$ & $.67^{* *}$ & $.18^{* *}$ & $.45^{* *}$ & 116 \\
\hline $2000-2004$ & $.67^{* *}$ & $.21^{* *}$ & $.44^{* *}$ & 116 \\
\hline $2005-2009$ & $.69^{* *}$ & $.24 * *$ & $.47^{* *}$ & 116 \\
\hline
\end{tabular}

Notes: ${ }^{*} p<.05 .{ }^{* *} p<.01 . R$ - correlation coefficient. Unstandardized coefficients. Dependent variable: ATTAINP - Percentage of population 15 years and over attaining education at the tertiary level. Control variable - KOF (index of globalization).

Table 11

Pearson Correlation and Bi-variate Regression Results: Higher education spending and KOF (Attainment - ATTAINY)

Table 11 Pearson Correlation and Bi-variate Regression Results: Higher Education Spending and KOB

\begin{tabular}{|l|l|l|l|l|}
\hline Period & $R$ & $B$ KOF & $R^{2}$ & $N$ \\
\hline $1970-1974$ & $.61^{* *}$ & $.01^{* *}$ & $.37^{* *}$ & 107 \\
\hline $1975-1979$ & $.65^{* *}$ & $.01^{* *}$ & $.42^{* *}$ & 110 \\
\hline $1980-1984$ & $.62^{* *}$ & $.01^{* *}$ & $.38^{* *}$ & 113 \\
\hline $1985-1989$ & $.63^{* *}$ & $.01^{* *}$ & $.39^{* *}$ & 113 \\
\hline $1990-1994$ & $.63^{* *}$ & $.01^{* *}$ & $.39^{* *}$ & 115 \\
\hline $1995-1999$ & $.68^{* *}$ & $.01^{* *}$ & $.46^{* *}$ & 116 \\
\hline $2000-2004$ & $.68^{* *}$ & $.01^{* *}$ & $.46^{* *}$ & 116 \\
\hline $2005-2009$ & $.69^{* *}$ & $.01^{* *}$ & $.48^{* *}$ & 116 \\
\hline
\end{tabular}

Notes: ${ }^{*} p<.05 .{ }^{* *} p<.01 . R$ - correlation coefficient. Unstandardized coefficients. Dependent variable: ATTAINY - Average years of tertiary schooling of the population. Control variable - KOF (index of globalization).

\section{Robustness - Alternative Measures of Globalization}

In a test for the robustness of the results, I also computed the coefficients for two alternative measures of globalization used in the literature, foreign direct investment (FDI) and trade (TRADE). The results are presented in Tables 12 to 13. The explained variance for both measures of attainment and the alternatives are very low, averaging 
between .00 and .01 and are largely non-significant perhaps an indication that the different measures of globalization are measuring different things. The only exception is the 1990 to 1994 period for both specifications of attainment where the trade globalization coefficients are significant, .16 (ATTAINP) and .01 (ATTAINY), respectively. The results for the alternative globalization measures are therefore not stable.

Table 12

Bi-variate Regression Results: Higher education attainment and alternative globalization indicators (Attainment-ATTAINP)

Table 12 Bi-variate Regression Results: Higher Education Attainment and Alternative Globalization Indicators

\begin{tabular}{|l|l|l|l|l|l|l|}
\hline Period & $B$ FDI & $R^{2}$ & $N$ & $\begin{array}{l}B \\
\text { TRADE }\end{array}$ & $R^{2}$ & $N$ \\
\hline $1970-1974$ & .02 & .00 & 68 & -.00 & .01 & 96 \\
\hline $1975-1979$ & .02 & .00 & 98 & -.00 & .01 & 101 \\
\hline $1980-1984$ & .04 & .00 & 104 & -.00 & .00 & 112 \\
\hline $1985-1989$ & .05 & .00 & 109 & -.00 & .00 & 113 \\
\hline $1990-1994$ & .03 & .00 & 115 & $.16^{* *}$ & $.43^{* *}$ & 117 \\
\hline $1995-1999$ & .02 & .00 & 115 & .00 & .00 & 116 \\
\hline $2000-2004$ & .01 & .01 & 117 & .00 & .00 & 116 \\
\hline $2005-2009$ & .01 & .00 & 117 & .01 & .00 & 117 \\
\hline
\end{tabular}

Notes: $* p<.05 . * * p<.01$. Unstandardized coefficients. Dependent variable: ATTAINP - spending on higher education as a percentage of total government education spending. Globalization variables: FDI foreign direct investment, TRADE -trade in goods.

Table 13

Bi-variate Regression Results: Higher education attainment and alternative globalization indicators (Attainment-ATTAINY)

Table 13 Bi-variate Regression Results: Higher Education Attainment and Alternative Globalization Indicators

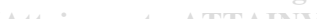

\begin{tabular}{|l|l|l|l|l|l|l|}
\hline Period & $\begin{array}{l}B \\
\text { FDI }\end{array}$ & $R^{2}$ & $N$ & $B$ TRADE & $R^{2}$ & $N$ \\
\hline $1970-1974$ & .00 & .00 & 68 & .00 & .01 & 96 \\
\hline $1975-1979$ & .00 & .00 & 98 & .00 & .01 & 101 \\
\hline $1980-1984$ & .00 & .00 & 104 & .00 & .00 & 112 \\
\hline $1985-1989$ & .00 & .00 & 109 & .00 & .00 & 113 \\
\hline $1990-1994$ & .00 & .00 & 115 & $.01^{* *}$ & $.41^{* *}$ & 117 \\
\hline $1995-1999$ & .00 & .00 & 115 & $\begin{array}{l}-4.7444 \mathrm{E}- \\
005\end{array}$ & .00 & 116 \\
\hline $2000-2004$ & .00 & .00 & 117 & $4.943 \mathrm{E}-005$ & .00 & 115 \\
\hline $2005-2009$ & .00 & .00 & 117 & .00 & .00 & 117 \\
\hline
\end{tabular}

Notes: ${ }^{*} p<.05 .{ }^{* *} p<.01$. Unstandardized coefficients. Dependent variable: ATTAINY - spending on higher education as a percentage of total government education spending. Globalization variables: FDI foreign direct investment, TRADE -trade in goods. 


\section{Participation}

Table 14 shows the regression results for each time period between globalization and higher education participation (KOF, PARTIC). To give an indication of the crude associations between the globalization index (KOF) and participation, the Pearson's correlations are shown in column 2 . The table shows that participation has a strong, positive and significant correlation with globalization.

From 1970 on I observed a relatively strong and significant relationship between globalization and participation. The $R^{2}$ s range from .39 to .61 which are reasonable good fits. However, the explained variance has declined for the last two periods, from a high of .61 in $1995-2004$ to .51 in $2005-09$. Globalization enters positively indicating that a one point increase in the globalization index would increase participation between .36 and 1.17 percentage points.

Table 14

Pearson Correlation and Bi-variate Regression Results: Higher education spending and KOF (Participation - PARTIC)

Table 14 Pearson Correlation and Bi-variate Regression Results: Higher Education Spending and KOF

\begin{tabular}{|l|l|l|l|l|}
\hline Period & $R$ & $B \mathrm{KOF}$ & $R^{2}$ & $N$ \\
\hline $1970-1974$ & $.63^{* *}$ & $.36^{* *}$ & $.39^{* *}$ & 89 \\
\hline $1975-1979$ & $.67^{* *}$ & $.48^{* *}$ & $.45^{* *}$ & 102 \\
\hline $1980-1984$ & $.65^{* *}$ & $.45^{* *}$ & $.42^{* *}$ & 108 \\
\hline $1985-1989$ & $.68^{* *}$ & $.56^{* *}$ & $.46^{* *}$ & 115 \\
\hline $1990-1994$ & $.77^{* *}$ & $.74^{* *}$ & $.59^{* *}$ & 112 \\
\hline $1995-1999$ & $.78^{* *}$ & $.85^{* *}$ & $.61^{* *}$ & 116 \\
\hline $2000-2004$ & $.78^{* *}$ & $1.03^{* *}$ & $.61^{* *}$ & 116 \\
\hline $2005-2009$ & $.71^{* *}$ & $1.17^{* *}$ & $.51^{* *}$ & 113 \\
\hline
\end{tabular}

Notes: ${ }^{*} p<.05 .{ }^{* *} p<.01 . R$ - correlation coefficient. Unstandardized coefficients. Dependent variable: PARTIC - Gross enrollment ratio in higher education. Control variable - KOF (index of globalization).

\section{Robustness - Alternative Measures of Globalization}

The results for the alternative measures of globalization yield different results for the participation measure. The coefficients for both measures (FDI, TRADE) enter 
negatively. FDI is non-significant for the entire period. TRADE however is significant for three periods (1970-74, 1975-1979 and 1990-94) with the 1990-94 period showing the largest effect where a one point increase in TRADE would increase participation by .81 percentage points. This compared to a decrease in participation of .06 percentage points for the 1970 to 1979 period. The explained variation for this period is also low, .05 to $.06 .$, compared to .63 for $1990-94$.

Table 15

Bi-variate Regression Results: Higher education attainment and alternative globalization indicators (Participation - PARTIC)

Table 15 Bi-variate Regression Results: Higher Education Attainment and Alternative Globalization Indicators

\begin{tabular}{|l|l|l|l|l|l|l|}
\hline Period & $B$ FDI & $R^{2}$ & $N$ & $\begin{array}{l}B \\
\text { TRADE }\end{array}$ & $R^{2}$ & $N$ \\
\hline $1970-1974$ & -.31 & .02 & 58 & $-.06^{*}$ & $.06^{*}$ & 81 \\
\hline $1975-1979$ & -.42 & .03 & 90 & $-.06^{*}$ & $.05^{*}$ & 93 \\
\hline $1980-1984$ & -.58 & .03 & 97 & -.03 & .02 & 104 \\
\hline $1985-1989$ & -.30 & .01 & 109 & -.03 & .01 & 114 \\
\hline $1990-1994$ & -.45 & .01 & 110 & $.81^{* *}$ & $.63^{* *}$ & 113 \\
\hline $1995-1999$ & -.07 & .00 & 114 & -.04 & .01 & 115 \\
\hline $2000-2004$ & -.04 & .00 & 118 & .00 & .00 & 115 \\
\hline $2005-2009$ & -.06 & .00 & 113 & -.04 & .00 & 112 \\
\hline
\end{tabular}

Notes: ${ }^{*} p<.05 .{ }^{* *} p<.01$. Unstandardized coefficients. Dependent variable: PARTIC - Gross enrollment ratio in higher education. Globalization variables: FDI - foreign direct investment, TRADE -trade in goods.

\section{Gender equity}

Tables 16 and 17 show the bi-variate regression results for each time period for globalization and gender equity as measured by the variables GENEQUC and GENEQUGER. To give an indication of the crude associations between the globalization index (KOF) and gender equity, the Pearson's correlations are shown in column 2 . The table shows that gender equity has a weak, but largely positive correlation with globalization. The correlations are however only significant for three (GENEQUGER) and four periods (GENEQUC) respectively. 
For the period under review, GENEQUC displayed a relatively weak but positive relationship with globalization. Four periods, 1970 to 1979 and 1990 to 1994, showed significance with a one point increase in the globalization index resulting in an increase in gender equity by .01 on average. The results for the alternative variable, GENEQUGER was also weak and positive. Three periods, 1970 to 1974 and 1995 to 2004, showed significance with a one point increase in the globalization index resulting in an increase in gender equity by .01 on average. The explained variance for both gender equity variables is also very small ranging over the period from .06 to .09 for GENGEQUC and from .05 to .12 for GENEQUGER.

Table 16

Pearson Correlation and Bi-variate Regression Results: Higher education spending and KOF (Gender Equity - GENEQUC)

Table 16 Pearson Correlation and Bi-variate Regression Results: Higher Education Spending and KOF (Gender

\begin{tabular}{|l|l|l|l|l|}
\hline Period & $R$ & $B$ KOF & $R^{2}$ & $N$ \\
\hline $1970-1974$ & $.30^{* *}$ & $.01^{* *}$ & $.09^{* *}$ & 106 \\
\hline $1975-1979$ & $.26^{* *}$ & $.01^{* *}$ & $.07^{* *}$ & 108 \\
\hline $1980-1984$ & .12 & .00 & .01 & 111 \\
\hline $1985-1989$ & .14 & .01 & .02 & 113 \\
\hline $1990-1994$ & $.24^{* *}$ & $.01^{*}$ & $.06^{*}$ & 115 \\
\hline $1995-1999$ & $.27^{* *}$ & $.01^{* *}$ & $.07^{* *}$ & 116 \\
\hline $2000-2004$ & .07 & .00 & .01 & 116 \\
\hline $2005-2009$ & $.16^{*}$ & .01 & .03 & 115 \\
\hline
\end{tabular}

Notes: ${ }^{*} p<.05 .{ }^{* *} p<.01 . R$ - correlation coefficient. Unstandardized coefficients. Dependent variable: GENEQUC - Ratio of females to males completing higher education. Control variable - KOF (index of globalization). 
Table 17

Pearson Correlation and Bi-variate Regression Results: Higher education gender equity and KOF (Gender Equity - GENEQUGER)

Table 17 Pearson Correlation and Bi-variate Regression Results: Higher Education Gender Equity and KOF

\begin{tabular}{|l|l|l|l|l|}
\hline Period & $R$ & $B \mathrm{KOF}$ & $R^{2}$ & $N$ \\
\hline $1970-1974$ & $.34 * *$ & $.01^{* *}$ & $.12^{* *}$ & 73 \\
\hline $1975-1979$ & -.02 & -.00 & .00 & 86 \\
\hline $1980-1984$ & -.03 & -.00 & .00 & 86 \\
\hline $1985-1989$ & .09 & .00 & .01 & 82 \\
\hline $1990-1994$ & .17 & .00 & .03 & 86 \\
\hline $1995-1999$ & $.22^{*}$ & $.01^{*}$ & $.05^{*}$ & 95 \\
\hline $2000-2004$ & $.24 * *$ & $.01^{*}$ & $.06^{*}$ & 106 \\
\hline $2005-2009$ & .12 & .00 & .02 & 103 \\
\hline
\end{tabular}

Notes: ${ }^{*} p<.05 .{ }^{* *} p<.01 . R$ - correlation coefficient. Unstandardized coefficients. Dependent variable: GENEQUGER - Ratio of females to males enrolled in higher education. Control variable - KOF (index of globalization).

\section{Robustness - Alternative Measures of Globalization}

The results for the alternative measures of globalization for the measures of gender equity are similar to those of the KOF in that the coefficients are largely positive and not very significant (Tables 18 and 19). For the GENEQUC specification, FDI was not significant for the entire period while the TRADE variable was significant for three periods (1985-89, 1995-99 and 2000-04). The explained variance for TRADE also remained low ranging from .04 to .07 . For the GENEQUGER specification, FDI was significant for two periods (1975-84) while the TRADE variable was significant for only one period (1990-94). The $R^{2}$ s for the TRADE variable remained low (.04) however that for the FDI variable was slightly higher, ranging from .14 to .22. 
Table 18

Bi-variate Regression Results: Higher education attainment and alternative globalization indicators (Gender equity - GENEQUC)

Table 18 Bi-variate Regression Results: Higher Education Attainment and Alternative Globalization Indicators

\begin{tabular}{|l|l|l|l|l|l|l|}
\hline Period & $B$ FDI & $R^{2}$ & $N$ & $\begin{array}{l}B \\
\text { TRADE }\end{array}$ & $R^{2}$ & $N$ \\
\hline $1970-1974$ & .01 & .02 & 68 & .00 & .02 & 95 \\
\hline $1975-1979$ & .00 & .00 & 97 & .00 & .00 & 100 \\
\hline $1980-1984$ & -.00 & .00 & 102 & .00 & .02 & 110 \\
\hline $1985-1989$ & .00 & .00 & 109 & $.00^{* *}$ & $.07^{* *}$ & 113 \\
\hline $1990-1994$ & .01 & .01 & 115 & .01 & .02 & 117 \\
\hline $1995-1999$ & .00 & .00 & 115 & $.00^{*}$ & $.04^{*}$ & 116 \\
\hline $2000-2004$ & .00 & .00 & 117 & $.00^{* *}$ & $.06^{* *}$ & 116 \\
\hline $2005-2009$ & .00 & .00 & 116 & .00 & .00 & 116 \\
\hline
\end{tabular}

Notes: ${ }^{*} p<.05 .{ }^{* *} p<.01$. Unstandardized coefficients. Dependent variable: PARTIC - Gross enrollment ratio in higher education. Globalization variables: FDI - foreign direct investment, TRADE -trade in goods.

Table 19

Bi-variate Regression Results: Higher education gender equity and alternative globalization indicators (Gender Equity - GENEQUGER)

Table 19 Bi-variate Regression Results: Higher Education Gender Equity and Alternative Globalization Indicators (Gender Equity -GENEOUGER)

\begin{tabular}{|l|l|l|l|l|l|l|}
\hline Period & $B$ FDI & $R^{2}$ & $N$ & $\begin{array}{l}B \\
\text { TRADE }\end{array}$ & $R^{2}$ & $N$ \\
\hline $1970-1974$ & .01 & .01 & 43 & .00 & .00 & 68 \\
\hline $1975-1979$ & $.08^{* *}$ & $.22^{* *}$ & 76 & .00 & .04 & 80 \\
\hline $1980-1984$ & $.09 * *$ & $.14^{* *}$ & 77 & .00 & .03 & 85 \\
\hline $1985-1989$ & .02 & .02 & 77 & .00 & .03 & 82 \\
\hline $1990-1994$ & .01 & .01 & 86 & $.01^{*}$ & $.04 *$ & 89 \\
\hline $1995-1999$ & -.00 & .00 & 94 & .00 & .02 & 94 \\
\hline $2000-2004$ & -.00 & .00 & 108 & .00 & .02 & 105 \\
\hline $2005-2009$ & .00 & .00 & 105 & .00 & .01 & 103 \\
\hline
\end{tabular}

Notes: ${ }^{*} p<.05$. ${ }^{* *} p<.01$. Unstandardized coefficients. Dependent variable: GENEQUGER - Ratio of females to males enrolled in higher education. Globalization variables: FDI - foreign direct investment, TRADE -trade in goods.

\section{Summary of results}

Of the three educational outcomes adopted for the study, attainment and participation, show a strong, positive and significant relationship to globalization as measured by the KOF index. The results for both measures of gender equity are the opposite as the relationship appears weak and largely non-significant. When alternative 
measures of globalization (FDI, TRADE) were computed, the results were not stable for the measures of attainment and participation but remained largely stable for the measures of equity. Thus neither alternative measures of globalization showed a strong relationship to the indicators of higher education.

\section{Results multiple regression models}

In the subsequent step, various control variables (political, demographic, economic) are introduced while keeping the principal explanatory variable, globalization, in the equation. To evaluate hypothesis 2, I ran a regression of globalization as measured by the KOF index on a number of controlling variables that have been identified in the literature as affecting educational outcomes (Chen, 2007). In addition to the variables described earlier for the spending models (GDP per capita, capital stock, and democracy) the following variables are included namely urbanization, secondary school attainment lagged and total education expenditure.

Urbanization (URBAN) is used to control for the positive impact of greater urbanization on accessibility to education and hence higher educational outcomes. Secondary school attainment lagged (SAL, SGERL) is included to control for the population available to educate at the tertiary level. Total education expenditure is included to control for the positive effect of education expenditure on education outcomes. Tables 20 to 24 show the results for each time period for each educational outcome variable.

\section{Explanatory power of the models}

The $R^{2} \mathrm{~s}$ for the participation model (PARTIC) ranged from .63 to .84 over the period. These are very good fits. The $R^{2}$ is the highest in the 1975 to 1979 period $\left(R^{2}=\right.$ 
$.84)$ and the lowest in the 1985 to 1989 period $\left(R^{2}=.63\right)$. The education attainment models (ATTAINP, ATTAINY) could explain on average about $61 \%$ to $64 \%$ variation of the corresponding attainment indicators. These are also very good fits. The fit for ATTAINY which measures the average years of higher education of the population over 15 is slightly higher than that of ATTAINP (percentage of population 15 years and over attaining higher education). The $R^{2}$ for ATTAINY ranges from .51 to .67 while that of ATTAINP ranges from .56 to .70 . The closeness of the $R^{2} \mathrm{~s}$ for both measures is probably an indicator that they are capturing the same variable.

The $R^{2}$ for the two specifications of gender equity (GENEQUC, GENEQUGER) is range from .11 (1990-1994) to .41 (1985-1989) for GENEQUC and from .14 (20052009) to .54 (1985-1989). Both fits are reasonable with GENEQUGER having a slightly higher $R^{2}$. The $R^{2}$ for both specifications of gender equity are also lower than for the attainment and participation models. 
Table 20

Multiple Regression Results: Higher education attainment (ATTAINP) and globalization - KOF

\begin{tabular}{|c|c|c|c|c|c|c|c|c|}
\hline Variable & $\begin{array}{l}1970- \\
74\end{array}$ & $\begin{array}{l}1975- \\
79\end{array}$ & $\begin{array}{l}1980- \\
84\end{array}$ & $\begin{array}{l}1985- \\
89\end{array}$ & $\begin{array}{l}1990- \\
94\end{array}$ & $\begin{array}{l}1995- \\
99\end{array}$ & $\begin{array}{l}2000- \\
04\end{array}$ & $\begin{array}{l}2005- \\
09\end{array}$ \\
\hline $\mathrm{KOF}$ & - & .10 & -.02 & -.23 & -.20 & -.12 & -.05 & .09 \\
\hline GDPPCAP & - & .28 & -.09 & .19 & .31 & $.34^{*}$ & $.37 * *$ & $.33 * *$ \\
\hline URBAN & - & .29 & $.36^{*}$ & .19 & $.35 * *$ & $.37 * *$ & $.30 *$ & $.27 *$ \\
\hline CAPSTOCK & - & -.04 & -.03 & -.19 & -.13 & -.04 & .01 & .04 \\
\hline SAL & - & $.36 * *$ & $.47 * *$ & $.51 * *$ & $.39 * *$ & .19 & .17 & .16 \\
\hline DEMOCRACY & - & -.09 & .11 & .23 & .12 & .20 & $.20 *$ & .09 \\
\hline TOTEDEXP & - & .01 & -.04 & -.10 & -.08 & -.10 & -.12 & -.09 \\
\hline$R^{2}$ & - & $.68 * *$ & $.51 * *$ & $.62 * *$ & $.67 * *$ & $.62 * *$ & $.61 * *$ & $.60 * *$ \\
\hline$N$ & - & 43 & 47 & 45 & 50 & 67 & 78 & 73 \\
\hline
\end{tabular}

Notes: ${ }^{*} p<.05 .{ }^{* *} p<.01 . R-$ correlation coefficient. Standardized coefficients. Dependent variable: ATTAINP - Percentage of population 15 years and over attaining education at the tertiary level. Globalization variable - KOF (index of globalization), Control variables: GDPPCAP -GDP per capita, URBAN - urban population, CAPSTOCK -capital intensity, SAL - population attaining secondary (lagged), DEMOCRACY - popularly based government, TOTEDEXP - total education expenditure.

Table 21

Multiple Regression Results: Higher education attainment (ATTAINY) and globalization - KOF

\begin{tabular}{|l|c|l|l|l|l|l|l|l|}
\hline Variable & $1970-$ & $1975-$ & $1980-$ & $1985-$ & $1990-$ & $1995-$ & $2000-$ & $2005-$ \\
& 74 & 79 & 84 & 89 & 94 & 99 & 04 & 09 \\
\hline KOF & - & .01 & -.14 & -.24 & -.25 & -.15 & -.10 & .06 \\
\hline GDPPCAP & - & .31 & .02 & .21 & $.39^{*}$ & $.38^{* *}$ & $.40^{* *}$ & $.39^{* *}$ \\
\hline URBAN & - & .31 & $.39^{*}$ & .21 & $.36^{* *}$ & $.42^{* *}$ & $.35^{* *}$ & $.37^{* *}$ \\
\hline CAPSTOCK & - & -.04 & -.04 & -.21 & -.12 & .00 & .03 & .07 \\
\hline SAL & - & $.40^{* *}$ & $.51^{* *}$ & $.53^{* *}$ & $.35^{* *}$ & .16 & .16 & .05 \\
\hline DEMOCRACY & - & -.07 & .08 & .19 & .12 & .18 & $.21^{*}$ & .10 \\
\hline TOTEDEXP & - & .03 & -.04 & -.10 & -.09 & -.05 & -.12 & -.10 \\
\hline$R^{2}$ & - & $.70 * *$ & $.56^{* *}$ & $.64^{* *}$ & $.67^{* *}$ & $.64^{* *}$ & $.64^{* *}$ & $.64^{* *}$ \\
\hline$N$ & - & 43 & 47 & 45 & 50 & 67 & 78 & 73 \\
\hline
\end{tabular}

Notes: ${ }^{*} p<.05 .{ }^{* *} p<.01$. Standardized coefficients. Dependent variable: ATTAINY -average years of tertiary schooling of the population. Globalization variable - KOF (index of globalization). Control variables: GDPPCAP -GDP per capita, URBAN - urban population, CAPSTOCK -capital intensity, DEMOCRACY - popularly based government, SAL - population attaining secondary (lagged), TOTEDEXP - total education expenditure. 
Table 22

Multiple Regression Results: Higher education participation (PARTIC) and globalization - KOF

\begin{tabular}{|l|c|l|l|l|l|l|l|l|}
\hline Variable & $\begin{array}{l}1970- \\
74\end{array}$ & $\begin{array}{l}1975- \\
79\end{array}$ & $\begin{array}{l}1980- \\
\text { KOF }\end{array}$ & $\begin{array}{l}1985- \\
89\end{array}$ & $\begin{array}{l}1990- \\
94\end{array}$ & $\begin{array}{l}1995- \\
99\end{array}$ & $\begin{array}{l}2000- \\
04\end{array}$ & $\begin{array}{l}2005- \\
09\end{array}$ \\
\hline GDPPCAP & - & $.50^{*}$ & .30 & .29 & .26 & $.23^{*}$ & .14 & .11 \\
\hline URBAN & - & $.30^{*}$ & $.49^{* *}$ & .09 & .11 & $.19^{*}$ & $.30^{* *}$ & $.29^{*}$ \\
\hline CAPSTOCK & - & .03 & .05 & -.16 & -.09 & -.03 & .07 & -.02 \\
\hline SGERL & - & .09 & .14 & .46 & $.38^{*}$ & $.39^{* *}$ & $.35^{* *}$ & $.41^{* *}$ \\
\hline DEMOCRACY & - & -.05 & -.03 & .07 & .05 & .15 & $.17^{*}$ & -.02 \\
\hline TOTEDEXP & - & -.08 & -.05 & -.14 & -.00 & -.02 & .03 & .10 \\
\hline$R^{2}$ & - & $.84 * *$ & $.71 * *$ & $.63^{* *}$ & $.71^{* *}$ & $.79^{* *}$ & $.80^{* *}$ & $.76^{* *}$ \\
\hline$N$ & - & 41 & 45 & 45 & 49 & 62 & 77 & 77 \\
\hline
\end{tabular}

Notes: $* p<.05 .{ }^{* *} p<.01$. Standardized coefficients. Dependent variable: PARTIC - gross enrollment ratio in higher education. Globalization - KOF (index of globalization). Control variables: GDPPCAP -GDP per capita, URBAN - urban population, CAPSTOCK - capital intensity, DEMOCRACY - popularly based government, SGERL - gross enrollment ratio secondary (lagged), TOTEDEXP - total education expenditure.

Table 23

Multiple Regression Results: Higher education equity (GENEQUC) and globalization (KOF)

\begin{tabular}{|l|c|l|l|l|l|l|l|l|}
\hline Variable & $1970-$ & $1975-$ & $1980-$ & $1985-$ & $1990-$ & $1995-$ & $2000-$ & $2005-$ \\
& 74 & 79 & 84 & 89 & 94 & 99 & 04 & 09 \\
\hline KOF & - & .27 & .30 & .29 & .39 & .15 & -.22 & -.22 \\
\hline GDPPCAP & - & -.51 & $-.63^{*}$ & $-.67^{*}$ & -.16 & -.32 & -.15 & -.23 \\
\hline URBAN & - & .32 & .37 & .26 & -.12 & $.48^{* *}$ & $.46^{*}$ & $.58^{* *}$ \\
\hline CAPSTOCK & - & .13 & .09 & -.11 & -.22 & .13 & .22 & .04 \\
\hline SAL & - & .24 & .31 & .21 & .20 & .06 & -.08 & .06 \\
\hline DEMOCRACY & - & .26 & -.05 & .38 & -.32 & .09 & .20 & .25 \\
\hline TOTEDEXP & - & -.17 & -.28 & -.25 & -.18 & .02 & $.24^{*}$ & .16 \\
\hline$R^{2}$ & - & $.32 *$ & $.34^{*}$ & $.41^{* *}$ & .11 & $.27^{* *}$ & $.19^{*}$ & $.27^{* *}$ \\
\hline$N$ & - & 43 & 47 & 45 & 50 & 67 & 78 & 72 \\
\hline
\end{tabular}

Notes: ${ }^{*} p<.05 .{ }^{* *} p<.01$. Standardized coefficients. Dependent variable: GENEQUC - ratio of females to males completing higher education. Globalization - KOF (index of globalization). Control variables: GDPPCAP - GDP per capita, URBAN - urban population, CAPSTOCK - capital intensity, DEMOCRACY - popularly based government, SAL - population attaining secondary (lagged), TOTEDEXP - total education expenditure. 
Table 24

Multiple Regression Results: Higher education equity (GENEQUGER) and globalization KOF

\begin{tabular}{|l|c|l|l|l|l|l|l|l|}
\hline Variable & $\begin{array}{l}1970- \\
74\end{array}$ & $\begin{array}{l}1975- \\
\text { KOF }\end{array}$ & $\begin{array}{l}1980- \\
84\end{array}$ & $\begin{array}{l}1985- \\
89\end{array}$ & $\begin{array}{l}1990- \\
94\end{array}$ & $\begin{array}{l}1995- \\
99\end{array}$ & $\begin{array}{l}2000- \\
04\end{array}$ & $\begin{array}{l}2005- \\
09\end{array}$ \\
\hline GDPPCAP & - & -.05 & -.50 & -.50 & -.28 & -.31 & .39 & .10 \\
\hline URBAN & - & .09 & -.38 & -.21 & -.05 & -.38 & -.28 & -.02 \\
\hline CAPSTOCK & - & .05 & -.24 & .09 & -.04 & -.02 & -.14 & -.04 \\
\hline SGERL & - & .36 & $1.10^{* *}$ & .71 & $1.07 * *$ & $.59 *$ & .24 & .37 \\
\hline DEMOCRACY & - & -.14 & -.24 & .27 & -.10 & .35. & .07 & -.01 \\
\hline TOTEDEXP & - & -.32 & .06 & -.14 & .12 & .22 & -.07 & -.01 \\
\hline$R^{2}$ & - & .27 & $.48^{*}$ & $.54 *$ & $.52^{* *}$ & $.35^{* *}$ & $.23^{*}$ & .14 \\
\hline$N$ & - & 33 & 31 & 29 & 32 & 50 & 64 & 67 \\
\hline
\end{tabular}

Notes: $* p<.05 .{ }^{* *} p<.01$. Standardized coefficients. Dependent variable: GENEQUGER - Ratio of females to males completing higher education. Globalization - KOF (index of globalization). Control variables: GDPPCAP -GDP per capita, URBAN - urban population, CAPSTOCK -capital intensity, DEMOCRACY - popularly based government, SGERL - gross enrollment ratio secondary (lagged), TOTEDEXP - total education expenditure.

\section{Globalization}

The impact of globalization as measured by the KOF index is not significant for all the periods and for all the education outcome indicators when the controlling factors are included. The change in significance compared to the results of the simple linear regression analysis indicates that the controlling variables play a significant role in the relationship.

\section{Control variables}

GDP per capita (GDPPCAP) was significant and positive for latter half of the period (1990 to 2009) for the attainment model and for the participation model only for the 1995-99 periods. For a one point increase in GDPPCAP, attainment in higher education would increase from between .33 to .37 (ATTAINP) and .39 to .40 (ATTAINY) percentage points. For the GENEQUC model GDPPCAP was significant for two periods (1980 to 1989). The sign however was negative. Thus for a one point 
increase in GDPPCAP, gender equity in higher education would decrease between .63 and .67 percentage points. In the case of GENEQUGER, GDPPCAP is not at all significant.

The coefficients of urbanization in the attainment and participation models are largely positive and significant. For the attainment models, the URBAN coefficient was significant and positive for the 1980 to 1984 and the1990 to 2009 period. A one point increase in urbanization would lead to a increase in attainment ranging from .27 to .37 (ATTAINP) and .35 to .42 (ATTAINY) percentage points. However, in the case of the gender equity models, for GENEQUGER the variable was not significant. Urbanization was significant and positive for the last three periods (1995 to 2009) for the GENEQUC specification indicating that a one point increase in urbanization would increase gender equity in higher education by between .46 and .58 percentage points.

For all the gender equity models, democracy does not have a significant impact. Democracy however is significant and positively related to attainment and participation for the 2000 to 2004 period only. The results indicate that countries that are more democratic for instance have about $20 \%$ more of their population attaining higher education and about 2 more years of higher education for the total population (based on the 2000 to 2004 period).

Chen (2007) notes that "education enrollment and attainment at the ....tertiary level may also be a function of population available from the previous level" (p. 186). Secondary enrollment and attainment variables from the previous five year period were used in the models (SGERL, SAL). While the sign of the association between educational outcomes and school population is largely positive, the results are mixed in terms of 
significance. The results show significance in the early periods for the attainment models (1975 to 1994) and in the latter periods for the participation model (1990 to 2009). For a one point increase in secondary school population, attainment in higher education would increase between .35 and .51 percentage points while participation would increase between .35 and .41 percentage points. For the GENEQUC specification for gender equity, the variable was non-significant though with the expected positive sign. The GENEQUGER specification shown some significance over three periods (1980-84 and 1990-99) and was also positive.

The education expenditure variable (TOTEDEXP) was not significant for the education outcome models with the exception of one period (2000-04) for the GENEQUC model. The sign was positive. For all the education outcome models, the capital intensity of the economy (CAPSTOCK) was non-significant and largely negative.

\section{Robustness - Alternative Measures of Globalization}

The results for the alternative measures of globalization for the measures of gender equity are similar to those of the KOF in that the globalization coefficients are not very significant (See Appendix E, Tables 5 to 14). The only exceptions were the GENEQUC specification, where the coefficient was significant and positive for one period (FDI-1990-94, TRADE - 1985-89) and the participation model which was negative (2000-04). The control variables that were very significant in the KOF model largely remained in the alternative globalization measure model (GDPPCAP, URBAN, SAL/SGERL). DEMOCRACY and TOTEDEXP also maintained their limited significance. CAPSTOCK which was not significant in the KOF globalization measure was significant and negative for one period for the GENEQUC model (1990-94). 


\section{Hypothesis 3}

Globalization has a number of dimensions (economic, technological, cultural, and political, among others). Economic globalization however has been the main focus of research on globalization in education (Chen, 2007; Rudra \& Huggard, 2005). Hypothesis 3 examines the relationship between the individual dimensions of globalization and the public provision of higher education.

To address this hypothesis, the overall KOF index of globalization was replaced by four KOF sub-indices of globalization (economic, technological, cultural, and political). The technological and cultural sub-indices were derived from KOF's Social Globalization sub-index, data on information flows and data on cultural proximity, respectively. See Appendix B for further details about the sub-indices of the KOF Index of Globalization. Regression analysis for the higher education indicators as the dependent and the globalization dimensions as the explanatory variables were first carried out. In a subsequent step the various control variables were introduced (the control variables used in testing this hypothesis are the same as described earlier in this chapter for the spending and educational outcomes models respectively). This was repeated for each time period. The estimation results are presented in Tables 25 through 38.

\section{Education Spending}

For the spending model SPENDGDPCAP, of the four globalization dimensions, it appears that political globalization is the main driving force for expenditure on higher education. As shown in Table 25, the results for the bi-variate regressions show that political globalization is significant throughout with the exception of one period (1975- 
1979). However, the sign is negative indicating that an increase in the index of political globalization by one point reduces spending per student per capita by between 0.33 (2005-2009) and .56 (1990-1994) percentage points over the period.

Technological globalization was also an important driver of globalization for spending on higher education. This dimension of globalization was significant for the first five periods (1970 to 1994). The sign is negative indicating that an increase in the index of technological globalization by one point reduces spending per student per capita between .37 (1985-1989) to .69 (1975-1979) percentage points over the period. Both economic and cultural globalization was non-significant over the period. In terms of the variance explained, the $R^{2}$ s were relatively large ranging from .20 to .41 over the period.

Table 25

Regression Results: Dimensions of globalization and spending on higher education (SPENDGDPPCAP)

Table 25 Regression Results: Dimensions of Globalization and Spending on Higher Education

\begin{tabular}{|c|c|c|c|c|c|c|c|c|}
\hline Variable & $\begin{array}{l}1970- \\
74\end{array}$ & $\begin{array}{l}1975- \\
79\end{array}$ & $\begin{array}{l}1980- \\
84\end{array}$ & $\begin{array}{l}1985- \\
89\end{array}$ & $\begin{array}{l}1990- \\
94\end{array}$ & $\begin{array}{l}1995- \\
99\end{array}$ & $\begin{array}{l}2000- \\
04\end{array}$ & $\begin{array}{l}2005- \\
09\end{array}$ \\
\hline ECONG & .22 & .24 & .01 & .04 & -.01 & .04 & -.14 & -.27 \\
\hline POLG & $-.34 *$ & -.25 & $-.44 * *$ & $-.53 * *$ & $-.56 * *$ & $-.41 * *$ & $-.38 * *$ & $-.33 *$ \\
\hline TECG & $-.51 *$ & $-.69 * *$ & $-.41 *$ & $-.37 *$ & $-.49 * *$ & .42 & -.30 & -.09 \\
\hline CULG & .06 & .12 & .20 & .28 & .38 & .23 & .25 & .11 \\
\hline$R^{2}$ & $.36 * *$ & $.41 * *$ & $.39 * *$ & $.33 * *$ & $.38 * *$ & $.27 * *$ & $.23 * *$ & $.20 * *$ \\
\hline$N$ & 48 & 63 & 68 & 70 & 63 & 70 & 74 & 80 \\
\hline
\end{tabular}

Notes: ${ }^{*} p<.05 .{ }^{* *} p<.01$. Standardized coefficients. Dependent variable: SPENDGDPCAP - spending on higher education per student as a percentage of GDP per capita. Globalization dimensions: ECONG economic globalization, POLG - political globalization, TECG - technological globalization, CULG cultural globalization.

The results of the addition of control variables for economic, political, and demographic factors are shown in Table 26. Political globalization remained significant and negative for most of the period, with a one point increase in political globalization resulting in a decline in spending per student per capita on higher education of between 
.41 and .58 percentage points (1980-2009). Technological globalization, however, was no longer significant. In addition, for one period (1985-1989), cultural globalization was significant and positive. The control variables were also largely non-significant with the exception of POPSHARE, CAPSTOCK and GDPPCAP. POPSHARE was negatively related to SPENDGDPPCAP and was significant for two periods (1980-84, 1985-89). An increase in this variable by one point would decrease spending on higher education between .37 and .45 percentage points. CAPSTOCK and GDPPCAP were significant in the 1970 to 1974 period. CAPSTOCK was negatively related to spending on higher education with a one point increase in capital intensity decreasing spending by .61 percentage points. GDPPCAP on the other hand was positive for that period with a one point increase in the economy's output resulting in an increase in spending on higher education by 1.32 percentage points. In terms of the variance explained, the $R^{2}$ s were relatively large ranging from .31 to .52 over the period.

Table 26

Regression Results: Dimensions of globalization, spending on higher education (SPENDGDPPCAP) and control variables

\begin{tabular}{|l|l|l|l|l|l|l|l|l|}
\hline Variable & $1970-$ & $1975-$ & $1980-$ & $1985-$ & $1990-$ & $1995-$ & $2000-$ & $2005-$ \\
& 74 & 79 & 84 & 89 & 94 & 99 & 04 & 09 \\
\hline ECONG & .31 & .27 & .19 & .01 & .09 & .02 & -.16 & -.25 \\
\hline POLG & -.56 & -.36 & $-.58^{*}$ & $-.55^{*}$ & $-.47^{*}$ & $-.44^{*}$ & $-.48^{*}$ & $-.41^{*}$ \\
\hline TECG & -.10 & -.45 & -.16 & -.12 & -.49 & -.42 & -.31 & -.00 \\
\hline CULG & -.16 & .14 & .22 & $.52^{*}$ & .34 & .10 & .18 & .00 \\
\hline GDPPCAP & $1.32^{*}$ & .15 & -.06 & -.29 & .03 & .05 & -.08 & .15 \\
\hline CAPSTOCK & $-.61^{*}$ & -.08 & -.16 & .08 & .04 & -.03 & -.01 & -.05 \\
\hline GROWTH & .04 & -.11 & -.03 & .06 & -.15 & .12 & -.15 & -.14 \\
\hline DEMOCRACY & -.28 & -.08 & -.00 & -.10 & -.26 & .18 & .02 & .24 \\
\hline POPSHARE & .00 & -.16 & $-.37^{*}$ & $-.45^{*}$ & -.19 & -.34 & -.36 & .05 \\
\hline PARTIC & -.78 & -.16 & $-.35^{*}$ & -.32 & -.06 & -.25 & -.12 & -.29 \\
\hline$R^{2}$ & $.52^{*}$ & $.50^{* *}$ & $.52^{* *}$ & $.52^{* *}$ & $.47 * *$ & $.37 * *$ & $.31^{*}$ & $.31 * *$ \\
\hline$N$ & 36 & 51 & 61 & 63 & 58 & 66 & 68 & 73 \\
\hline
\end{tabular}

Notes: ${ }^{*} p<.05 .{ }^{* *} p<.01$. Standardized coefficients. Dependent variable: SPENDGDPCAP - spending on higher education per student as a percentage of GDP per capita. Globalization dimensions: ECONG - 
economic globalization, POLG - political globalization, TECG - technological globalization, CULG cultural globalization. Control variables: GDPPCAP -GDP per capita, CAPSTOCK -capital intensity, GROWTH - economic growth, DEMOCRACY - popularly based government, POPSHARE - share of population in higher education age, PARTIC - gross enrolment ratio in higher education

For the other spending model, SPENDTOT, the results for the bi-variate regression showed that no globalization dimension was significant (Table 27) in keeping with earlier findings for the overall KOF index. However, when the control variables were introduced, two globalization dimensions were significant for at least one period (Table 28). Economic globalization was significant in the 1970-1974 period while technological globalization was significant in both the 1970-74 and 1995-99 periods. Economic globalization was negatively related to higher education spending, indicating that a one point increase in economic globalization would result in a .57 decline in spending in percentage terms. Technological globalization was however positive with a one point increase in technological globalization resulting in a .54 percentage increase in higher education spending. In terms of variance explained, the $R^{2} \mathrm{~s}$ for those periods were relatively large, .30 and .53 respectively.

Table 27

Regression Results: Dimensions of globalization and spending on higher education (SPENDTOT)

\begin{tabular}{|c|c|c|c|c|c|c|c|c|}
\hline Variable & $\begin{array}{l}1970- \\
74\end{array}$ & $\begin{array}{l}1975- \\
79\end{array}$ & $\begin{array}{l}1980- \\
84\end{array}$ & $\begin{array}{l}1985- \\
89\end{array}$ & $\begin{array}{l}1990- \\
94\end{array}$ & $\begin{array}{l}1995- \\
99\end{array}$ & $\begin{array}{l}2000- \\
04\end{array}$ & $\begin{array}{l}2005- \\
09\end{array}$ \\
\hline ECONG & -.38 & -.34 & -.19 & -.06 & -.27 & -.13 & .31 & .17 \\
\hline POLG & -.03 & .02 & -.02 & .05 & .28 & .17 & .15 & .05 \\
\hline TECG & .33 & .06 & .08 & -.00 & .40 & .44 & .19 & -.06 \\
\hline CULG & .07 & .01 & -.10 & -.01 & -.22 & -.26 & -.37 & .20 \\
\hline$R^{2}$ & .07 & .08 & .04 & .00 & .09 & .07 & .08 & .11 \\
\hline$N$ & 64 & 68 & 69 & 67 & 74 & 76 & 57 & 59 \\
\hline
\end{tabular}

Notes: $* p<.05 . * * p<.01$. Standardized coefficients. Dependent variable: SPENDTOT - spending on higher education as a percentage of total government education spending. Globalization dimensions: ECONG - economic globalization, POLG - political globalization, TECG - technological globalization, CULG - cultural globalization. 
Table 28

Regression Results: Dimensions of globalization, spending on higher education (SPENDTOT) and control variables

Table 28 Regression Results: Dimensions of globalization, spending on higher education (SPENDTOT) and

\begin{tabular}{|l|l|l|l|l|l|l|l|l|}
\hline Variable & $1970-$ & $1975-$ & $1980-$ & $1985-$ & $1990-$ & $1995-$ & $2000-$ & $2005-$ \\
& 74 & 79 & 84 & 89 & 94 & 99 & 04 & 09 \\
\hline ECONG & $-.57^{*}$ & -.26 & -.25 & -.16 & -.25 & -.25 & .040 & .40 \\
\hline POLG & .27 & -.05 & -.01 & .36 & .32 & .26 & .29 & .30 \\
\hline TECG & $.48^{*}$ & .11 & .21 & .30 & .41 & $.54^{*}$ & .33 & .17 \\
\hline CULG & .22 & -.02 & -.26 & -.31 & -.31 & -.53 & -.67 & -.24 \\
\hline GDPPCAP & -.98 & .28 & .32 & .37 & .21 & $.69^{*}$ & .59 & -.06 \\
\hline CAPSTOCK & -.23 & -.03 & -.13 & -.29 & .01 & $-.30^{*}$ & -.34 & -.24 \\
\hline GROWTH & $.54^{*}$ & .31 & .23 & .23 & .03 & .09 & .28 & -.11 \\
\hline DEMOCRACY & $.98^{*}$ & .05 & -.12 & -.43 & -.27 & .01 & .23 & -.02 \\
\hline POPSHARE & -.14 & .16 & .28 & .26 & -.02 & .18 & .20 & .02 \\
\hline PARTIC & .21 & -.11 & .02 & .01 & .06 & -.35 & -.07 & -.18 \\
\hline$R^{2}$ & $.53^{* *}$ & .11 & .15 & .14 & .15 & $.30^{*}$ & .25 & .25 \\
\hline$N$ & 44 & 50 & 54 & 56 & 64 & 62 & 49 & 51 \\
\hline
\end{tabular}

Notes: $* \mathrm{p}<.05 . * * \mathrm{p}<.01$. Standardized coefficients. Dependent variable: SPENDTOT - spending on higher education as a percentage of total government education spending. Globalization dimensions: ECONG - economic globalization, POLG - political globalization, TECG - technological globalization, CULG - cultural globalization. Control variables: GDPPCAP -GDP per capita, CAPSTOCK - capital intensity, GROWTH - economic growth, DEMOCRACY - popularly based government, POPSHARE share of population in higher education age, PARTIC - gross enrolment ratio in higher education.

\section{Education Outcomes}

Attainment. In the analysis for the attainment model ATTAINP, all the dimensions of globalization with the exception of the economic showed some degree of significance over the period (Table 29). The main driver appears to be technological globalization which was significant for first seven periods. The sign is positive indicating that for a one point increase in the index of technological globalization, attainment in higher education as measured by the population attaining higher education would increase between .27 and .55 percentage points over the period. Political globalization was significant between 1970 and 1989 and is also positive indicating that the more politically globalized a country was the greater the attainment in higher education. A one 
point increase in the index of political globalization would increase attainment in higher education between .27 and .31 percentage points.

Table 29

Regression Results: Dimensions of globalization and attainment in higher education (ATTAINP)

\begin{tabular}{|c|c|c|c|c|c|c|c|c|}
\hline Variable & $\begin{array}{l}1970- \\
74\end{array}$ & $\begin{array}{l}1975- \\
79\end{array}$ & $\begin{array}{l}1980- \\
84\end{array}$ & $\begin{array}{l}1985- \\
89\end{array}$ & $\begin{array}{l}1990- \\
94\end{array}$ & $\begin{array}{l}1995- \\
99\end{array}$ & $\begin{array}{l}2000- \\
04\end{array}$ & $\begin{array}{l}2005- \\
09\end{array}$ \\
\hline ECONG & .03 & .03 & -.05 & -.07 & -.18 & -.09 & -.07 & .06 \\
\hline POLG & $.31 * *$ & $.31 * *$ & $.31 * *$ & $.27 * *$ & .18 & .12 & .10 & .11 \\
\hline TECG & $.27 *$ & $.30 *$ & $.38 * *$ & $.43 * *$ & $.55 * *$ & $.45^{* *}$ & $.28 *$ & .21 \\
\hline CULG & $.22 *$ & $.26 * *$ & .16 & .16 & .20 & .29 & $.46 * *$ & $.45 * *$ \\
\hline$R^{2}$ & $.45 * *$ & $.52 * *$ & $.47 * *$ & $.46 * *$ & $.46^{* *}$ & $.49 * *$ & $.49 * *$ & $.53 * *$ \\
\hline$N$ & 100 & 103 & 105 & 105 & 107 & 108 & 107 & 108 \\
\hline
\end{tabular}

Notes: ${ }^{*} p<.05 .{ }^{* *} p<.01$. Standardized coefficients. Dependent variable: ATTAINP - Percentage of population 15 years and over attaining education at the tertiary level. Globalization dimensions: ECONG economic globalization, POLG - political globalization, TECG - technological globalization, CULG cultural globalization.

Cultural globalization was significant for the first two and last two years of the

period. The sign is also positive, indicating that the more culturally globalized a country was the greater the attainment in higher education. A one point increase in the index of cultural globalization would increase attainment in higher education between .22 and .46 percentage points. The explanatory power of the ATTAINP model is also large ranging from .45 (1970-1974) to $.53(2005-2009)$.

When the control variables are introduced (Table 30) none of the globalization dimensions were significant confirming previous estimates which used the overall index of globalization. However, three of the control variables namely GDP per capita (GDPPCAP), urban population (URBAN) and secondary attainment lagged (SAL) were relatively significant. GDPPCAP was positive indicating that improvements in the economy positively influenced attainment in higher education. A one point increase in GDPPCAP would increase attainment by .30 to .35 (1995-2009) percentage points. The greater the urban population (URBAN) and the greater the attainment at the secondary 
level (SAL), the higher will be the attainment in higher education. A one point increase in URBAN would increase attainment between .29 and .42 (1990 to 2004) percentage points while for SAL the increase would range from .41 to .52 (1970 to 1994) percentage points. The explanatory power of the model is also large over the period ranging from .52 to .69 . 
Table 30

Regression Results: Dimensions of globalization, attainment in higher education (ATTAINP) and control variables

Table 30 Regression Results: Dimensions of Globalization, attainment in higher educlation (ATTAINP) and

\begin{tabular}{|c|c|c|c|c|c|c|c|c|}
\hline Variable & $\begin{array}{l}1970- \\
74\end{array}$ & $\begin{array}{l}1975- \\
79\end{array}$ & $\begin{array}{l}1980- \\
84\end{array}$ & $\begin{array}{l}1985- \\
89\end{array}$ & $\begin{array}{l}1990- \\
94\end{array}$ & $\begin{array}{l}1995- \\
99\end{array}$ & $\begin{array}{l}2000- \\
04\end{array}$ & $\begin{array}{l}2005- \\
09\end{array}$ \\
\hline ECONG & - & .17 & .07 & -.10 & -.18 & -.09 & -.17 & -.01 \\
\hline POLG & - & -.09 & .07 & -.12 & -08 & -.19 & -.06 & -.07 \\
\hline TECG & - & -.04 & -.08 & -.03 & .05 & .06 & .05 & .16 \\
\hline CULG & - & -.14 & -.10 & -.04 & -.01 & .11 & .18 & .04 \\
\hline GDPPCAP & - & .49 & -.10 & .24 & .25 & $.32 *$ & $.30 *$ & $.35 *$ \\
\hline URBAN & - & .26 & .35 & .18 & $.42 *$ & $.38^{*}$ & $.29 *$ & .24 \\
\hline CAPSTOCK & - & -.13 & .00 & -.21 & -.17 & -.07 & .03 & .04 \\
\hline DEMOCRACY & - & -.14 & .12 & .22 & .03 & .15 & $.20 *$ & .13 \\
\hline SAL & - & $.41 *$ & $.52 *$ & $.49 *$ & $.44^{*}$ & .17 & .15 & .12 \\
\hline TOTEDEXP & - & .02 & -.02 & -.11 & -.05 & -.11 & -.11 & -.15 \\
\hline$R^{2}$ & - & $.69 * *$ & $.52 * *$ & $.62 * *$ & $.69 * *$ & $.64 * *$ & $.61 * *$ & $.60 * *$ \\
\hline$N$ & - & 43 & 46 & 45 & 49 & 66 & 76 & 70 \\
\hline
\end{tabular}

Notes: ${ }^{*} p<.05 .{ }^{* *} p<.01$. Standardized coefficients. Dependent variable: ATTAINP - Percentage of population 15 years and over attaining education at the tertiary level. Globalization dimensions: ECONG economic globalization, POLG - political globalization, TECG - technological globalization, CULG cultural globalization. Control variables: GDPPCAP - GDP per capita, URBAN - urban population, CAPSTOCK - capital intensity, DEMOCRACY - popularly based government, SAL - population attaining secondary (lagged), TOTEDEXP - total education expenditure.

For the attainment model ATTAINY, the results were similar to that of the ATTAINP model indicating that the variables are capturing similar concepts with the same three dimensions showing significance. Like the ATTAINY model, the main driver of globalization appears to be technology (Table 31). For seven of the eight periods, this variable is significant and has a positive sign. For a one point increase in the index of technological globalization, attainment in higher education would increase between .28 and .53 percentage points (1970 to 2004). Political globalization was significant between 1970 and 1989 and is also positive indicating that the more politically globalized a country was the greater the attainment in higher education. A one point increase in the index of political globalization would increase attainment in higher education between .25 and .30 percentage points. 
Table 31

Regression Results: Dimensions of globalization and attainment in higher education (ATTAINY)

\begin{tabular}{|l|l|l|l|l|l|l|l|l|}
\hline Variable & $1970-$ & $1975-$ & $\begin{array}{l}1980- \\
84\end{array}$ & $\begin{array}{l}1985- \\
89\end{array}$ & $\begin{array}{l}1990- \\
94\end{array}$ & $\begin{array}{l}1995- \\
99\end{array}$ & $\begin{array}{l}2000- \\
04\end{array}$ & $\begin{array}{l}2005- \\
09\end{array}$ \\
\hline ECONG & .01 & .00 & -.07 & -.08 & -.14 & -.08 & -.03 & .07 \\
\hline POLG & $.30^{* *}$ & $.29 * *$ & $.29 * *$ & $.25^{*}$ & .18 & .12 & .12 & .11 \\
\hline TECG & $.29 *$ & $32^{* *}$ & $.40^{* *}$ & $.43^{* *}$ & $.53^{* *}$ & $.45^{* *}$ & $.28^{*}$ & .21 \\
\hline CULG & $.24 * *$ & $.26^{* *}$ & .17 & .17 & .18 & .29 & $.43 * *$ & $.44 * *$ \\
\hline$R^{2}$ & $.46^{* *}$ & $.50^{* *}$ & $.46^{* *}$ & $.46^{* *}$ & $.45^{* *}$ & $.50 * *$ & $.50^{* *}$ & $.54 * *$ \\
\hline$N$ & 100 & 103 & 105 & 105 & 107 & 108 & 107 & 108 \\
\hline
\end{tabular}

Notes: ${ }^{*} p<.05 .{ }^{* *} p<.01$. Standardized coefficients. Dependent variable: ATTAINY- average years of tertiary schooling of the population. Globalization dimensions: ECONG - economic globalization, POLG political globalization, TECG - technological globalization, CULG - cultural globalization.

Cultural globalization was significant for the first two and last two years of the

period. The sign is also positive, indicating that the more culturally globalized a country was the greater the attainment in higher education. A one point increase in the index of cultural globalization would increase attainment in higher education between .24 and .44 percentage points. The explanatory power of the ATTAINP model is also large ranging from $.45(1990-1994)$ to $.54(2005-2009)$.

When the control variables are introduced (Table 32) none of the globalization dimensions were significant confirming previous estimates which used the overall index of globalization. However, three of the control variables namely GDP per capita (GDPPCAP), urban population (URBAN) and secondary attainment lagged (SAL) were relatively significant. GDPPCAP was positive indicating that improvements in the economy positively influenced attainment in higher education. A one point increase in GDPPCAP would increase attainment by .35 to .44 (1995-2009) percentage points. The greater the urban population (URBAN) and the greater the attainment at the secondary level (SAL), the higher will be the attainment in higher education. A one point increase in URBAN would increase attainment between .30 and .44 (1980-1984 and 1990 to 2009) 
percentage points while for SAL the increase would range from .40 to .54 (1975 to 1994)

percentage points. The explanatory power of the model is also large over the period

ranging from .56 to .71 .

Table 32

Regression Results: Dimensions of globalization, attainment in higher education (ATTAINY) and control variables

Table 32 Regression Results: Dimensions of Globalization, attainment in higher education (ATTAINY) and

\begin{tabular}{|l|c|l|l|l|l|l|l|l|}
\hline Variable & $1970-$ & $1975-$ & $1980-$ & $1985-$ & $1990-$ & $1995-$ & $2000-$ & $2005-$ \\
& 74 & 79 & 84 & 89 & 94 & 99 & 04 & 09 \\
\hline ECONG & - & .08 & -.00 & -.14 & -.18 & -.08 & -.15 & .01 \\
\hline POLG & - & -.16 & -.01 & -.11 & -.09 & -.18 & -.05 & -.07 \\
\hline TECG & - & .01 & -.11 & -.02 & -.03 & .04 & .04 & .17 \\
\hline CULG & - & -.14 & -.08 & -.00 & .00 & .07 & .10 & -.07 \\
\hline GDPPCAP & - & .54 & .01 & .22 & .32 & $.36^{*}$ & $.35^{*}$ & $.44^{*}$ \\
\hline URBAN & - & .28 & $.40^{*}$ & .19 & $.44^{*}$ & $.42^{*}$ & $.35^{*}$ & $.30^{*}$ \\
\hline CAPSTOCK & - & -.14 & -.03 & -.22 & -.16 & -.03 & .03 & .05 \\
\hline DEMOCRACY & - & -.15 & .09 & .19 & .04 & .12 & $.20^{*}$ & .13 \\
\hline SAL & - & $.42^{*}$ & $.54^{*}$ & $.51^{*}$ & $.40^{*}$ & .14 & .14 & .09 \\
\hline TOTEDEXP & - & .04 & -.03 & -.11 & -.05 & -.06 & -.11 & -.15 \\
\hline$R^{2}$ & - & $.71^{* *}$ & $.56^{* *}$ & $.64^{* *}$ & $.69^{* *}$ & $.65^{* *}$ & $.64^{* *}$ & $.66^{* *}$ \\
\hline$N$ & - & 43 & 46 & 45 & 49 & 66 & 76 & 70 \\
\hline
\end{tabular}

Notes: ${ }^{*} p<.05 .{ }^{* *} p<.01$. Standardized coefficients. Dependent variable: ATTAINY -average years of tertiary schooling of the population. Globalization dimensions: ECONG - economic globalization, POLG political globalization, TECG - technological globalization, CULG - cultural globalization. Control variables: GDPPCAP - GDP per capita, URBAN - urban population, CAPSTOCK - capital intensity, DEMOCRACY - popularly based government, SAL - population attaining secondary (lagged), TOTEDEXP - total education expenditure.

Participation. The results for the participation model (PARTIC) show that technological globalization is the main driver of globalization indicating that countries that have a higher level of technological globalization experience higher participation in higher education (Table 33). The coefficient is positive and a one point increase in technological globalization would increase participation by .33 to .48 percentage points (1975-2009). Political and cultural globalization indices are also significant and positive with a one point increase in the index of political globalization increasing participation by between .18 and .42 percentage points (1975 to 2004). A one point increase in cultural 
globalization would increase participation by between .26 and .41 percentage points (1975-79, 1985-2009).The explanatory power of the model is also large ranging from .53 to .73 over the period.

Table 33

Regression Results: Dimensions of globalization and participation in higher education (PARTIC)

\begin{tabular}{|l|l|l|l|l|l|l|l|l|}
\hline Variable & $1970-$ & $1975-$ & $1980-$ & $1985-$ & $1990-$ & $1995-$ & $2000-$ & $2005-$ \\
& 74 & 79 & 84 & 89 & 94 & 99 & 04 & 09 \\
\hline ECONG & -.11 & -.12 & -.10 & -.10 & -.14 & -.12 & .03 & .01 \\
\hline POLG & .49 & $.39 * *$ & $.42 * *$ & $.35 * *$ & $.18^{* *}$ & $.24 * *$ & $.24 * *$ & .16 \\
\hline TECG & .29 & $.37 * *$ & $.34 * *$ & $.33^{* *}$ & $.48^{* *}$ & $.45^{* *}$ & $.40^{* *}$ & $.39 * *$ \\
\hline CULG & .23 & $.26 * *$ & .19 & $.29 * *$ & $.41^{* *}$ & $.36^{* *}$ & $.31 * *$ & $.38^{* *}$ \\
\hline$R^{2}$ & $.57 * *$ & $.60^{* *}$ & $.53^{* *}$ & $.59 * *$ & $.69 * *$ & $.73 * *$ & $.71 * *$ & $.65^{* *}$ \\
\hline$N$ & 84 & 93 & 95 & 103 & 101 & 103 & 102 & 99 \\
\hline
\end{tabular}

Notes: ${ }^{*} p<.05 .{ }^{* *} p<.01$. Standardized coefficients. Dependent variable: PARTIC - gross enrollment ratio in higher education. Globalization dimensions: ECONG - economic globalization, POLG - political globalization, TECG - technological globalization, CULG - cultural globalization.

Table 34 shows the results of the regression with the control variables included.

None of the globalization dimensions were significant. This is in keeping with earlier findings of the overall index. See Table 22. However, URBAN, DEMOCRACY and SGERL control variables were relatively significant.

The greater the urban population (URBAN), the higher will be the equity in higher education. A one point increase in URBAN would increase attainment between .29 and .59 (1975 to 1984, 2000-2004) percentage points. While for DEMOCRACY, the coefficients are positive with a one point increase in DEMOCRACY increasing participation between .16 (2000-2004) and -.48 (1995-1999) percentage points. Secondary enrolment (SGERL) is significant for three periods (1990-1994, 2000-2004 and 2005 -2009). The coefficient is also positive with a one point increase in SGERL increase participation in higher education between .31 and .40 percentage points. The explanatory power of the model is also large over the period ranging from .68 to .85 . 
Table 34

Regression Results: Dimensions of globalization, participation in higher education (PARTIC) and control variables

Table 34 Regression Results: Dimensions of Globalization, participation in higher Education (PARTIC) and

\begin{tabular}{|l|c|l|l|l|l|l|l|l|}
\hline Variable & $1970-$ & $1975-$ & $\begin{array}{l}1980- \\
74\end{array}$ & $\begin{array}{l}1985- \\
89\end{array}$ & $\begin{array}{l}1990- \\
94\end{array}$ & $\begin{array}{l}1995- \\
99\end{array}$ & $\begin{array}{l}2000- \\
04\end{array}$ & $\begin{array}{l}2005- \\
09\end{array}$ \\
\hline ECONG & - & -.03 & -.02 & -.29 & -.20 & -.03 & -.03 & -.01 \\
\hline POLG & - & .19 & .08 & -.04 & .18 & .14 & .12 & .12 \\
\hline TECG & - & .03 & -.15 & .11 & .15 & -.28 & .03 & .16 \\
\hline CULG & - & .16 & .22 & .36 & .14 & -.20 & .09 & .09 \\
\hline GDPPCAP & - & .27 & .15 & .15 & .17 & -.39 & .12 & .17 \\
\hline URBAN & - & $.30 *$ & $.59 *$ & .14 & .12 & .21 & $.29^{*}$ & .16 \\
\hline CAPSTOCK & - & .11 & .11 & -.13 & -.11 & .05 & .10 & .06 \\
\hline DEMOCRACY & - & .03 & .04 & -.00 & -.00 & $.48^{*}$ & $.16^{*}$ & .07 \\
\hline SGERL & - & .12 & .08 & .44 & $.40^{*}$ & .61 & $.31^{*}$ & $.31 *$ \\
\hline TOTEDEXP & - & -.07 & -.06 & -.14 & .03 & .18 & .03 & -.03 \\
\hline$R^{2}$ & - & $.85 * *$ & $.73 * *$ & $.68^{* *}$ & $.74 * *$ & $.81 * *$ & $.81^{* *}$ & $.80^{* *}$ \\
\hline$N$ & - & 41 & 44 & 45 & 48 & 61 & 73 & 74 \\
\hline
\end{tabular}

Notes: ${ }^{*} p<.05 .{ }^{* *} p<.01$. Standardized coefficients. Dependent variable: PARTIC - gross enrollment ratio in higher education,. Globalization dimensions: ECONG - economic globalization, POLG - political globalization, TECG - technological globalization, CULG - cultural globalization. Control variables: GDPPCAP -GDP per capita, URBAN - urban population, CAPSTOCK - capital intensity, DEMOCRACY - popularly based government, SGERL - gross enrollment ratio secondary (lagged), TOTEDEXP - total education expenditure.

Gender Equity. The results for the gender equity models indicate that for the GENEQUC specification, only two dimensions, the technological and political; show any degree of significance (Table 35). The significance is however limited. For technological globalization only two periods of significance were recorded (1995-1999 and 2005 2009) while for political globalization there was only one period where significance was recorded (2000-2004). The coefficients for technological globalization are positive indicating that as countries become more and more technologically globalized, equity in higher education improves. The opposite is true for political globalization where the coefficient has a negative sign indicating that as a country becomes more globalized the lower the gender equity in higher education. 
Table 35

Regression Results: Dimensions of globalization and gender equity in higher education (GENEQUC)

\begin{tabular}{|c|c|c|c|c|c|c|c|c|}
\hline Variable & $\begin{array}{l}1970- \\
74\end{array}$ & $\begin{array}{l}1975- \\
79\end{array}$ & $\begin{array}{l}1980- \\
84\end{array}$ & $\begin{array}{l}1985- \\
89\end{array}$ & $\begin{array}{l}1990- \\
94\end{array}$ & $\begin{array}{l}1995- \\
99\end{array}$ & $\begin{array}{l}2000- \\
04\end{array}$ & $\begin{array}{l}2005- \\
09\end{array}$ \\
\hline ECONG & .10 & .08 & -.00 & .25 & .34 & .02 & -.01 & -.04 \\
\hline POLG & -.02 & .04 & -.07 & .02 & -.13 & -.21 & $-.26^{*}$ & -.13 \\
\hline TECG & .20 & .26 & .31 & .22 & .12 & $.44^{*}$ & .31 & $.39 *$ \\
\hline CULG & .03 & -.14 & -.14 & -.23 & -.07 & -.01 & -.05 & -.08 \\
\hline$R^{2}$ & .08 & .08 & .06 & $.11 *$ & $.13 * *$ & $.16 * *$ & $.09 *$ & $.09 *$ \\
\hline$N$ & 99 & 101 & 103 & 105 & 107 & 108 & 107 & 107 \\
\hline
\end{tabular}

Notes: $* p<.05 .{ }^{* *} p<.01$. Standardized coefficients. Dependent variable: GENEQUC - ratio of females to males completing higher education, Globalization dimensions: ECONG - economic globalization, POLG political globalization, TECG - technological globalization, CULG - cultural globalization.

For a one point increase in the index of technological globalization, gender equity would increase by .39 to .44 percentage points while the index of political globalization would decrease by .26 percentage points. The explanatory power of the model is medium with the $R^{2}$ s ranging from .09 to .16 .

When the control variables are included in the model, political globalization remained significant for two periods (1990 -94 and 2000-04) with a one point increase in the sub-index decreasing equity between .35 and .75 percentage points (Table 36 ). Technological globalization, however was no longer significant. Additionally, economic globalization was significant and positive an indicator that the economic factor was an influential in the 1990-1994 period. A one point increase in economic globalization would increase equity by .86 percentage points.

Three of the control variables namely GDPPCAP, URBAN, and DEMOCRACY were relatively significant. GDPPCAP was negative indicating that improvements in the economy were associated with decreased gender equity in higher education. A one point increase in GDPPCAP would decrease equity by .71 (1985-1989) percentage points. The 
greater the urban population (URBAN), the higher will be the equity in higher education.

A one point increase in URBAN would increase attainment between .39 and .59 (1995 to 2009) percentage points. While for DEMOCRACY, the coefficients are mixed with one period showing a positive impact while the other shows a negative impact, .45 (1985$1989)$ and -.48 (1990-1994) percentage points respectively. The explanatory power of the model is also large over the period ranging from .25 to .49 .

Table 36

Regression Results: Dimensions of globalization, gender equity in higher education (GENEQUC) and control variables

Table 36 Regression Results: Dimensions of Globalization, gender equity in Higher Education (GENEQUC) and

\begin{tabular}{|l|c|l|l|l|l|l|l|l|}
\hline Variable & $1970-$ & $1975-$ & $1980-$ & $1985-$ & $1990-$ & $1995-$ & $2000-$ & $2005-$ \\
& 74 & 79 & 84 & 89 & 94 & 99 & 04 & 09 \\
\hline ECONG & - & .05 & .22 & .25 & $.86^{*}$ & .33 & -.09 & -.02 \\
\hline POLG & - & .28 & .21 & -.19 & $-.75^{*}$ & -.18 & $-.35^{*}$ & -.25 \\
\hline TECG & - & .24 & -.14 & -.14 & -.01 & .14 & .08 & -.11 \\
\hline CULG & - & -.10 & .02 & .30 & .14 & -.11 & .15 & .15 \\
\hline GDPPCAP & - & -.49 & -.67 & $-.71^{*}$ & .18 & -.14 & -.22 & -.30 \\
\hline URBAN & - & .21 & .37 & .28 & .04 & $.39^{*}$ & $.43^{*}$ & $.59^{*}$ \\
\hline CAPSTOCK & - & .17 & .15 & -.13 & -.21 & .13 & .22 & .04 \\
\hline DEMOCRACY & - & .17 & .03 & $.45^{*}$ & $-.48^{*}$ & .08 & .22 & .27 \\
\hline SAL & - & .27 & .36 & .26 & -.05 & -.08 & -.14 & .02 \\
\hline TOTEDEXP & - & -.15 & -.27 & -.22 & -.26 & -.09 & .19 & .14 \\
\hline$R^{2}$ & - & .34 & .35 & $.49^{* *}$ & $.41^{*}$ & $.35^{* *}$ & $.25^{*}$ & $.30^{*}$ \\
\hline$N$ & - & 43 & 46 & 45 & 49 & 66 & 76 & 69 \\
\hline
\end{tabular}

Notes: ${ }^{*} p<.05 .{ }^{* *} p<.01$. Standardized coefficients. Dependent variable: GENEQUC - ratio of females to males completing higher education. Globalization dimensions: ECONG - economic globalization, POLG political globalization, TECG - technological globalization, CULG - cultural globalization. Control variables: GDPPCAP -GDP per capita, URBAN - urban population, CAPSTOCK - capital intensity, DEMOCRACY - popularly based government, SAL - population attaining secondary (lagged), TOTEDEXP - total education expenditure.

The results for the other specification of gender equity (GENEQUGER), is shown in Table 37 with technological globalization emerging as the only significant globalization dimension. A one point increase in the index of technological globalization would increase gender equity in higher education between .45 and .74 percentage points 
(1980 to 1999). The explanatory power of the model was medium to large with $R^{2}$

ranging from .14 to .24 .

Table 37

Regression Results: Dimensions of globalization and gender equity in higher education (GENEQUGER)

Table 37 Regression Results: Dimensions of Globalization and Gender Equity in Higher Education

\begin{tabular}{|l|l|l|l|l|l|l|l|l|}
\hline Variable & $1970-$ & $1975-$ & $1980-$ & $1985-$ & $1990-$ & $1995-$ & $2000-$ & $2005-$ \\
& 74 & 79 & 84 & 89 & 94 & 99 & 04 & 09 \\
\hline ECONG & .11 & -.15 & -.21 & -.29 & -.20 & -.23 & .11 & .18 \\
\hline POLG & .13 & .02 & .03 & -.19 & .011 & -.15 & .09 & -.02 \\
\hline TECG & .20 & .35 & $.45^{*}$ & $.74^{* *}$ & $.68^{* *}$ & $.66^{* *}$ & .30 & .21 \\
\hline CULG & -.03 & -.16 & -.11 & -.01 & -.21 & .01 & -.08 & .06 \\
\hline$R^{2}$ & .12 & .06 & .09 & $.24 * *$ & $.19^{* *}$ & $.20^{* *}$ & $.14^{*}$ & $.16^{* *}$ \\
\hline$N$ & 68 & 76 & 72 & 72 & 75 & 83 & 92 & 89 \\
\hline
\end{tabular}

Notes: ${ }^{*} p<.05 .{ }^{* *} p<.01$. Standardized coefficients. Dependent variable: GENEQUGER - ratio of females to males enrolled in higher education. Globalization dimensions: ECONG - economic globalization, POLG - political globalization, TECG - technological globalization, CULG - cultural globalization.

Introducing the control variables resulted in none of the globalization dimensions

being significant (Table 38). With the exception of SGERL (lagged secondary gross

enrolment ratio), none of the control variables were significant. SGERL was significant

and positive for three periods (1980-84, 1990-94 and 1995-99). A one point increase in

the secondary enrolment would increase equity by between .61 to1.04 percentage points.

The explanatory power of the model is large with $R^{2}$ ranging from .22 to .58 over the period. 
Table 38

Regression Results: Dimensions of globalization, gender equity in higher education (GENEQUGER) and control variables

Table 38 Regression Results: Dimensions of Globalization, gender equity in higher education (GENEQUGER)

\begin{tabular}{|l|c|l|l|l|l|l|l|l|}
\hline Variable & $1970-$ & $1975-$ & $1980-$ & $1985-$ & $1990-$ & $1995-$ & $2000-$ & $2005-$ \\
& 74 & 79 & 84 & 89 & 94 & 99 & 04 & 09 \\
\hline ECONG & - & .04 & -.36 & -.41 & .11 & -.03 & .18 & .05 \\
\hline POLG & - & -.17 & -.36 & -.43 & -.10 & .14 & .06 & -.09 \\
\hline TECG & - & .57 & .28 & -.09 & .02 & -.28 & -.04 & .05 \\
\hline CULG & - & -.48 & .05 & .31 & -.25 & -.20 & .51 & .39 \\
\hline GDPPCAP & - & .79 & -.29 & -.32 & .01 & -.39 & -.38 & -.07 \\
\hline URBAN & - & -.15 & .38 & .42 & -.40 & .21 & -.01 & -.08 \\
\hline CAPSTOCK & - & -.17 & -.29 & .13 & .01 & .05 & -.05 & .07 \\
\hline DEMOCRACY & - & -.51 & -.47 & .16 & -.01 & .48 & .20 & .14 \\
\hline SGERL & - & -.00 & $1.04^{*}$ & .80 & $1.03^{*}$ & $.61 *$ & .03 & .10 \\
\hline TOTEDEXP & - & -.37 & -.03 & -.18 & .08 & .18 & -.10 & -.08 \\
\hline$R^{2}$ & - & .39 & .51 & $.58^{*}$ & .53 & $.38^{*}$ & $.34 *$ & .22 \\
\hline$N$ & - & 33 & 30 & 29 & 31 & 49 & 60 & 64 \\
\hline
\end{tabular}

Notes: $* p<.05 . * * p<.01$. Standardized coefficients. Dependent variable: GENEQUGER - Ratio of females to males completing higher education. Globalization dimensions: ECONG - economic globalization, POLG - political globalization, TECG - technological globalization, CULG - cultural globalization. Control variables: GDPPCAP -GDP per capita, URBAN - urban population, CAPSTOCK capital intensity, DEMOCRACY - popularly based government, SGERL -gross enrollment ratio secondary (lagged), TOTEDEXP - total education expenditure.

\section{Conclusion}

The findings of the investigation of the relationship between globalization and the public provision of higher education in selected countries appear to be mixed. The research did not find a significant relationship between the globalization variables and the education variables after controlling for several demographic, economic and political factors such as GDP per capita, democracy, population and capital stock. Globalization as measured by the KOF index was found to have no consistently significant effect on spending on higher education and on various education outcome indicators (attainment, gender equity and participation). The results presented in this chapter will be examined further in Chapter 5. The implications and limitations of the study as well as possible new areas of research deriving from this research will also be presented. 


\section{CHAPTER 5}

\section{CONCLUSION}

This research study examined the relationship between globalization and its dimensions (economic, political, technological and cultural) and the public provision of higher education in selected countries. Globalization was measured using the KOF index. The provision of higher education was examined using spending and educational outcome models. Educational outcome was measured by attainment, participation and gender equity. A total of 139 countries were included in the study and the data period covered from 1970 to 2009 . This chapter is organized as follows. The main findings and their implications are analyzed. The limitations of the study and the directions for future research are then discussed.

\section{Discussion of Main Findings and Implications}

The outline of this section is as follows: each of the three research questions will be presented. The results will then be evaluated and interpreted within the context of the two major perspectives of economic openness theory, the efficiency hypothesis and compensation hypothesis, as well as empirical studies cited in the literature review (Chapter 2). Table 39 summarizes the major findings of this study. It shows the effects of globalization and its dimensions on higher education spending and education outcomes. In summary, the statistical study did not find a significant relationship between globalization as measured by the KOF index and the higher education variables after controlling for economic, political and demographic factors. 
Table 39

Summary of Results

\begin{tabular}{|c|c|c|c|c|c|}
\hline Variables & KOF & ECONG & POLG & TECG & CULG \\
\hline SPENDGDPCAP & $\begin{array}{l}\text { Positive, } \\
\text { non- } \\
\text { significant }\end{array}$ & $\begin{array}{l}\text { Negative, } \\
\text { non- } \\
\text { significant, } \\
\text { least } \\
\text { important }\end{array}$ & $\begin{array}{l}\text { Negative, } \\
\text { significant, } \\
\text { most } \\
\text { important }\end{array}$ & $\begin{array}{l}\text { Negative, } \\
\text { non- } \\
\text { significant }\end{array}$ & $\begin{array}{l}\text { Positive, } \\
\text { non- } \\
\text { significant }\end{array}$ \\
\hline SPENDTOT & $\begin{array}{l}\text { Negative, } \\
\text { non- } \\
\text { significant }\end{array}$ & $\begin{array}{l}\text { Positive, } \\
\text { non- } \\
\text { significant, } \\
\text { most } \\
\text { important }\end{array}$ & $\begin{array}{l}\text { Positive, } \\
\text { non- } \\
\text { significant }\end{array}$ & $\begin{array}{l}\text { Positive, } \\
\text { non- } \\
\text { significant }\end{array}$ & $\begin{array}{l}\text { Negative, } \\
\text { non- } \\
\text { significant, } \\
\text { least } \\
\text { important }\end{array}$ \\
\hline ATTAINY & $\begin{array}{l}\text { Negative, } \\
\text { non- } \\
\text { significant }\end{array}$ & $\begin{array}{l}\text { Negative, } \\
\text { non- } \\
\text { significant, } \\
\text { least } \\
\text { important }\end{array}$ & $\begin{array}{l}\text { Positive, } \\
\text { non- } \\
\text { significant }\end{array}$ & $\begin{array}{l}\text { Positive, } \\
\text { non- } \\
\text { significant } \\
\text { most } \\
\text { important }\end{array}$ & $\begin{array}{l}\text { Positive, } \\
\text { non- } \\
\text { significant }\end{array}$ \\
\hline ATTAINP & $\begin{array}{l}\text { Negative, } \\
\text { non- } \\
\text { significant }\end{array}$ & $\begin{array}{l}\text { Negative, } \\
\text { non- } \\
\text { significant, } \\
\text { least } \\
\text { important }\end{array}$ & $\begin{array}{l}\text { Positive, } \\
\text { non- } \\
\text { significant }\end{array}$ & $\begin{array}{l}\text { Positive, } \\
\text { non- } \\
\text { significant, } \\
\text { most } \\
\text { important }\end{array}$ & $\begin{array}{l}\text { Positive, } \\
\text { non- } \\
\text { significant }\end{array}$ \\
\hline GENEQUC & $\begin{array}{l}\text { Positive, } \\
\text { non- } \\
\text { significant }\end{array}$ & $\begin{array}{l}\text { Positive, } \\
\text { non- } \\
\text { significant, } \\
\text { most } \\
\text { important }\end{array}$ & $\begin{array}{l}\text { Negative, } \\
\text { non- } \\
\text { significant }\end{array}$ & $\begin{array}{l}\text { Positive, } \\
\text { non- } \\
\text { significant }\end{array}$ & $\begin{array}{l}\text { Negative, } \\
\text { non- } \\
\text { significant, } \\
\text { least } \\
\text { important }\end{array}$ \\
\hline GENEQUGER & $\begin{array}{l}\text { Negative, } \\
\text { non- } \\
\text { significant }\end{array}$ & $\begin{array}{l}\text { Negative, } \\
\text { non- } \\
\text { significant }\end{array}$ & $\begin{array}{l}\text { Positive, } \\
\text { non- } \\
\text { significant, } \\
\text { least } \\
\text { important }\end{array}$ & $\begin{array}{l}\text { Positive, } \\
\text { non- } \\
\text { significant, } \\
\text { most } \\
\text { important }\end{array}$ & $\begin{array}{l}\text { Negative, } \\
\text { non- } \\
\text { significant }\end{array}$ \\
\hline PARTIC & $\begin{array}{l}\text { Positive, } \\
\text { non- } \\
\text { significant }\end{array}$ & $\begin{array}{l}\text { Positive, } \\
\text { non- } \\
\text { significant, } \\
\text { least } \\
\text { important }\end{array}$ & $\begin{array}{l}\text { Positive, } \\
\text { mixed }\end{array}$ & $\begin{array}{l}\text { Positive, } \\
\text { mixed, most } \\
\text { important }\end{array}$ & $\begin{array}{l}\text { Positive, } \\
\text { non- } \\
\text { significant }\end{array}$ \\
\hline
\end{tabular}

\section{Relationship between globalization and public spending on higher education}

I hypothesized a positive relation between globalization as measured by the KOF index and spending on higher education. Two variables of higher education spending were used, SPENDGDPPCAP and SPENDTOT, which measured spending per student and government respectively. The result did not match our a priori expectations. The 
result showed that the globalization coefficient was not significant for the SPENDTOT variable and was significant and negative for the last three periods for the SPENDGDPPCAP variable. The results were also not significant when alternative globalization measures were used.

This finding is not surprising and is in keeping with the findings of a number of empirical studies cited in the literature review which show mixed results for the relationship between globalization however measured and social spending both in terms of sign and level of significance. Chen's (2007) study of globalization and democratization on government provision of education in East Asia, for example, found that there was no robust relationship between the globalization variables and the educational variables. More specifically, the study found that globalization as measured by trade integration and capital account openness had no significant impact on spending on higher education. These findings also proved to be quite robust to alternative specifications of the globalization variable. Other non-significant relationships have been found in studies by Kaufman and Segura-Ubiergo (2001) and Avelino, Brown and Hunter (2005).

Kaufman and Segura-Ubiergo (2001) in a study of globalization and social spending in Latin America found that in a social spending model that aggregated health and education spending, globalization as measured by trade was not significant. For the capital openness measure of globalization, the results were positive and significant but less stable for alternative specifications of the model. Avelino, Brown and Hunter's (2005) study of social spending and globalization in Latin America, found that aggregate 
education expenditure had a strong negative and significant correlation with globalization measured as trade openness.

While none of the empirical studies highlighted used the KOF globalization index nor with the exception of Chen(2007) focused on higher education, the results of my study seem to add evidence to the current literature which sees mixed results on the impact of globalization on spending on education. The results do not lend support to either theory of economic openness, the efficiency hypothesis nor the compensation hypothesis. Arguably, these perspectives may cancel each other out.

\section{Relationship between globalization and selected higher education outcomes}

I hypothesized a positive relation between globalization as measured by the KOF index and higher education outcomes. Three measures of higher education outcomes were used, attainment, participation and gender equity. The result did not match our a priori expectations. The result showed that for the educational outcome models, globalization was not significant. The finding was supported by the alternative measures of globalization.

The results are similar to the findings by Chen (2007) who found that the globalization variables did not have a significant impact on higher education outcomes. As discussed with the spending model, it is possible that the efficiency and compensation hypothesis cancel each other out. However, data issues may also play a role (Chen, 2007). The attainment and gender equity data (ATTAINY and GENEQUC) are only available every five years. Gross enrolment is used for the participation and GENEQUGER models. However, this variable may not adequately estimate enrolment. Net enrolment is a better indicator. 


\section{Dimensions of globalization}

Most studies of globalization and social spending adopt an economic measure of globalization such as trade, capital account openness and foreign direct investment (Chen, 2007 \& Segura-Ubiergo, 2001). It is however been increasingly recognized that globalization is not just an economic construct but is multidimensional in scope hence the development of more comprehensive measures of globalization such as the KOF index which includes the political, social as well as the economic aspect of globalization (Dreher, Gaston \& Martens, 2008 ). This study identified four dimensions of globalization (economic, political, cultural and technological). I hypothesized that economic globalization as measured by the KOF globalization sub-index would be the major dimension contributing to globalization in higher education.

The substantive finding was that economic globalization was not the major dimension of globalization affecting higher education spending and outcomes. This variable was significant but negative for one period (1970-74) for the SPENDTOT model and significant but positive for one period (1990-94) for the GENEQUC model. I have also found that the effect of cultural globalization on the public provision of higher education is not very significant. This may indicate that cultural globalization is not a very important aspect of higher education, but it is also possible that the effect varies between different types of cultural globalization, or between different countries. Technological globalization also is only significant for two periods in one model, the SPENDTOT model.

Two factors that may be considered to explain why the globalization sub-indices do not appear to have a significant impact on higher education spending and outcomes 
are the level of aggregation of the sub-indices and the high degree of colinearity among them. The KOF economic globalization sub-index for example comprises two main components, actual flows and restrictions. Each of these components comprises four to five measures. See Appendix B. The level of aggregation of the economic sub-index may thus affect the results. Further disaggregating this sub-index may capture different effects of economic globalization on higher education. Also this study included all sub-indices together in the same specification. In light of the possible colinearity problem that may arise because of the relationships between the globalization sub-indices, testing of the components separately should be done. This may yield different results.

The main driver of spending in higher education appears to be political globalization. Political globalization has a negative effect on higher education spending as measured by spending per student per capita. This indicates that countries with more embassies, memberships in international organizations and international treaties and which also participate in the U.N. Security Council missions have lower spending on higher education. This result does not match our expectations. However, it may be an indication that the policies of the international community that favor reducing government financial support for education are being filtered down to the policy level for individual countries. Thus the efficiency hypothesis where the state is viewed as encouraging globalization would seem to be supported.

However, tests of the robustness of this result would need to be carried out to determine whether the results would change. Theories of political globalization are directly related to the role of state in policy and thus the nature of the state itself may 
impact the results. Possible tests include splitting the data by countries based on their level of development and colonial history for example.

\section{Contributions to literature}

This study contributes to the literature on globalization and higher education in three important ways: a) it fills an important gap in the literature on several levels; b) the results help us better understand the effects of globalization on the public provision of higher education; and c) the use of an alternative research design.

This research fills an important gap in the literature in terms of providing a quantitative as opposed to a qualitative assessment of the relationship between globalization and higher education, by focusing on higher education as opposed to education in general and by including as many countries for which substantial data was available. Empirical research on globalization and education is limited. Research on globalization tends to focus mainly on social welfare and where studies have included higher education the emphasis has been on educational globalization. Much of the research is also limited to total education and is not specific to higher education. Further, the emphasis is on spending in education. This study, by including education outcomes in addition to education spending, recognizes the importance of these factors in assessing the relationship between globalization and education is one that is more than financial in nature.

Research also tends to focus on country groupings such as Latin America, Asia and political/economic groupings such as the OECD. This study by focusing on all countries of the world is an attempt to bridge that gap. The study includes 139 countries although data were not available for all countries for each variable. The inclusion of this 
many countries is important in that research on country groupings utilized differing methodologies, variables and time periods among others, making comparison of the findings difficult. By including as many countries for which data are available in the same study provides a standard for comparison of the findings.

The study also contributes to the literature by providing statistical assessments of the relationship between globalization and higher education. The major finding of this study is that globalization has a largely null effect on higher education after controlling for economic, political, and demographic influences. This finding is in keeping with the literature.

Lastly, this research study contributes to the literature by utilizing a research design that is powerful yet simple, a cross-sectional or across countries design. Most studies of globalization and its effects on social welfare would use a pooled times-series cross-sectional design (TSCS). This method has a number of limitations as presented in Chapter 3. The advantage of the cross section design is that it is useful when examining a large number of countries over a long period of time since the problem of missing data is not as problematic as with the TSCS design. With the TSCS design meaningful tests would have to be limited to developed countries and the periods after 1980s where data are more available.

The study contributes to the literature by testing the robustness of the findings using multiple indicators of globalization (KOF, TRADE, FDI) and higher education (spending, attainment, gender equity, participation). This addresses some of the limitations identified in the current literature with respect to the impact of the choice of globalization and higher education variable on the results. Additionally, the study also 
contributes to the literature by specifying a model that incorporates the factors specific to higher education and as such adopts variables such as the population in higher education age group and gross enrolment in higher education as controlling factors. Current literature usually adopts the variables identified in social spending models as the only controlling factors.

\section{Limitations}

The overarching limitation of this study was with respect to data in terms of availability, comparability and accuracy of the measures. In terms of availability since the study covered a relatively long period (1970 to 2009) and included a range of countries, data for some variables were not available or available sporadically. Variables with limited data included expenditure on higher education, government revenues and expenses. The availability of data was a reflection of several factors such as the development level of the country with developing countries like Zimbabwe having limited data as opposed to advanced countries like Canada and the United States. Another factor was the political, social and economic climate of the country. An example of this is the end of the Cold War in the 1990s which brought about a number of new countries in Europe and the combination of some. Also education attainment data was only available every 5 years.

Issues of comparability also arose particularly with the education data from the United Nations Education statistics where new methodology was adopted in the 1990s. This made comparability of earlier data difficult. An example of this is the data on education spending as a percentage of GDP. 
Another data limitation was the lack of accurate measures for some variables resulting in the use of variables that were a rough approximation of the measure. The total spending data for example only includes that of central government, data on expenditure of higher education only contains current expenditure and data on education participation would be better measured by net enrolment which was not available. Also the indicators for culture and technology may not accurately reflect cultural and technological globalization since they are in fact a sub-index of social globalization.

\section{Directions for future research}

There are a number of areas for future research that emerge from this study of the relationship between globalization and higher education. Firstly, further empirical studies can be conducted by changing the time period for example from five to ten year averages and for important periods of globalization such as before and after 1990. Additionally, studies of country groupings such as by geographic region or level of development can also be conducted to assess the robustness of the findings.

This study is quantitative in nature. The possible research outlet would be to conduct a comparative case study of the countries, included in the study. Countries could be categorized based geographic region such as Europe and Africa or based on economic/political groupings such as the OECD. Such a study could help reveal other impacts of globalization and higher education that cannot be captured by the statistical study such as changes in the school curriculum and the role of the state in school management. Any new findings would contribute to new theory building. The limitation of statistical study is that it cannot reveal causation. 
Since my study focuses only on higher education, it would be interesting to see whether the same results would apply to different levels of education namely primary and secondary. A possible study would be comparative assessment of all levels of education and for total education as well.

Another logical extension of the study would be to see what effects of globalization and higher education in small countries since it is sometimes argued that such countries tend to be more globalized since they are highly dependent on trade to sustain their economies

Another possible area for future research would be the political status of the country in terms of whether they were colonized or not. It is sometimes argued that countries that have historical ties to a colonial power have a higher level of globalization and tend to be followers in terms of policy which may have an impact on higher education. Any difference between countries that have been colonized and those that have not been would be interesting.

Globalization is not only a multidimensional construct but multidirectional as well. A study of its relationship with higher education at the local, national and regional level could be conducted. This will provide further details that may help explain the findings in this study.

In terms of the variables, research with additional measures of globalization can be conducted such as capital account restrictions that have been used in other globalization studies. Further studies using other globalization indices such as the CSGR and the MGI can be conducted to test the robustness of the findings of the study. In addition, studies of the sub-indices of the KOF globalization index for example economic 
globalization which is subdivided in two sub-indices, restrictions and flows can be conducted. Such a study will allow the researcher to examine what aspect of the economic globalization is significant if any.

Finally, another possible avenue for future research is health. Health has been identified as one of the major issues being affected by globalization. Examining health issues such as mortality and its relationship to the trends in education in the context of globalization provides a logical extension of this study.

\section{Conclusion}

What is clear from this study of the relationship between globalization and higher education is that, given the complex nature of globalization, its association with higher education needs to be addressed from multiple perspectives both in terms of theory and analytical approaches. Additionally, higher education is itself a complex variable that is becoming increasingly complex with the changes globalization. While this study is a step in that direction, building as it does on earlier work of Chen and others, further empirical research is needed to identify the relevant casual mechanisms underlying the influence of globalization on higher education. Such analysis of the relationship between globalization and higher education may contribute to better under of the process of globalization and its impact on higher education. 


\section{REFERENCES}

Al-Omari, A., \& Obeidat, O. (2006). University missions/goals in the context of globalization: Public and private institutions in the Middle East [Electronic version]. International Journal of Private Higher Education. 1, 20-36.

Altbach, P. G. (2004). Globalisation and the university: Myths and realities in an unequal world. Tertiary Education and Management, 10(1), 3-25.

Altbach, P. G. (2006). Higher education and the WTO: Globalization run amok. In P. G. Altbach, International higher education: Reflections on policy and practice ( $\mathrm{pp}$. 23-28). Chestnut Hill, MA: Center for International Higher Education.

Ansell, B. W. (2008). Traders, teachers, and tyrants: Democracy, globalization and public investment in education. International Organization, 62, 289-322.

Avelino, G., Brown, D. S. \& Hunter, W. (2005).The effects of capital mobility, trade openness, and democracy on social spending in Latin America, 1980-1999. American Journal of Political Science, 49(3), 625-641.

Banya, K. (2006). Globalization, social justice and education in Africa: Neoliberalism, knowledge capitalism in Sub-Sahara Africa. World Studies in Education, 7(1), 524.

Baskaran, T., \& Hessami, Z. (2010).Globalization, redistribution, and the composition of public education expenditures (Working Paper No. 2917). Munich, Germany: CESIFO.

Bastick, T. (2004). Commonwealth degrees from class to equivalence: Changing to grade point averages in the Caribbean, Journal of Studies in International Education, $8(1), 86-104$.

Beck, N., \& Katz, J.N. (1995). Nuisance vs substance: Specifying and estimating timeseries-cross-section models, Political Analysis, 6(1), 1-36.

Beck, N., \& Katz, J.N. (1996). What to do (and not to do) with time-series-cross-section data. American Political Science Review, 89(3), 634-647.

Beerkens, H. J. J. G. (2004). Global opportunities and institutional embeddedness: Higher education consortia in Europe and Southeast Asia. Enschede, Netherlands: CHEPS/UT.

Bisley, N. (2007). Rethinking globalization. Rethinking world politics. New York, NY: Palgrave Macmillan.

Bourne, C. (2004).Small states in the context of global change. Journal of Eastern Caribbean Studies, 29(3), 67-77. 
Brown, D. S., \& Hunter, W. (2004).Democracy and Human Capital Formation: Education Spending in Latin America, 1980 to 1997. Comparative Political Studies, 37, 842-864

Carnoy, M. (1999).Globalization and educational reform: what planners need to know. Paris, France: UNESCO.

Chen, J. (2007). Globalization, democratization and government education provision in East Asia. (Doctoral dissertation) Retrieved from Dissertations \& Theses: Full Text. (Publication No. AAT 3319600).

Clark, B. R. (1998). Creating entrepreneurial universities: Organizational pathways of transformation. Oxford, England: Published for the IAU Press by Pergamon Press.

Cohen, L., Manion, L., \& Morrison, K. (2003). Research methods in education. London: RoutledgeFalmer.

Daun, H. (2002). Educational restructuring in the context of globalization and national policy. New York, NY: RoutledgeFalmer.

Deem, R. (2001). Globalisation, new managerialism, academic capitalism and entrepreneurialism in universities: Is the local dimension still important? Comparative Education, 37(1), 7-20.

Dobson, I. R., \& Holtta, S. (2001). The internationalisation of university education: Australia and Finland compared. Tertiary Education and Management, 7(3), 243254.

Dreher, A., Gaston, N. \& Martens, P. (2008). Measuring globalization: Gauging its consequences. New York, NY: Springer.

Dreher, A., Sturm, J., \& Ursprung, H. W. (2008). The impact of globalization on the composition of government expenditures: Evidence from panel data. Public Choice, 134, 263-292.

Enders, J. (2004). Higher education, internationalization, and the nation-state: Recent developments and challenges to governance theory. Higher Education, 47, 361382.

Fitzsimons, P. (2000). Changing conceptions of globalization: Changing conceptions of education. Educational Theory, 50(4), 505-520.

Flint, N. (2000, December). Culture club: An investigation of organizational culture. Paper presented at the annual meeting of the Australian Association for Research in Education, Sydney, Australia. 
Forest, J. JF. (2004, September). Globalization and public policy trends in higher education: A comparative analysis. Paper presented at the Annual Meeting of the American Political Science Association, Chicago, IL.

Gibbons, M. (2002, September).Globalisation and the future of higher education Paper presented at the Conference "Globalization: What issues are at stake for universities?” Université Laval, Québec, Canada.

Green, A. (1997). Education, globalization, and the nation state. New York: St. Martin's Press.

Held, D., \& McGrew, A. (2002).Globalization/Anti-globalization. Cambridge, UK: Polity Press.

Held, D., McGrew, A., Goldblatt, D., \& Perraton, J. (1999).Global transformations: Politics, economics, culture. Cambridge, UK: Polity Press.

Hickling-Hudson, A. (2000). Globalization and universities in the Commonwealth Caribbean. In N. Stromquist \& K. Monkman, K. (eds.), Globalization and education: Integration and contestation across cultures (pp. 219-236). New York: Rowman and Littlefield Publishers Inc.

Hickling-Hudson, A. (2004). Towards Caribbean 'knowledge societies': Dismantling neo-colonial barriers in the age of globalization. Compare, 3(3), 293-300.

Hickling-Hudson, A. (2006). Cultural complexity, post-colonialism and educational change: Challenges for comparative educators. Review of Education, 52, 201-218.

Hopper, P. (2007).Understanding cultural globalization. Cambridge: Polity Press.

Howe, G. (2000). Higher education in the Caribbean: Past, present and future directions. Kingston: University Press of the West Indies.

Howe, G. D. (2005).Contending with change: Reviewing tertiary education in the English-speaking Caribbean. Caracas, Venezuela: International Institute for Higher Education in Latin America and the Caribbean (IESALC).

Huber, E., Mustillo, T., \& Stephens, J. (2004). "Determinants of Social Spending in Latin America." Paper delivered at the Meetings of the Society for the Advancement of Socio-Economics, Washington, DC, July 8-11.

Johnson, B., \& Christensen, L. (2004). Educational research: Quantitative, qualitative, and mixed approaches. Boston, MA: Pearson.

Jones, P. W. (1998). Globalisation and internationalism: Democratic prospects for world education. Comparative Education, 34(2), 143-155.

Kaufman, R. R. \& Segura-Ubiergo, A. (2001). Globalization, domestic politics, and social spending in Latin America: A time-series cross-section analysis, 1973-97. World Politics, 53, 553-587. 
Levin, J. S. (2001). Globalizing the community college: Strategies of change in the twenty-first century. New York, NY: Palgrave.

Levin, J. S. (2003). Two British Columbia university colleges and the process of economic globalization. The Canadian Journal of Higher Education. 33(3), 5986.

Lindio-McGovern, L. (2007) Neo-liberal globalization in the Philippines: Its impact on Filipino women and their forms of resistance. Journal of Developing Societies, 23(1-2), 15-35.

Lipsey, M.W. (1990). Design sensitivity: Statistical power for experimental research. Newbury Park, CA: Sage Publications.

Louisy, P. (2001).Globalisation and comparative education: A Caribbean perspective. Comparative Education. 37(4), 425-438.

Marginson, S., \& Rhoades, G. (2002). Beyond national states, markets and systems of higher education: A glonacal agency heuristic. Higher Education, 43, 281-309.

McBurnie, G. (2001). Leveraging globalization as a policy paradigm for higher education. Higher Education in Europe, 26(1), 11- 26.

Meyers, L.S., Gamst, G. \& Guarino, A.J. (2006). Applied multivariate research. Thousand Oaks, CA: Sage Publications.

Mohamedbhai, G. (2002, September).Globalization and its implications on universities in developing countries. Paper presented at the Conference 'Globalization: What issues are at stake for universities?' Université Laval, Québec, Canada.

Mok, K. H. (2000). Reflecting globalization effects on local policy: Higher education reform in Taiwan. Journal of Education Policy, 15(6), 637-660.

Mott, W. H. (2004). Globalization: People, perspectives, and progress. Westport, CT: Praeger.

Myers, F. J. (2007), Globalization impacts Regional Colleges: Janusian institutions. Unpublished doctoral thesis, University of Calgary, Calgary, Alberta.

Neville, J. W., \& Saunders, P. (1998).Globalization and the return to education in Australia. Economic Record, 74(226), 279-285.

Nooruddin, I., \& Simmons, J. W. (2009). Openness, uncertainty, and social spending: Implications for the globalization of the welfare state debate. International Studies Quarterly, 53, 841-866.

Opello, W. C., \& Rosow, S. J. (2004). The nation-state and global order: A historical introduction to contemporary politics. Boulder, CO: Lynne Rienner. 
Organisation for Economic Cooperation and Development. (2005). OECD handbook on economic globalisation indicators 2005. Paris, France: OECD Publishing.

Podesta, F. (2002). Recent developments in quantitative comparative methodology: The case of pooled time series-cross section analysis. (DSS Papers SOC 3-02).

Potrafke, N. (2009). Did globalization restrict partisan politics? An empirical evaluation of social expenditures in a panel of OECD countries. Public Choice, 140, 105124.

Raab, M., Ruland, M., Schönberger, B., Blossfeld, H.-P., Hofäcker, Buchholz, S., \& Schmelzer, P. (2008).GlobalIndex: A sociological approach to globalization measurement. International Sociology, 23 (4), 596-631.

Ramanathan, R. (1992). Introductory econometrics. Forth Worth, TX: The Dryden Press.

Roberts, V. (2001). Global trends in tertiary education quality assurance: Implications for the Anglophone Caribbean. Educational Management and Administration, 29(4), 425-440.

Roberts, V. (2003).The shaping of tertiary education in the Anglophone Caribbean: Forces, forms and functions. London: Commonwealth Secretariat.

Rudra, N., \& Haggard, S. (2005). Globalization, democracy, and effective welfare spending in the developing world. Comparative Political Studies, 38, 1015-1049.

Saahhdong, C. I. (2010). The relationship between globalization and public spending: Empirical evidence from the Nordic countries. Unpublished master's thesis, Lund University, Lund, Sweden.

Scholte, J.A. (2000).Globalization: A critical introduction. New York: St. Martin's Press.

Segura-Ubiergo, A. (2007). The political economy of the welfare state in Latin America: Globalization, democracy, and development. New York: Cambridge University Press.

Shapoatov, S. , 2009-04-02 The Impact of Globalization and Democratization on Social Spending in East Asia. Paper presented at the annual meeting of the Midwest Political Science Association 67th Annual National Conference, The Palmer House Hilton, Chicago, ILOnline <PD F>. 2010-09-29 from http://www.allacademic.com/meta/p361882_index.html

Slaughter, S., \& Rhoades, G. (2004). Academic capitalism and the new economy: Markets, state, and higher education. Baltimore: Johns Hopkins University Press.

Spector, P. E. (1981). Research designs. Newbury Park, CA: Sage Publications. Spring, J. (2008).Research on globalization and education. Review of Educational Research, 78(2), 330-363. 
Takahashi, Y., 2004-09-02 "Determinants of Social Spending in Latin America: Globalization, Political Institutions, and Labor Market" Paper presented at the annual meeting of the American Political Science Association, Hilton Chicago and the Palmer House Hilton, Chicago, ILOnline <.PDF>. 2009-05-26 from http://www.allacademic.com/meta/p59679_index.html

Tikly, L. (2001). Globalisation and education in the postcolonial world: Towards a conceptual framework. Comparative Education, 37(2), 151-171.

Tomlinson, J. (1991). Cultural imperialism: A critical introduction. Baltimore, MD: Johns Hopkins University Press.

Torres, C. A. \& Schugurensky, D. (2002). The political economy of higher education in the era of neoliberal globalization: Latin America in comparative perspective. Higher Education, 43, 429-455.

Vaira, M. (2004). Globalization and higher education organizational change: A framework for analysis. Higher Education, 48, 483-510.

Vidovich, L. (2002, December). 'Acceding to audits': New quality assurance policy as a 'settlement' in fostering international markets for Australian higher education. Paper presented at the Australian Association for Research in Education Conference. Brisbane, Australia.

Waters, M. (2001).Globalization. London: Routledge.

Welch, A. R. (2001). Globalisation, post-modernity and the state: Comparative education facing the third millennium. Comparative Education, 37(4), 475-492.

Worrall, J. L. \& Pratt, T. C. (2004). Estimation issues associated with time-series-crosssection analysis in criminology. Western Criminology Review, 5 (1), 35-49.

Yang, R. (2003).Globalisation and higher education development: A critical analysis. International Review of Education, 49(3-4), 269-291.

Yoder, B. L. (2006). Globalization of higher education in eight Chinese universities: Incorporation of and strategic responses to world culture. Unpublished doctoral dissertation, University of Pittsburgh, Pennsylvania.

Zolo, D. (2007). Globalisation: An overview. Colchester, UK: ECPR Press. 
APPENDICES 


\section{Appendix A - List of variables and their sources}




\section{Appendix A}

\section{List of variables and their sources}

\begin{tabular}{|c|c|c|}
\hline $\begin{array}{l}\text { Higher Education } \\
\text { Indicators }\end{array}$ & Definition & Source \\
\hline $\begin{array}{l}\text { Spending on higher } \\
\text { education }\end{array}$ & $\begin{array}{l}\text { Higher education spending per } \\
\text { student as a \% of GDP per capita } \\
\text { (SPENDGDPCAP) } \\
\text { Higher education as a percentage of } \\
\text { total government education } \\
\text { spending (SPENDTOT) }\end{array}$ & $\begin{array}{l}\text { UNESCO Institute } \\
\text { for Statistics 1971- } \\
2009 \text {. } \\
\text { UNESCO Institute } \\
\text { for Statistics 1970- } \\
2009 \text {. }\end{array}$ \\
\hline Participation & $\begin{array}{l}\text { Gross enrollment ratio in higher } \\
\text { education (PARTIC) }\end{array}$ & $\begin{array}{l}\text { UNESCO Institute } \\
\text { for Statistics 1970- } \\
2009 \text {. }\end{array}$ \\
\hline Educational attainment & $\begin{array}{l}\text { Average years of tertiary schooling } \\
\text { of the population (ATTAINY) } \\
\text { Percentage of population } 15 \text { years } \\
\text { and over attaining education at the } \\
\text { tertiary level (ATTAINP) }\end{array}$ & $\begin{array}{l}\text { Barro and Lee } \\
(2010)\end{array}$ \\
\hline Gender Equity & $\begin{array}{l}\text { Ratio of females to males enrolled } \\
\text { in higher education (GENEQUGER) } \\
\text { Ratio of females to males } \\
\text { completing higher education } \\
\text { (GENEQUC) }\end{array}$ & $\begin{array}{l}\text { UNESCO Institute } \\
\text { for Statistics 1970- } \\
2009 . \\
\text { Barro and Lee } \\
(2010)\end{array}$ \\
\hline Globalization Indicators & Definition & Source \\
\hline KOF Index & $\begin{array}{l}\text { Index constructed with principal } \\
\text { components. (KOF). Comprises } 23 \\
\text { variables measuring globalization. } \\
\text { Economic globalization (ECONG) } \\
\text { Political Globalization (POLG) } \\
\text { Technological Globalization } \\
\text { (TECG) } \\
\text { Cultural Globalization(CULG) }\end{array}$ & $\begin{array}{l}\text { KOF Swiss } \\
\text { Economic Institute }\end{array}$ \\
\hline Trade & $\begin{array}{l}\text { Sum of imports and exports of } \\
\text { goods and services as a percentage } \\
\text { of GDP (TRADE) }\end{array}$ & UNCTAD \\
\hline $\begin{array}{l}\text { Foreign Direct Investment } \\
(\mathrm{FDI})\end{array}$ & $\begin{array}{l}\text { Inflows of FDI as a share of GDP } \\
\text { (FDI) }\end{array}$ & World Bank \\
\hline
\end{tabular}




\begin{tabular}{|c|c|c|}
\hline Control variables & Definition & Source \\
\hline Economic & $\begin{array}{l}\text { Economic growth (GROWTH) } \\
\text { GDP per capita (GDPPCAP) } \\
\text { Total education expenditure per } \\
\text { student as a percent of GDP per } \\
\text { capita (TOTEDEXP) } \\
\text { Urbanization (URBAN) } \\
\text { Capital intensity (CAPSTOCK) }\end{array}$ & $\begin{array}{l}\text { Penn World Tables } \\
\text { Penn World Tables } \\
\text { UNESCO Institute } \\
\text { for Statistics 1970- } \\
2009 \\
\text { World } \\
\text { Development } \\
\text { Indicators } \\
\text { World Bank }\end{array}$ \\
\hline \multirow[t]{3}{*}{ Demographic } & $\begin{array}{l}\text { Population shares of higher } \\
\text { education age group in total } \\
\text { population (POPSHARE) }\end{array}$ & $\begin{array}{l}\text { UNESCO Institute } \\
\text { for Statistics 1970- } \\
2009\end{array}$ \\
\hline & $\begin{array}{l}\text { Lagged secondary gross enrollment } \\
\text { rates (SGERL) }\end{array}$ & $\begin{array}{l}\text { UNESCO Institute } \\
\text { for Statistics 1970- } \\
2009\end{array}$ \\
\hline & $\begin{array}{l}\text { Lagged } \% \text { of population with } \\
\text { secondary education attained. (SAL) }\end{array}$ & $\begin{array}{l}\text { Barro and Lee } \\
(2010)\end{array}$ \\
\hline Political & $\begin{array}{l}\text { Democracy/popularly based } \\
\text { government (DEMOCRACY): } \\
\text { Gurr's polity index subtract } \\
\text { AUTOC score from DEMOC score }\end{array}$ & Gurr's Polity IV \\
\hline
\end{tabular}


APPENDIX B - KOF Globalization Index 


\section{APPENDIX B - 2010 KOF Index of Globalization \\ Indices and Variables}

Weights

A. Economic Globalization

[37\%]

i) Actual Flows $\quad(50 \%)$

Trade (percent of GDP) $\quad(19 \%)$

Foreign Direct Investment, flows (percent of GDP) $\quad(20 \%)$

Foreign Direct Investment, stocks (percent of GDP) $\quad$ (24\%)

Portfolio Investment (percent of GDP)

Income Payments to Foreign Nationals (percent of GDP) $\quad(20 \%)$

ii) Restrictions

$(50 \%)$

Hidden Import Barriers $\quad(22 \%)$

Mean Tariff Rate $\quad(28 \%)$

Taxes on International Trade (percent of current revenue) (27\%)

Capital Account Restrictions

B. Social Globalization

i) Data on Personal Contact

Telephone Traffic (26\%)

Transfers (percent of GDP)

International Tourism $\quad(26 \%)$

Foreign Population (percent of total population) $\quad(20 \%)$

International letters (per capita) $\quad(25 \%)$

ii) Data on Information Flows

Internet Users (per 1000 people) $\quad(36 \%)$

Television (per 1000 people) $\quad(36 \%)$

Trade in Newspapers (percent of GDP) $\quad(28 \%)$

iii) Data on Cultural Proximity

Number of McDonald's Restaurants (per capita) $\quad$ (43\%)

Number of Ikea (per capita)

Trade in books (percent of GDP)

C. Political Globalization

[25\%]

Embassies in Country

$(25 \%)$

Membership in International Organizations

$(28 \%)$

Participation in U.N. Security Council Missions

$(22 \%)$

International Treaties

$(25 \%)$

Source: Dreher, Axel, 2006, Does Globalization Affect Growth? Empirical Evidence from a new Index, Applied Economics 38, 10: 1091-1110. Updated in: Dreher, Axel; Noel Gaston and Pim Martens, 2008, Measuring Globalization-Gauging its Consequence, New York: Springer. 
APPENDIX C - List of Countries included in the study 


\section{APPENDIX C}

\section{List of Countries included in the study}

\begin{tabular}{|c|c|c|c|}
\hline Albania & Dominica & Macao, China & Spain \\
\hline Algeria & Dominican & Madagascar & Sri Lanka \\
\hline Angola & Republic & Malawi & St. Kitts and Nevis \\
\hline Argentina & Ecuador & Malaysia & St. Lucia \\
\hline Australia & Egypt, Arab Rep. & Mali & Sudan \\
\hline Austria & El Salvador & Malta & Suriname \\
\hline Bahamas, The & Ethiopia & Marshall Islands & Swaziland \\
\hline Bahrain & Fiji & Mauritania & Sweden \\
\hline Bangladesh & Finland & Mauritius & Switzerland \\
\hline Barbados & France & Mexico & Syrian Arab \\
\hline Belgium & Gabon & Mongolia & Republic \\
\hline Belize & Gambia, The & Morocco & Thailand \\
\hline Benin & Georgia & Mozambique & Togo \\
\hline Bermuda & Germany & Namibia & Tonga \\
\hline Bhutan & Ghana & Nepal & Trinidad and \\
\hline Bolivia & Greece & Netherlands & Tobago \\
\hline Botswana & Grenada & New Zealand & Tunisia \\
\hline Brazil & Guatemala & Nicaragua & Turkey \\
\hline Brunei Darussalam & Guinea-Bissau & Niger & Uganda \\
\hline Bulgaria & Guyana & Nigeria & United Arab \\
\hline Burkina Faso & Honduras & Norway & Emirates \\
\hline Burundi & Hungary & Oman & United Kingdom \\
\hline Cameroon & Iceland & Pakistan & United States \\
\hline Canada & India & Panama & Uruguay \\
\hline Cape Verde & Indonesia & Papua New & Venezuela, RB \\
\hline Central African & Iran, Islamic Rep. & Guinea & Vietnam \\
\hline Republic & Israel & Paraguay & Zambia \\
\hline Chad & Italy & Peru & Zimbabwe \\
\hline Chile & Jamaica & Philippines & \\
\hline China & Japan & Portugal & \\
\hline Colombia & Jordan & Romania & \\
\hline Comoros & Kenya & Rwanda & \\
\hline Congo, Dem. Rep. & Korea, Rep. & Samoa & \\
\hline Congo, Rep. & Lao PDR & Saudi Arabia & \\
\hline Costa Rica & Latvia & Senegal & \\
\hline Cote d'Ivoire & Lesotho & Seychelles & \\
\hline Cuba & Liberia & Sierra Leone & \\
\hline Cyprus & Libya & Singapore & \\
\hline Denmark & Luxembourg & South Africa & \\
\hline
\end{tabular}


APPENDIX D - SUMMARY STATISTICS 


\section{APPENDIX D}

\begin{tabular}{|l|r|r|r|r|r|}
\hline \multicolumn{7}{|c|}{ Descriptive Statistics: 1970-1974 } \\
\hline & \multicolumn{1}{|c|}{$\mathrm{N}$} & Minimum & Maximum & \multicolumn{1}{c|}{ Mean } & Std. Deviation \\
\hline KOF70 & 121 & 13.52 & 73.11 & 37.8339 & 14.34517 \\
\hline ECONG70 & 108 & 9.57 & 93.18 & 40.2421 & 17.32810 \\
\hline POLG70 & 122 & 1.28 & 97.37 & 42.4918 & 22.34710 \\
\hline TECG70 & 118 & 3.40 & 84.88 & 41.7746 & 21.52010 \\
\hline CULG70 & 122 & 1.00 & 62.73 & 10.1600 & 12.72623 \\
\hline FDI70 & 74 & -7.9028 & 26.8840 & 1.609751 & 3.9680093 \\
\hline TRADE70 & 103 & 7.2108 & 263.9955 & 58.902293 & 38.1821680 \\
\hline SAL70 & 117 & .2 & 42.1 & 7.628 & 7.9328 \\
\hline POPSHARE70 & 137 & 6.30 & 11.44 & 8.7106 & .89783 \\
\hline SGERL70 & 124 & 1.31 & 105.29 & 36.9419 & 28.86527 \\
\hline ATTAINP70 & 117 & .0 & 11.4 & 1.703 & 2.0743 \\
\hline ATTAINY70 & 117 & .002 & .646 & .09600 & .115430 \\
\hline GENEQUC70 & 115 & .0000 & 2.0723 & .359535 & .3049881 \\
\hline SPENTOT70 & 84 & 1.94 & 44.79 & 14.6968 & 7.70724 \\
\hline SPENDGDPCAP70 & 50 & 26.16 & 3331.85 & 485.6326 & 795.08752 \\
\hline GENEQUGER70 & 81 & .045 & 2.267 & .49711 & .368207 \\
\hline PARTIC70 & 93 & .539 & 48.247 & 7.89148 & 7.980947 \\
\hline TOTEDEXP70 & 39 & 6.96 & 68.62 & 20.9206 & 12.04697 \\
\hline URBAN70 & 139 & 2.72 & 100.00 & 42.0924 & 24.88799 \\
\hline GROWTH70 & 107 & -3.34 & 21.72 & 5.5168 & 3.61651 \\
\hline GDPPCAP70 & 108 & 130.15 & 31448.47 & 4479.6412 & 6239.23657 \\
\hline CAPSTOCK70 & 98 & 5.0 & 49.0 & 22.406 & 7.9140 \\
\hline DEMOCRACY70 & 112 & -10.0 & 10.0 & -1.552 & 7.3386 \\
\hline & & & & & \\
\hline
\end{tabular}




\begin{tabular}{|l|r|r|r|r|r|}
\hline \multicolumn{7}{|c|}{ Descriptive Statistics: 1975-1979 } \\
\hline & \multicolumn{1}{|c|}{$\mathrm{N}$} & \multicolumn{1}{c|}{ Minimum } & \multicolumn{1}{c|}{ Maximum } & \multicolumn{1}{c|}{ Mean } & Std. Deviation \\
\hline KOF75 & 129 & 13.12 & 78.08 & \multicolumn{1}{c|}{39.5003} & 14.88890 \\
\hline ECONG75 & 113 & 10.57 & 93.51 & 41.1835 & 17.62191 \\
\hline POLG75 & 130 & 1.28 & 97.35 & 46.9562 & 22.63728 \\
\hline TECG75 & 126 & 3.40 & 84.88 & 41.4300 & 21.30400 \\
\hline CULG75 & 130 & 1.00 & 85.78 & 13.5072 & 18.82007 \\
\hline FDI75 & 110 & -2.8760 & 28.3574 & 1.654328 & 4.1331322 \\
\hline TRADE75 & 114 & 11.8174 & 325.6802 & 70.687804 & 44.8534828 \\
\hline SAL75 & 117 & .3 & 44.5 & 9.386 & 8.8431 \\
\hline POPSHARE75 & 137 & 6.68 & 13.41 & 9.0637 & 1.08040 \\
\hline SGERL75 & 123 & 1.82 & 106.12 & 44.2126 & 29.34421 \\
\hline ATTAINP75 & 117 & .0 & 13.3 & 2.222 & 2.5133 \\
\hline ATTAINY75 & 117 & .0011 & .7999 & .127805 & .1435740 \\
\hline GENEQUC75 & 115 & .0000 & 2.3291 & .425057 & .3311370 \\
\hline SPENTOT75 & 87 & 2.03 & 37.34 & 18.1668 & 7.76168 \\
\hline SPENDGDPCAP75 & 66 & 22.03 & 4188.81 & 458.4166 & 708.43386 \\
\hline GENEQUGER75 & 92 & .051 & 6.893 & .64967 & .773709 \\
\hline PARTIC75 & 107 & .597 & 52.896 & 9.99754 & 10.593325 \\
\hline TOTEDEXP75 & 50 & 4.60 & 68.37 & 21.6080 & 12.19111 \\
\hline URBAN75 & 139 & 3.67 & 100.00 & 44.6142 & 24.79746 \\
\hline GROWTH75 & 117 & -4.18 & 15.24 & 4.6465 & 3.49708 \\
\hline GDPPCAP75 & 117 & 145.52 & 54955.37 & 5443.8472 & 8319.86401 \\
\hline CAPSTOCK75 & 109 & 7.0 & 52.4 & 24.559 & 7.7241 \\
\hline DEMOCRACY75 & 118 & -10.0 & 10.0 & -1.612 & 7.4276 \\
\hline & & & & & \\
\hline
\end{tabular}




\begin{tabular}{|l|r|r|r|r|r|}
\hline \multicolumn{7}{|c|}{ Descriptive Statistics: 1980-1984 } \\
\hline & \multicolumn{1}{c|}{$\mathrm{N}$} & \multicolumn{1}{|c|}{ Minimum } & Maximum & \multicolumn{1}{c|}{ Mean } & Std. Deviation \\
\hline KOF80 & 133 & 14.08 & 82.13 & 41.2440 & 15.60056 \\
\hline ECONG80 & 115 & 10.97 & 94.10 & 43.5844 & 18.16702 \\
\hline POLG80 & 134 & 1.28 & 97.23 & 48.3701 & 22.06903 \\
\hline TECG80 & 130 & 3.40 & 84.88 & 41.8742 & 21.33705 \\
\hline CULG80 & 134 & 1.00 & 91.56 & 17.0029 & 23.11002 \\
\hline FDI80 & 119 & -1.4773 & 24.6818 & 1.419642 & 3.1089033 \\
\hline TRADE80 & 129 & 9.1057 & 367.3659 & 74.856967 & 49.9155401 \\
\hline SAL80 & 117 & .5 & 49.0 & 11.534 & 9.6982 \\
\hline POPSHARE80 & 137 & 6.71 & 12.03 & 9.2312 & 1.20989 \\
\hline SGERL80 & 125 & 2.67 & 109.40 & 50.5049 & 30.82327 \\
\hline ATTAINP80 & 117 & .0 & 16.7 & 2.751 & 3.0047 \\
\hline ATTAINY80 & 117 & .0000 & .9329 & .157931 & .1680642 \\
\hline GENEQUC80 & 115 & .0000 & 2.6346 & .538745 & .4115704 \\
\hline SPENTOT80 & 84 & 1.20 & 38.23 & 18.4077 & 7.93015 \\
\hline SPENDGDPCAP80 & 74 & 16.39 & 2679.39 & 310.8987 & 478.85668 \\
\hline GENEQUGER80 & 90 & .100 & 3.377 & .72060 & .554175 \\
\hline PARTIC80 & 112 & .512 & 56.229 & 11.34998 & 10.847246 \\
\hline TOTEDEXP80 & 53 & 5.33 & 62.86 & 21.4268 & 10.13532 \\
\hline URBAN80 & 139 & 4.69 & 100.00 & 46.9587 & 24.65713 \\
\hline GROWTH80 & 135 & -6.02 & 14.34 & 2.6363 & 3.41285 \\
\hline GDPPCAP80 & 137 & 141.10 & 53716.82 & 5470.0529 & 8513.97946 \\
\hline CAPSTOCK80 & 129 & 3.7 & 64.0 & 24.398 & 8.7188 \\
\hline DEMOCRACY80 & 118 & -10.0 & 10.0 & -1.069 & 7.5213 \\
\hline & & & & & \\
\hline
\end{tabular}




\begin{tabular}{|l|r|r|r|r|r|}
\hline \multicolumn{7}{|c|}{ Descriptive Statistics:1985-1989 } \\
\hline & \multicolumn{1}{|c|}{$\mathrm{N}$} & \multicolumn{1}{|c|}{ Minimum } & Maximum & \multicolumn{1}{c|}{ Mean } & Std. Deviation \\
\hline KOF85 & 133 & 14.32 & 84.46 & 42.5656 & 16.16539 \\
\hline ECONG85 & 115 & 10.24 & 94.84 & 45.5161 & 18.58105 \\
\hline POLG85 & 135 & 1.28 & 94.28 & 48.8762 & 21.18356 \\
\hline TECG85 & 130 & 3.40 & 84.88 & 41.8762 & 21.33596 \\
\hline CULG85 & 135 & 1.00 & 93.25 & 20.7796 & 26.53424 \\
\hline FDI85 & 126 & -16.6365 & 37.8154 & 1.534642 & 4.6647832 \\
\hline TRADE85 & 132 & 13.0438 & 327.3004 & 71.254360 & 45.6677038 \\
\hline SAL85 & 117 & .0 & 41.8 & 13.231 & 9.6615 \\
\hline POPSHARE85 & 137 & 6.15 & 12.29 & 9.0861 & 1.16890 \\
\hline SGERL85 & 127 & 3.83 & 116.30 & 54.3743 & 31.62652 \\
\hline ATTAINP85 & 117 & .1 & 18.6 & 3.538 & 3.5719 \\
\hline ATTAINY85 & 117 & .0035 & 1.1198 & .200106 & .1985767 \\
\hline GENEQUC85 & 117 & .0000 & 5.0131 & .632696 & .5670242 \\
\hline SPENTOT85 & 83 & 1.20 & 41.69 & 17.5633 & 8.27032 \\
\hline SPENDGDPCAP85 & 74 & 10.66 & 2134.49 & 221.7012 & 375.14511 \\
\hline GENEQUGER85 & 86 & .093 & 2.907 & .76721 & .494231 \\
\hline PARTIC85 & 118 & .596 & 76.586 & 13.40665 & 13.301483 \\
\hline TOTEDEXP85 & 53 & 3.29 & 36.31 & 18.7591 & 7.41992 \\
\hline URBAN85 & 139 & 5.20 & 100.00 & 49.1990 & 24.49105 \\
\hline GROWTH85 & 138 & -6.45 & 11.94 & 3.4168 & 2.84433 \\
\hline GDPPCAP85 & 138 & 129.28 & 43383.58 & 5727.1691 & 8510.08496 \\
\hline CAPSTOCK85 & 131 & 7.8 & 54.6 & 22.302 & 7.6965 \\
\hline DEMOCRACY85 & 117 & -10.0 & 10.0 & -.458 & 7.5769 \\
\hline & & & & & \\
\hline
\end{tabular}




\begin{tabular}{|l|r|r|r|r|r|}
\hline \multicolumn{7}{|c|}{ Descriptive Statistics: 1990-1994 } \\
\hline & \multicolumn{1}{c|}{$\mathrm{N}$} & \multicolumn{1}{|c|}{ Minimum } & Maximum & \multicolumn{1}{c|}{ Mean } & Std. Deviation \\
\hline KOF90 & 136 & 14.82 & 87.89 & 45.7439 & 17.00661 \\
\hline ECONG90 & 118 & 10.03 & 95.10 & 48.7488 & 18.39696 \\
\hline POLG90 & 138 & 2.22 & 96.09 & 53.9147 & 22.71319 \\
\hline TECG90 & 133 & 3.40 & 86.87 & 43.3476 & 22.17178 \\
\hline CULG90 & 138 & 1.00 & 94.84 & 24.3202 & 27.81544 \\
\hline FDI90 & 134 & -8.8287 & 64.3385 & 2.257051 & 6.0448887 \\
\hline TRADE90 & 139 & 1.1284 & 86.8088 & 30.821731 & 15.9120206 \\
\hline SAL90 & 117 & .5 & 41.6 & 15.389 & 10.3971 \\
\hline POPSHARE90 & 137 & 6.52 & 11.26 & 8.9439 & 1.05822 \\
\hline SGERL90 & 124 & 5.70 & 132.85 & 59.7121 & 33.09729 \\
\hline ATTAINP90 & 117 & .1 & 20.9 & 4.140 & 4.1061 \\
\hline ATTAINY90 & 117 & .0068 & 1.2807 & .232072 & .2254732 \\
\hline GENEQUC90 & 117 & .0000 & 4.1301 & .688536 & .5116821 \\
\hline SPENTOT90 & 89 & 2.99 & 34.60 & 18.3465 & 7.24275 \\
\hline SPENDGDPCAP90 & 67 & 7.56 & 1450.95 & 155.7180 & 261.20931 \\
\hline GENEQUGER90 & 89 & .077 & 2.167 & .83354 & .422031 \\
\hline PARTIC90 & 113 & .567 & 91.990 & 17.05912 & 16.676232 \\
\hline TOTEDEXP90 & 57 & 4.31 & 52.89 & 20.4646 & 9.41110 \\
\hline URBAN90 & 139 & 6.57 & 100.00 & 51.2416 & 24.34656 \\
\hline GROWTH90 & 138 & -31.02 & 10.86 & 2.1285 & 5.25603 \\
\hline GDPPCAP90 & 138 & 114.08 & 42749.73 & 6160.0645 & 9089.67545 \\
\hline CAPSTOCK90 & 132 & 6.4 & 66.4 & 22.198 & 8.4011 \\
\hline DEMOCRACY90 & 121 & -10.0 & 10.0 & 2.383 & 6.7266 \\
\hline & & & & & \\
\hline
\end{tabular}




\begin{tabular}{|l|r|r|r|r|r|}
\hline \multicolumn{7}{|c|}{ Descriptive Statistics: 1995-1999 } \\
\hline & \multicolumn{1}{c|}{$\mathrm{N}$} & \multicolumn{1}{|c|}{ Minimum } & Maximum & \multicolumn{1}{c|}{ Mean } & Std. Deviation \\
\hline KOF95 & 137 & 17.02 & 91.57 & 50.7979 & 17.54848 \\
\hline ECONG95 & 119 & 15.50 & 96.52 & 53.6830 & 18.54735 \\
\hline POLG95 & 139 & 3.49 & 97.20 & 59.4950 & 22.47518 \\
\hline TECG95 & 134 & 7.06 & 93.25 & 50.3960 & 22.39445 \\
\hline CULG95 & 139 & 1.00 & 96.17 & 31.2996 & 29.18501 \\
\hline FDI95 & 136 & -4.1729 & 173.3960 & 4.610817 & 15.1887999 \\
\hline TRADE95 & 136 & 16.5796 & 335.4870 & 78.101836 & 45.0718519 \\
\hline SAL90 & 117 & .5 & 41.6 & 15.389 & 10.3971 \\
\hline POPSHARE95 & 138 & 5.58 & 11.31 & 8.8272 & 1.23401 \\
\hline SGERL95 & 123 & 6.24 & 150.50 & 66.7996 & 33.65668 \\
\hline ATTAINP95 & 117 & .1 & 22.0 & 4.940 & 4.7106 \\
\hline ATTAINY95 & 117 & .0079 & 1.3248 & .275979 & .2543530 \\
\hline GENEQUC95 & 117 & .0894 & 3.1149 & .743804 & .4479715 \\
\hline SPENTOT95 & 92 & 1.51 & 40.73 & 18.3927 & 7.86577 \\
\hline SPENDGDPCAP95 & 77 & 7.01 & 2060.34 & 149.5201 & 323.69586 \\
\hline GENEQUGER95 & 97 & .121 & 2.708 & .97295 & .505421 \\
\hline PARTIC95 & 117 & .571 & 75.732 & 21.21126 & 19.867166 \\
\hline TOTEDEXP95 & 79 & 4.47 & 52.00 & 19.2384 & 7.26694 \\
\hline URBAN95 & 139 & 7.63 & 100.00 & 52.9753 & 24.19989 \\
\hline GROWTH95 & 138 & -5.74 & 33.35 & 3.9094 & 3.51907 \\
\hline GDPPCAP95 & 139 & 102.90 & 47901.43 & 6746.5929 & 9883.35804 \\
\hline CAPSTOCK95 & 132 & 5.6 & 64.4 & 22.280 & 7.7129 \\
\hline DEMOCRACY95 & 121 & -10.0 & 10.0 & 3.278 & 6.4131 \\
\hline & & & & & \\
\hline
\end{tabular}




\begin{tabular}{|l|r|r|r|r|r|}
\hline \multicolumn{7}{|c|}{ Descriptive Statistics: 2000-2004 } \\
\hline & \multicolumn{1}{c|}{$\mathrm{N}$} & Minimum & Maximum & \multicolumn{1}{c|}{ Mean } & Std. Deviation \\
\hline KOF00 & 137 & 20.18 & 92.37 & 54.7911 & 17.06803 \\
\hline ECONG00 & 119 & 25.44 & 97.88 & 58.4084 & 17.79240 \\
\hline POLG00 & 138 & 3.71 & 97.17 & 63.2148 & 22.39982 \\
\hline TECG00 & 134 & 19.51 & 95.54 & 57.9315 & 19.10638 \\
\hline CULG00 & 139 & 1.00 & 97.27 & 33.4995 & 30.48457 \\
\hline FDI00 & 139 & -7.0848 & 388.4430 & 6.501713 & 32.8884257 \\
\hline TRADE00 & 136 & 21.6563 & 378.3610 & 83.555665 & 48.0939763 \\
\hline SAL00 & 117 & .6 & 57.8 & 19.108 & 12.2163 \\
\hline POPSHARE00 & 138 & 5.65 & 12.21 & 8.9371 & 1.53076 \\
\hline SGERL00 & 131 & 7.40 & 155.17 & 71.2849 & 32.91095 \\
\hline ATTAINP00 & 117 & .2 & 26.4 & 5.574 & 5.3594 \\
\hline ATTAINY00 & 117 & .0101 & 1.4968 & .308887 & .2835735 \\
\hline GENEQUC00 & 117 & .1222 & 7.5862 & .879952 & .8178330 \\
\hline SPENTOT00 & 72 & 2.95 & 36.70 & 18.6701 & 8.38362 \\
\hline SPENDGDPCAP00 & 82 & 7.35 & 2186.53 & 130.6788 & 296.95698 \\
\hline GENEQUGER00 & 108 & .152 & 2.753 & 1.04884 & .515224 \\
\hline PARTIC00 & 118 & .507 & 85.681 & 25.77644 & 22.971627 \\
\hline TOTEDEXP00 & 99 & 6.48 & 48.40 & 19.7620 & 7.40495 \\
\hline URBAN00 & 139 & 8.70 & 100.00 & 54.6299 & 24.08421 \\
\hline GROWTH00 & 139 & -6.66 & 13.52 & 3.7941 & 2.58157 \\
\hline GDPPCAP00 & 139 & 85.21 & 58936.43 & 7509.1404 & 11176.98039 \\
\hline CAPSTOCK00 & 134 & 6.2 & 55.4 & 21.243 & 6.9226 \\
\hline DEMOCRACY00 & 121 & -10.0 & 10.0 & 3.899 & 6.2009 \\
\hline & & & & & \\
\hline
\end{tabular}




\begin{tabular}{|l|r|r|r|r|r|}
\hline \multicolumn{7}{|c|}{ Descriptive Statistics: 2005-2009 } \\
\hline & \multicolumn{1}{c|}{$\mathrm{N}$} & Minimum & Maximum & \multicolumn{1}{c|}{ Mean } & Std. Deviation \\
\hline KOF05 & 137 & 23.80 & 92.50 & 57.7821 & 16.22872 \\
\hline ECONG05 & 119 & 26.03 & 96.52 & 61.7703 & 17.10592 \\
\hline POLG05 & 139 & 4.09 & 97.90 & 68.0702 & 21.16210 \\
\hline TECG05 & 134 & 25.97 & 97.72 & 60.5595 & 17.59924 \\
\hline CULG05 & 139 & 1.00 & 96.78 & 34.2268 & 31.69603 \\
\hline FDI05 & 139 & -4.4158 & 312.8250 & 7.602762 & 26.5880592 \\
\hline TRADE05 & 137 & 25.3896 & 430.8142 & 90.558463 & 51.2906081 \\
\hline SAL05 & 117 & .6 & 62.6 & 21.398 & 13.3407 \\
\hline POPSHARE05 & 135 & 5.18 & 13.01 & 8.9540 & 1.66498 \\
\hline SGERL05 & 131 & 10.56 & 128.16 & 74.4205 & 29.94699 \\
\hline ATTAINP05 & 117 & .1 & 21.8 & 6.090 & 5.5382 \\
\hline ATTAINY05 & 117 & .0078 & 1.3635 & .340509 & .2927931 \\
\hline GENEQUC05 & 116 & .1963 & 3.0952 & .902277 & .5272115 \\
\hline SPENTOT05 & 73 & .17 & 39.45 & 19.0325 & 8.22912 \\
\hline SPENDGDPCAP05 & 84 & 9.81 & 1331.06 & 89.0626 & 163.90886 \\
\hline GENEQUGER05 & 105 & .128 & 3.352 & 1.12707 & .561008 \\
\hline PARTIC05 & 113 & .514 & 100.100 & 31.50098 & 27.028170 \\
\hline TOTEDEXP05 & 88 & 7.73 & 50.19 & 20.1071 & 7.79545 \\
\hline URBAN05 & 139 & 9.88 & 100.00 & 56.3311 & 24.04521 \\
\hline GROWTH05 & 139 & -4.90 & 15.56 & 3.9695 & 2.81598 \\
\hline GDPPCAP05 & 139 & 97.46 & 65272.21 & 8260.8204 & 12065.85008 \\
\hline CAPSTOCK05 & 135 & 3.6 & 43.8 & 23.341 & 6.5536 \\
\hline DEMOCRACY05 & 121 & -10.0 & 10.0 & 4.269 & 5.9951 \\
\hline & & & & & \\
\hline
\end{tabular}


APPENDIX E - REGRESSION RESULTS 


\section{Hypothesis 1- Alternative measures of globalization}

Table 1

Multiple Regression Results: Higher education spending and alternative globalization measure (FDI). (Spending-SPENDGDPPCAP)

\begin{tabular}{|c|c|c|c|c|c|c|c|c|}
\hline Variable & $\begin{array}{l}1970- \\
74\end{array}$ & $\begin{array}{l}1975- \\
79\end{array}$ & $\begin{array}{l}1980- \\
84\end{array}$ & $\begin{array}{l}1985- \\
89\end{array}$ & $\begin{array}{l}1990- \\
94\end{array}$ & $\begin{array}{l}1995- \\
99\end{array}$ & $\begin{array}{l}2000- \\
04\end{array}$ & $\begin{array}{l}2005- \\
09\end{array}$ \\
\hline FDI & .11 & $.29 *$ & -.00 & -.02 & -.14 & .30 & -.06 & .02 \\
\hline GDPPCAP & -.22 & .15 & -.21 & -.28 & -.11 & .09 & -.05 & .09 \\
\hline CAPSTOCK & -.08 & -.15 & .01 & .08 & .07 & -.28 & .05 & -.08 \\
\hline GROWTH & .07 & -.04 & -.04 & .10 & -.09 & .19 & -.05 & -.10 \\
\hline DEMOCRACY & .46 & -.15 & .01 & -.16 & $-.31 *$ & .05 & -.01 & .11 \\
\hline POPSHARE & -.19 & -.15 & $-.38 *$ & $-.45 * *$ & -.20 & -.11 & -.23 & .23 \\
\hline PARTIC & -.70 & $-.62 *$ & $-.54 * *$ & $-.37 *$ & -.31 & $-.55 * *$ & $-.54 *$ & $-.40 *$ \\
\hline$R^{2}$ & .46 & $.45 * *$ & $.39 * *$ & $.42 * *$ & $.34 * *$ & $.29 * *$ & .17 & $.20 *$ \\
\hline$N$ & 23 & 49 & 60 & 61 & 59 & 68 & 72 & 76 \\
\hline
\end{tabular}

Notes: ${ }^{*} p<.05 .{ }^{* *} p<.01$. Standardized coefficients. Dependent variable: SPENDGDPPCAP - spending on higher education per student as a percentage of GDP per capita. Globalization variable - FDI (foreign direct investment). Control variables: GDP per capita (GDPPCAP), capital intensity (CAPSTOCK), economic growth (GROWTH), politics (DEMOCRACY), population share in higher education (POPSHARE), gross enrolment in higher education (PARTIC).

Table 2

Multiple Regression Results: Higher education spending and alternative globalization measure (TRADE). (Spending- SPENDGDPPCAP)

\begin{tabular}{|l|l|l|l|l|l|l|l|l|}
\hline Variable & $1970-$ & $1975-$ & $1980-$ & $1985-$ & $1990-$ & $1995-$ & $2000-$ & $2005-$ \\
& 74 & 79 & 84 & 89 & 94 & 99 & 04 & 09 \\
\hline TRADE & $.35^{*}$ & .18 & .14 & .13 & -.35 & -.07 & -.06 & .16 \\
\hline GDPPCAP & .70 & .12 & -.05 & -.15 & .05 & -.01 & -.05 & .10 \\
\hline CAPSTOCK & $-.45^{*}$ & -.16 & -.18 & .00 & .05 & -.05 & .07 & -.11 \\
\hline GROWTH & -.01 & -.02 & .05 & .11 & -.08 & .17 & -.10 & -.08 \\
\hline DEMOCRACY & -.25 & -.21 & -.03 & -.20 & -.27 & .13 & -.03 & .13 \\
\hline POPSHARE & .05 & -.17 & $-.28^{*}$ & $-.34^{*}$ & -.24 & -.24 & -.21 & .24 \\
\hline PARTIC & $-.75^{*}$ & -.57 & $-.59^{* *}$ & $-.39^{*}$ & -.19 & $-.64^{* *}$ & $-.53^{*}$ & $-.39^{*}$ \\
\hline$R^{2}$ & $.52^{* *}$ & $.41^{* *}$ & $.39^{* *}$ & $.34^{* *}$ & $.35^{* *}$ & $.25^{*}$ & .17 & $.23^{*}$ \\
\hline$N$ & 37 & 52 & 64 & 64 & 60 & 69 & 72 & 76 \\
\hline
\end{tabular}

Notes: ${ }^{*} p<.05 .{ }^{* *} p<.01$. Standardized coefficients. Dependent variable: SPENDGDPPCAP - spending on higher education per student as a percentage of GDP per capita. Globalization variable - TRADE (trade in goods). Control variables: GDP per capita (GDPPCAP), capital intensity (CAPSTOCK), economic growth (GROWTH), politics (DEMOCRACY), population share in higher education (POPSHARE), gross enrolment in higher education (PARTIC). 
Table 3

Multiple Regression Results: Higher education spending and alternative globalization measure (FDI). (Spending- SPENDTOT)

\begin{tabular}{|l|l|l|l|l|l|l|l|l|}
\hline Variable & $1970-$ & $1975-$ & $1980-$ & $1985-$ & $1990-$ & $1995-$ & $2000-$ & $2005-$ \\
& 74 & 79 & 84 & 89 & 94 & 99 & 04 & 09 \\
\hline FDI & .12 & -.08 & -.07 & -.10 & -.23 & -.13 & .07 & .04 \\
\hline GDPPCAP & $-.13^{*}$ & -.22 & .01 & .19 & .26 & $.60^{*}$ & .35 & -.05 \\
\hline CAPSTOCK & -.20 & -.01 & -.05 & -.06 & .04 & -.21 & -.35 & -.17 \\
\hline GROWTH & $.57^{*}$ & .28 & .24 & .11 & -.09 & .06 & .14 & -.17 \\
\hline DEMOCRACY & $1.09^{* *}$ & .01 & -.07 & -.26 & -.28 & .01 & .13 & -.02 \\
\hline POPSHARE & -.34 & .02 & .26 & .16 & .28 & .22 & .25 & -.19 \\
\hline PARTIC & .50 & .15 & .08 & .08 & .28 & -.25 & .09 & .07 \\
\hline$R^{2}$ & .42 & .11 & .12 & .06 & .17 & .18 & .20 & .17 \\
\hline$N$ & 31 & 51 & 54 & 59 & 65 & 64 & 54 & 54 \\
\hline
\end{tabular}

Notes: ${ }^{*} p<.05 .{ }^{* *} p<.01$. Standardized coefficients. Dependent variable: SPENDTOT - spending on higher education as a percentage of total government education spending. Globalization variable - FDI (foreign direct investment). Control variables: GDP per capita (GDPPCAP), capital intensity (CAPSTOCK), economic growth (GROWTH), politics (DEMOCRACY), population share in higher education (POPSHARE), gross enrolment in higher education (PARTIC).

Table 4

Multiple Regression Results: Higher education spending and alternative globalization measure (TRADE). (Spending- SPENDTOT)

\begin{tabular}{|l|l|l|l|l|l|l|l|l|}
\hline Variable & $1970-$ & $1975-$ & $1980-$ & $1985-$ & $1990-$ & $1995-$ & $2000-$ & $2005-$ \\
& 74 & 79 & 84 & 89 & 94 & 99 & 04 & 09 \\
\hline TRADE & -.16 & -.03 & .10 & .08 & .17 & -.02 & -.15 & -.02 \\
\hline GDPPCAP & $-.73^{*}$ & -.18 & .02 & .20 & .25 & $.63^{*}$ & .41 & -.07 \\
\hline CAPSTOCK & -.14 & -.02 & -.18 & -.09 & -.04 & $-.31^{*}$ & -.33 & -.15 \\
\hline GROWTH & $.46^{*}$ & .25 & .25 & .07 & -.04 & .06 & .18 & -.18 \\
\hline DEMOCRACY & $.86^{* *}$ & .04 & -.08 & -.26 & -.32 & .03 & .15 & -.01 \\
\hline POPSHARE & -.15 & .05 & .27 & .16 & .24 & .24 & .29 & -.20 \\
\hline PARTIC & .31 & .14 & .08 & .00 & .16 & -.24 & .09 & .07 \\
\hline$R^{2}$ & $.29^{*}$ & .09 & .12 & .05 & .12 & .18 & .22 & .17 \\
\hline$N$ & 48 & 53 & 57 & 60 & 67 & 66 & 54 & 54 \\
\hline
\end{tabular}

Notes: ${ }^{*} p<.05 .{ }^{* *} p<.01$. Standardized coefficients. Dependent variable: SPENDTOT - spending on higher education as a percentage of total government education spending. Globalization variable - TRADE (trade in goods). Control variables: GDP per capita (GDPPCAP), capital intensity (CAPSTOCK), economic growth (GROWTH), politics (DEMOCRACY), population share in higher education (POPSHARE), gross enrolment in higher education (PARTIC). 


\section{Hypothesis 2- Alternative measures of globalization}

Table 5

Multiple Regression Results: Higher education attainment (ATTAINP) and alternative globalization measure (FDI).

\begin{tabular}{|l|c|l|l|l|l|l|l|l|}
\hline Variable & $1970-$ & $1975-$ & $1980-$ & $1985-$ & $1990-$ & $1995-$ & $2000-$ & $2005-$ \\
& 74 & 79 & 84 & 89 & 94 & 99 & 04 & 09 \\
\hline FDI & - & .08 & -.15 & .10 & -.01 & .05 & .00 & .04 \\
\hline GDPPCAP & - & .37 & -.10 & .19 & .21 & $.30^{*}$ & $.34^{* *}$ & $.38^{* *}$ \\
\hline URBAN & - & .26 & $.33^{*}$ & .02 & $.28^{*}$ & $.34^{* *}$ & $.28^{*}$ & $.30^{*}$ \\
\hline CAPSTOCK & - & -.11 & .02 & -.25 & -.13 & -.05 & .01 & .03 \\
\hline SAL & - & $.38^{* *}$ & $.47^{* *}$ & $.52^{* *}$ & $.41^{* *}$ & .18 & .17 & .16 \\
\hline DEMOCRACY & - & -.06 & .17 & .19 & .08 & .15 & $.19^{*}$ & .11 \\
\hline TOTEDEXP & - & .00 & -.06 & -.19 & -.10 & -.12 & -.12 & -.09 \\
\hline$R^{2}$ & - & $.68^{* *}$ & $.54^{* *}$ & $.61 * *$ & $.65^{* *}$ & $.61^{* *}$ & $.61^{* *}$ & $.59^{* *}$ \\
\hline$N$ & - & 40 & 44 & 43 & 49 & 66 & 78 & 73 \\
\hline
\end{tabular}

Notes: ${ }^{*} p<.05 .{ }^{* *} p<.01 . R-$ correlation coefficient.. Standardized coefficients. Dependent variable:

ATTAINP - Percentage of population 15 years and over attaining education at the tertiary level.

Globalization variable - FDI (foreign direct investment). Control variables: GDPPCAP -GDP per capita, URBAN - urban population, CAPSTOCK - capital intensity, SAL -population attaining secondary (lagged), DEMOCRACY - popularly based government, TOTEDEXP - total education expenditure.

Table 6

Multiple Regression Results: Higher education attainment (ATTAINP) and alternative globalization measure (TRADE).

\begin{tabular}{|c|c|c|c|c|c|c|c|c|}
\hline Variable & $\begin{array}{l}1970- \\
74\end{array}$ & $\begin{array}{l}1975- \\
79\end{array}$ & $\begin{array}{l}1980- \\
84\end{array}$ & $\begin{array}{l}1985- \\
89\end{array}$ & $\begin{array}{l}1990- \\
94\end{array}$ & $\begin{array}{l}1995- \\
99\end{array}$ & $\begin{array}{l}2000- \\
04\end{array}$ & $\begin{array}{l}2005- \\
09\end{array}$ \\
\hline TRADE & - & -.12 & -.13 & -.08 & -.12 & .00 & -.07 & .03 \\
\hline GDPPCAP & - & .28 & -.12 & .06 & .27 & $.29 *$ & $.33 * *$ & $.37 * *$ \\
\hline URBAN & - & $.38 *$ & $.41 *$ & .18 & $.34 *$ & $.34 * *$ & $.28 *$ & $.31 *$ \\
\hline CAPSTOCK & - & .01 & .04 & -.16 & -.13 & -.05 & .03 & .03 \\
\hline SAL & - & $.35 * *$ & $.46^{* *}$ & $.52 * *$ & $.40 * *$ & .19 & .19 & .16 \\
\hline DEMOCRACY & - & -.07 & .12 & .16 & .09 & .17 & $.19 *$ & .11 \\
\hline TOTEDEXP & - & .03 & -.02 & -.11 & -.09 & -.11 & -.11 & -.09 \\
\hline$R^{2}$ & - & $.68 * *$ & $.52 * *$ & $.61 * *$ & $.66 * *$ & $.62 * *$ & $.61 * *$ & $.59 * *$ \\
\hline$N$ & - & 43 & 47 & 45 & 50 & 67 & 78 & 73 \\
\hline
\end{tabular}

Notes: ${ }^{*} p<.05 .{ }^{* *} p<.01 . R-$ correlation coefficient. Standardized coefficients. Dependent variable: ATTAINP - Percentage of population 15 years and over attaining education at the tertiary level. Globalization variable - TRADE (trade in goods). Control variables: GDPPCAP -GDP per capita, URBAN - urban population, CAPSTOCK - capital intensity, SAL - population attaining secondary (lagged), DEMOCRACY - popularly based government, TOTEDEXP - total education expenditure. 
Table 7

Multiple Regression Results: Higher education attainment (ATTAINY) and alternative globalization measure (FDI).

\begin{tabular}{|l|c|l|l|l|l|l|l|l|}
\hline Variable & $1970-$ & $1975-$ & $1980-$ & $1985-$ & $1990-$ & $1995-$ & $2000-$ & $2005-$ \\
& 74 & 79 & 84 & 89 & 94 & 99 & 04 & 09 \\
\hline FDI & - & .05 & -.16 & .07 & .01 & .05 & -.02 & -.00 \\
\hline GDPPCAP & - & .32 & -.08 & .16 & .27 & $.33^{* *}$ & $.36^{* *}$ & $.41^{* *}$ \\
\hline URBAN & - & .30 & $.36^{*}$ & .09 & $.30^{*}$ & $.38^{* *}$ & $.32^{* *}$ & $.39^{* *}$ \\
\hline CAPSTOCK & - & -.08 & .03 & -.25 & -.12 & -.01 & .02 & .07 \\
\hline SAL & - & $.40^{* *}$ & $.49^{* *}$ & $.54^{* *}$ & $.36^{* *}$ & .15 & .15 & .06 \\
\hline DEMOCRACY & - & -.04 & .10 & .14 & .06 & .11 & $.18^{*}$ & .11 \\
\hline TOTEDEXP & - & .04 & -.06 & -.16 & -.11 & -.08 & -.12 & -.08 \\
\hline$R^{2}$ & - & $.70^{* *}$ & $.57^{* *}$ & $.62^{* *}$ & $.65^{* *}$ & $.63^{* *}$ & $.64^{* *}$ & $.64^{* *}$ \\
\hline$N$ & - & 40 & 44 & 43 & 49 & 66 & 78 & 73 \\
\hline
\end{tabular}

Notes: ${ }^{*} p<.05 .{ }^{* *} p<.01$. Standardized coefficients. Dependent variable: ATTAINY -average years of tertiary schooling of the population. Globalization variable - FDI (foreign direct investment). Control variables: GDPPCAP -GDP per capita, URBAN - urban population, CAPSTOCK - capital intensity, DEMOCRACY - popularly based government, SAL - population attaining secondary (lagged),

TOTEDEXP - total education expenditure.

Table 8

Multiple Regression Results: Higher education attainment (ATTAINY) and alternative globalization measure (TRADE).

\begin{tabular}{|l|c|l|l|l|l|l|l|l|}
\hline Variable & $1970-$ & $1975-$ & $1980-$ & $1985-$ & $1990-$ & $1995-$ & $2000-$ & $2005-$ \\
& 74 & 79 & 84 & 89 & 94 & 99 & 04 & 09 \\
\hline TRADE & - & -.14 & -.17 & -.10 & -.19 & -.02 & -.09 & .03 \\
\hline GDPPCAP & - & .26 & -.07 & .07 & $.36^{*}$ & $.31^{*}$ & $.34^{* *}$ & $.41^{* *}$ \\
\hline URBAN & - & $.38^{*}$ & $.41^{* *}$ & .20 & $.35^{*}$ & $.37^{* *}$ & $.31^{* *}$ & $.39^{* *}$ \\
\hline CAPSTOCK & - & .02 & .05 & -.17 & -.12 & .00 & .04 & .06 \\
\hline SAL & - & $.39^{* *}$ & $.50^{* *}$ & $.54^{* *}$ & $.35^{* *}$ & .16 & .17 & .04 \\
\hline DEMOCRACY & - & -.06 & .06 & .12 & .09 & .14 & $.18^{*}$ & .12 \\
\hline TOTEDEXP & - & .05 & -.03 & -.11 & -.10 & -.06 & -.11 & -.08 \\
\hline$R^{2}$ & - & $.71^{* *}$ & $.57^{* *}$ & $.63^{* *}$ & $.67^{* *}$ & $.63^{* *}$ & $.65^{* *}$ & $.64^{* *}$ \\
\hline$N$ & - & 43 & 47 & 45 & 50 & 67 & 78 & 73 \\
\hline
\end{tabular}

Notes: ${ }^{*} p<.05 .{ }^{* *} p<.01$. Standardized coefficients. Dependent variable: ATTAINY -average years of tertiary schooling of the population. Globalization variable - KOF (index of globalization). Control variables: GDPPCAP -GDP per capita, URBAN - urban population, CAPSTOCK - capital intensity, DEMOCRACY - popularly based government, SAL - population attaining secondary (lagged), TOTEDEXP - total education expenditure. 
Table 9

Multiple Regression Results: Higher education participation (PARTIC) and alternative globalization measure (FDI).

\begin{tabular}{|l|c|l|l|l|l|l|l|l|}
\hline Variable & $1970-$ & $1975-$ & $1980-$ & $1985-$ & $1990-$ & $1995-$ & $2000-$ & $2005-$ \\
& 74 & 79 & 84 & 89 & 94 & 99 & 04 & 09 \\
\hline FDI & - & .12 & -.07 & .02 & -.11 & -.02 & -.07 & -.09 \\
\hline GDPPCAP & - & .44 & .17 & .25 & $.29 *$ & $.26^{*}$ & .16 & .10 \\
\hline URBAN & - & $.38^{* *}$ & $.48^{* *}$ & .09 & .10 & $.20^{*}$ & $.31^{* *}$ & $.30^{*}$ \\
\hline CAPSTOCK & - & -.01 & .06 & -.15 & -.08 & -.03 & .09 & -.01 \\
\hline SGERL & - & .19 & .29 & $.48^{*}$ & $.44 * *$ & $.42^{* *}$ & $.40^{* *}$ & $.50^{* *}$ \\
\hline DEMOCRACY & - & .01 & -.03 & .04 & .09 & $.17^{*}$ & $.20^{* *}$ & .02 \\
\hline TOTEDEXP & - & -.05 & -.00 & -.13 & -.00 & -.02 & .04 & .12 \\
\hline$R^{2}$ & - & $.84 * *$ & $.72 * *$ & $.62^{* *}$ & $.70^{* *}$ & $.79^{* *}$ & $.80^{* *}$ & $.76^{* *}$ \\
\hline$N$ & - & 38 & 42 & 42 & 48 & 61 & 77 & 77 \\
\hline
\end{tabular}

Notes: ${ }^{*} p<.05 .{ }^{* *} p<.01$. Standardized coefficients. Dependent variable: PARTIC - gross enrollment ratio in higher education. Globalization variable- FDI (foreign direct investment). Control variables: GDPPCAP -GDP per capita, URBAN - urban population, CAPSTOCK - capital intensity, DEMOCRACY - popularly based government, SGERL - gross enrollment ratio secondary (lagged), TOTEDEXP - total education expenditure.

Table 10

Multiple Regression Results: Higher education participation (PARTIC) and alternative globalization measure (TRADE).

\begin{tabular}{|l|c|l|l|l|l|l|l|l|}
\hline Variable & $1970-$ & $1975-$ & $1980-$ & $1985-$ & $1990-$ & $1995-$ & $2000-$ & $2005-$ \\
& 74 & 79 & 84 & 89 & 94 & 99 & 04 & 09 \\
\hline TRADE & - & -.08 & -.00 & -.20 & .21 & -.09 & $-.12^{*}$ & -.09 \\
\hline GDPPCAP & - & $.52^{*}$ & .31 & .16 & .23 & $.22^{*}$ & .12 & .11 \\
\hline URBAN & - & $.32^{*}$ & $.49^{*}$ & .09 & .09 & $.21 *$ & $.30^{* *}$ & $.25^{*}$ \\
\hline CAPSTOCK & - & .04 & .05 & -.19 & -.09 & .01 & .09 & -.02 \\
\hline SGERL & - & .14 & .16 & $.60^{* *}$ & $.37 *$ & $.42^{* *}$ & $.44^{* *}$ & $.54^{* *}$ \\
\hline DEMOCRACY & - & -.03 & -.02 & .03 & .04 & $.19^{*}$ & $.20^{* *}$ & .00 \\
\hline TOTEDEXP & - & -.04 & -.04 & -.07 & -.01 & .01 & .06 & .12 \\
\hline$R^{2}$ & - & $.84 * *$ & $.71 * *$ & $.66^{* *}$ & $.71^{* *}$ & $.80^{* *}$ & $.81^{* *}$ & $.76^{* *}$ \\
\hline$N$ & - & 41 & 45 & 45 & 49 & 62 & 77 & 77 \\
\hline
\end{tabular}

Notes: $* p<.05 .{ }^{* *} p<.01$. Standardized coefficients. Dependent variable: PARTIC - gross enrollment ratio in higher education. Globalization variable - TRADE (trade in goods). Control variables: GDPPCAP GDP per capita, URBAN - urban population, CAPSTOCK - capital intensity, DEMOCRACY - popularly based government, SGERL - gross enrollment ratio secondary (lagged), TOTEDEXP - total education expenditure. 
Table 11

Multiple Regression Results: Higher education equity (GENEQUC) and alternative globalization measure (FDI).

\begin{tabular}{|l|c|l|l|l|l|l|l|l|}
\hline Variable & 1970 & $1975-$ & $1980-$ & $1985-$ & $1990-$ & $1995-$ & $\begin{array}{l}2000- \\
04\end{array}$ & $\begin{array}{l}2005- \\
09\end{array}$ \\
\hline FDI & -74 & 79 & 84 & 89 & 94 & 99 & 04 \\
\hline GDPPCAP & - & -.04 & -.03 & .26 & $.55^{* *}$ & .15 & -.02 & -.11 \\
\hline URBAN & - & .42 & -.48 & -.43 & .21 & -.19 & -.25 & $-.34^{*}$ \\
\hline CAPSTOCK & - & .12 & .10 & -.29 & $-.34^{*}$ & .12 & .20 & .056 \\
\hline SAL & - & .22 & .30 & .25 & .12 & .04 & -.10 & .07 \\
\hline DEMOCRACY & - & .29 & .01 & $.44^{*}$ & -.31 & .06 & .14 & .20 \\
\hline TOTEDEXP & - & -.13 & $-.25^{*}$ & -.25 & -.17 & -.00 & .23 & .17 \\
\hline$R^{2}$ & - & .31 & .31 & $.44^{* *}$ & $.33^{*}$ & $.28^{* *}$ & .18 & $.26^{* *}$ \\
\hline$N$ & - & 40 & 44 & 43 & 49 & 66 & 78 & 72 \\
\hline
\end{tabular}

Notes: ${ }^{*} p<.05 .{ }^{* *} p<.01$. Standardized coefficients. Dependent variable: GENEQUC - ratio of females to males completing higher education. Globalization variable - FDI (foreign direct investment). Control variables: GDPPCAP -GDP per capita, URBAN - urban population, CAPSTOCK - capital intensity, DEMOCRACY - popularly based government, SAL - population attaining secondary (lagged),

TOTEDEXP - total education expenditure.

Table 12

Multiple Regression Results: Higher education equity (GENEQUC) and alternative globalization measure (TRADE).

\begin{tabular}{|l|c|l|l|l|l|l|l|l|}
\hline Variable & $1970-$ & $1975-$ & $1980-$ & $1985-$ & $1990-$ & $1995-$ & $2000-$ & $2005-$ \\
& 74 & 79 & 84 & 89 & 94 & 99 & 04 & 09 \\
\hline TRADE & - & -.16 & -.02 & $.34^{*}$ & .08 & .15 & .17 & .14 \\
\hline GDPPCAP & - & -.44 & -.48 & -.42 & -.01 & .19 & -.21 & -.30 \\
\hline URBAN & - & $.49^{*}$ & $.46^{*}$ & .15 & -.05 & $.53^{* *}$ & $.40^{*}$ & $.53^{* *}$ \\
\hline CAPSTOCK & - & .19 & .10 & -.23 & -.22 & .08 & .14 & .00 \\
\hline SAL & - & .22 & .30 & .20 & .19 & .04 & -.15 & -.02 \\
\hline DEMOCRACY & - & .29 & .01 & $.49^{* *}$ & -.24 & .09 & .13 & .20 \\
\hline TOTEDEXP & - & -.13 & -.25 & $-.31^{*}$ & -.15 & -.02 & .20 & .13 \\
\hline$R^{2}$ & - & $.32^{*}$ & $.31^{*}$ & $.47^{* *}$ & .07 & $.28^{* *}$ & $.20^{*}$ & $.27 * *$ \\
\hline$N$ & - & 43 & 47 & 45 & 50 & 67 & 78 & 72 \\
\hline
\end{tabular}

Notes: ${ }^{*} p<.05 .{ }^{* *} p<.01$. Standardized coefficients. Dependent variable: GENEQUC - ratio of females to males completing higher education. Globalization variable - FDI (foreign direct investment). Control variables: GDPPCAP -GDP per capita, URBAN - urban population, CAPSTOCK - capital intensity, DEMOCRACY - popularly based government, SAL - population attaining secondary (lagged),

TOTEDEXP - total education expenditure. 
Table 13

Multiple Regression Results: Higher education equity (GENEQUGER) and alternative globalization measure (FDI).

\begin{tabular}{|l|l|l|l|l|l|l|l|l|}
\hline Variable & \multicolumn{1}{l}{$1970-$} & $1975-$ & $1980-$ & $1985-$ & $1990-$ & $1995-$ & $2000-$ & $2005-$ \\
& 74 & 79 & 84 & 89 & 94 & 99 & 04 & 09 \\
\hline FDI & - & -.05 & -.36 & .10 & .04 & -.03 & -.14 & .11 \\
\hline GDPPCAP & - & -.16 & -.57 & -.02 & -.17 & $-.46^{*}$ & -.18 & .04 \\
\hline URBAN & - & -.08 & .35 & .06 & -.33 & .19 & -.00 & -.09 \\
\hline CAPSTOCK & - & .11 & -.04 & .01 & -.02 & -.01 & -.12 & -.08 \\
\hline SGERL & - & .63 & .80 & .06 & $1.06^{*}$ & .46 & .41 & .39 \\
\hline DEMOCRACY & - & -.22 & -.26 & .51 & -.14 & .29 & .17 & -.01 \\
\hline TOTEDEXP & - & -.36 & -.11 & -.32 & .12 & .18 & -.06 & -.02 \\
\hline$R^{2}$ & - & .28 & .42 & .48 & $.50 * *$ & $.33^{* *}$ & $.22^{*}$ & .15 \\
\hline$N$ & - & 30 & 28 & 26 & 31 & 49 & 64 & 67 \\
\hline
\end{tabular}

Notes: ${ }^{*} p<.05 .{ }^{* *} p<.01$. Standardized coefficients. Dependent variable: GENEQUGER - Ratio of females to males completing higher education. Globalization variable - FDI (foreign direct investment). Control variables: GDPPCAP -GDP per capita, URBAN - urban population, CAPSTOCK -capital intensity, DEMOCRACY - popularly based government, SGERL - gross enrollment ratio secondary (lagged), TOTEDEXP - total education expenditure.

Table 14

Multiple Regression Results: Higher education equity (GENEQUGER) and alternative globalization measure (TRADE).

\begin{tabular}{|c|c|c|c|c|c|c|c|c|}
\hline Variable & $\begin{array}{l}1970- \\
74\end{array}$ & $\begin{array}{l}1975- \\
79\end{array}$ & $\begin{array}{l}1980- \\
84\end{array}$ & $\begin{array}{l}1985- \\
89\end{array}$ & $\begin{array}{l}1990- \\
94\end{array}$ & $\begin{array}{l}1995- \\
99\end{array}$ & $\begin{array}{l}2000- \\
04\end{array}$ & $\begin{array}{l}2005- \\
09\end{array}$ \\
\hline TRADE & - & .01 & -.27 & -.21 & -.25 & -.07 & .25 & .04 \\
\hline GDPPCAP & - & -.06 & -.64 & -.42 & -.08 & $-.49 *$ & -.13 & .01 \\
\hline URBAN & - & .10 & .35 & .18 & -.25 & .19 & .01 & -.06 \\
\hline CAPSTOCK & - & .04 & -.04 & .11 & -.03 & .01 & -.22 & -.06 \\
\hline SGERL & - & .38 & $.92 *$ & .62 & $1.09 * *$ & .48 & .34 & .40 \\
\hline DEMOCRACY & - & -.14 & -.22 & .19 & -.11 & .30 & .13 & .02 \\
\hline TOTEDEXP & - & -.32 & .07 & -.15 & .12 & .20 & -.09 & -.01 \\
\hline$\overline{R^{2}}$ & - & .27 & $.49^{*}$ & $.51 *$ & $.52 * *$ & $.33^{*}$ & $.26^{*}$ & .14 \\
\hline$N$ & - & 33 & 31 & 29 & 32 & 50 & 64 & 67 \\
\hline
\end{tabular}

Notes: ${ }^{*} p<.05 .{ }^{* *} p<.01$. Standardized coefficients. Dependent variable: GENEQUGER - Ratio of females to males completing higher education. Globalization variable - TRADE (trade in goods). Control variables: GDPPCAP -GDP per capita, URBAN - urban population, CAPSTOCK - capital intensity, DEMOCRACY - popularly based government, SGERL - gross enrollment ratio secondary (lagged), TOTEDEXP - total education expenditure. 
VITA

\section{CLAUDETTE NYANG'ORO NÉE JOHNSON}

Born: Scarborough, Tobago (Trinidad and Tobago)

1991

$1993-1995$

1996

$1996-1997$

2000

$2000-2010$
Bachelor of Science. Economics.

University of the West Indies,

St. Augustine, Trinidad

Business Analyst.

Ministry of Finance, Trinidad.

Master of Science. Economics.

University of the West Indies,

St. Augustine, Trinidad.

Consultant Economist.

Inter-American Institute for Cooperation on Agriculture, Trinidad.

Master of Business Administration.

Florida International University,

Miami, Florida.

Instructor, Florida National University

Hialeah, Florida

\section{PUBLICATIONS}

Johnson, Claudette. "The Economic Contribution of Education in a Post-Colonial Society: The Case of Trinidad and Tobago, 1966 to 1992." Master's thesis, University of the West Indies, 1996.

Johnson, Claudette \& Antoine, Patrick A. (1997). A Review of the Macro-Economic Policy Environment of the OECS: 1980-1995. IICA Biblioteca Venezuela. 